\title{
Demonstrating a Market-Based Approach to the Reclamation of Mined Lands in West Virginia
}

Final Technical Report

Report Period:

Stop Date: December 31, 2009

Start Date: October 1, 2003

John W. Goodrich-Mahoney

Ellen Donnelly

DE-FC26-03NT41899

Electric Power Research Institute 3240 Hillview Avenue

Palo Alto, CA 94304 


\section{DISCLAIMER OF WARRANTIES AND LIMITATION OF LIABILITIES}

"THIS REPORT WAS PREPARED AS AN ACCOUNT OF WORK SPONSORED BY AN AGENCY OF THE UNITED STATES GOVERNMENT. NEITHER THE UNITED STATES GOVERNMENT NOR ANY AGENCY THEREOF, NOR ANY OF THEIR EMPLOYEES, MAKES ANY WARRANTY, EXPRESS OR IMPLIED, OR ASSUMES ANY LEGAL LIABILITY OR RESPONSIBILITY FOR THE ACCURACY, COMPLETENESS, OR USEFULNESS OF ANY INFORMATION, APPARATUS, PRODUCT, OR PROCESS DISCLOSED, OR REPRESENTS THAT ITS USE WOULD NOT INFRINGE PRIVATELY OWNED RIGHTS. REFERENCE HEREIN TO ANY SPECIFIC COMMERCIAL PRODUCT, PROCESS, OR SERVICE BY TRADE NAME, TRADEMARK, MANUFACTURER, OR OTHERWISE DOES NOT NECESSARILY CONSTITUTE OR IMPLY ITS ENDORSEMENT, RECOMMENDATION, OR FAVORING BY THE UNITED STATES GOVERNMENT OR ANY AGENCY THEREOF. THE VIEWS AND OPINIONS OF AUTHORS EXPRESSED HEREIN DO NOT NECESSARILY STATE OR REFLECT THOSE OF THE UNITED STATES GOVERNMENT OR ANY AGENCY THEREOF."

THIS DOCUMENT WAS PREPARED BY THE ORGANIZATION(S) NAMED BELOW AS AN ACCOUNT OF WORK SPONSORED OR COSPONSORED BY THE ELECTRIC POWER RESEARCH INSTITUTE, INC. (EPRI). NEITHER EPRI, ANY MEMBER OF EPRI, ANY COSPONSOR, THE ORGANIZATION(S) BELOW, NOR ANY PERSON ACTING ON BEHALF OF ANY OF THEM:

(A) MAKES ANY WARRANTY OR REPRESENTATION WHATSOEVER, EXPRESS OR IMPLIED, (I) WITH RESPECT TO THE USE OF ANY INFORMATION, APPARATUS, METHOD, PROCESS, OR SIMILAR ITEM DISCLOSED IN THIS DOCUMENT, INCLUDING MERCHANTABILITY AND FITNESS FOR A PARTICULAR PURPOSE, OR (II) THAT SUCH USE DOES NOT INFRINGE ON OR INTERFERE WITH PRIVATELY OWNED RIGHTS, INCLUDING ANY PARTY'S INTELLECTUAL PROPERTY, OR (III) THAT THIS DOCUMENT IS SUITABLE TO ANY PARTICULAR USER'S CIRCUMSTANCE; OR

(B) ASSUMES RESPONSIBILITY FOR ANY DAMAGES OR OTHER LIABILITY WHATSOEVER (INCLUDING ANY CONSEQUENTIAL DAMAGES, EVEN IF EPRI OR ANY EPRI REPRESENTATIVE HAS BEEN ADVISED OF THE POSSIBILITY OF SUCH DAMAGES) RESULTING FROM YOUR SELECTION OR USE OF THIS DOCUMENT OR ANY INFORMATION, APPARATUS, METHOD, PROCESS, OR SIMILAR ITEM DISCLOSED IN THIS DOCUMENT.

ORGANIZATION(S) THAT PREPARED THIS DOCUMENT

Ellen Donnelly, dba Donnelly Communications 


\section{ABSTRACT}

This project demonstrated that developing environmental credits on private land-including abandoned mined lands - is dependent on a number of factors, some of them beyond the control of the project team. In this project, acid mine drainage (AMD) was successfully remediated through the construction of a passive AMD treatment system. Extensive water quality sampling both before and after the installation of the passive AMD treatment system showed that the system achieved removal efficiencies and pollutant loading reductions for acidity, iron, aluminum and manganese that were consistent with systems of similar size and design. The success of the passive AMD treatment system should have resulted in water credits if the project had not been terminated. Developing carbon sequestration credits, however, was much more complex and was not achieved in this project.

The primary challenge that the project team encountered in meeting the full project objectives was the unsuccessful attempt to have the landowner sign a conservation easement for his property. This would have allowed the project team to clear and reforest the site, monitor the progress of the newly planted trees, and eventually realize carbon sequestration credits once the forest was mature. The delays caused by the lack of a conservation easement, as well as other factors, eventually resulted in the reforestation portion of the project being cancelled.

The information in this report will help the public make more informed decisions regarding the potential of using water and carbon, and other credits to support the remediation of minded lands through out the United States. The hope is that by using credits that more mined lands with be remediated. 
For further information about EPRI, call the EPRI Customer Assistance Center at 800.313.3774 or e-mail askepri@epri.com.

Electric Power Research Institute, EPRI, and TOGETHER...SHAPING THE FUTURE OF ELECTRICITY are registered service marks of the Electric Power Research Institute, Inc. 


\section{CITATIONS}

This report was prepared by

Ellen Donnelly dba Donnelly Communications

96 Amesport Landing

Half Moon Bay, CA 94019

Principal Investigator

E. Donnelly

This report describes research sponsored by the Electric Power Research Institute (EPRI).

This publication is a corporate document that should be cited in the literature in the following manner:

Demonstrating a Market-Based Approach to the Reclamation of Mined Lands in West Virginia. EPRI, Palo Alto, CA: 2009. 



\section{PRODUCT DESCRIPTION}

This report discusses a project designed to develop water and carbon sequestration credits on an abandoned mined land site. The project was funded by the Department of Energy and EPRI in order to support the development and use of multiple environmental credit markets to support private investment in abandoned mined lands restoration.

\section{Results and Findings}

This project demonstrated that developing environmental credits on private land-including abandoned mined lands - is dependent on a number of factors, some of them beyond the control of the project team. In this project, acid mine drainage (AMD) was successfully remediated through the construction of a passive AMD treatment system. Extensive water quality sampling both before and after the installation of the passive AMD treatment system showed that the system achieved removal efficiencies and pollutant loading reductions for acidity, iron, aluminum and manganese that were consistent with systems of similar size and design. The success of the passive AMD treatment system should have resulted in water credits if the project had not been terminated. Developing carbon sequestration credits, however, was much more complex and was not achieved in this project.

\section{Challenges and Objectives}

The primary challenge that the project team encountered in meeting the project objectives was the unsuccessful attempt to have the landowner sign a conservation easement for his property. This would have allowed the project team to clear and reforest the site, monitor the progress of the newly planted trees, and eventually realize carbon sequestration credits once the forest was mature. The delays caused by the lack of a conservation easement, as well as cost overruns and weather delays, eventually resulted in the reforestation portion of the project being cancelled. In addition, it should be noted that in most projects of this type, the landowner or some other entity will have to incur all of the upfront costs of remediating and restoring the site before any environmental credits can be claimed.

\section{Applications, Values, and Use}

The information in this report will help the public make more informed decisions regarding the potential of using water and carbon, and other credits to support the remediation of minded lands through out the United States. The hope is that by using credits that more mined lands with be remediated. 


\section{EPRI Perspective}

This project demonstrates that despite the challenges involved in this type of project, restoring abandoned mined lands or other sites to develop water and/or carbon sequestration credits is possible if a number of criteria are met. These criteria include finding an appropriate site, obtaining a conservation easement from the landowner, and accurately assessing the costs involved.

\section{Approach}

The goals of this report were to document the process involved in developing water and carbon sequestration credits on abandoned mined land, and accordingly discusses the successes and challenges of the project.

\section{Keywords}

Environmental credits

Abandoned mined lands

Water quality

Acid mine drainage

Carbon sequestration

Coal combustion products

Fly ash 


\section{ABBREVIATIONS}

$\begin{array}{ll}\text { ALD } & \text { Anoxic limestone drains } \\ \text { AMD } & \text { Acid mine drainage } \\ \text { AML } & \text { Abandoned mined lands } \\ \text { ART } & \text { Alkaline recharge trench } \\ \text { CCPs } & \text { Coal combustion products } \\ \text { LFD } & \text { Limestone foundation drain } \\ \text { NMLRC } & \text { National Mine Land Reclamation Center } \\ \text { NPDES } & \text { National Pollutant Discharge Elimination System } \\ \text { OLC } & \text { Open limestone channel } \\ \text { TMDL } & \text { Total maximum daily load } \\ \text { WVDEP } & \text { West Virginia Department of Environmental Protection } \\ \text { WVU } & \text { West Virginia University }\end{array}$





\section{TABLE OF CONTENTS}

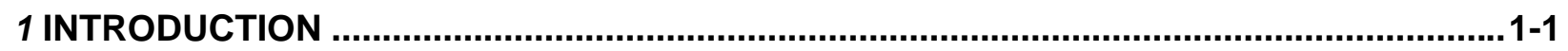

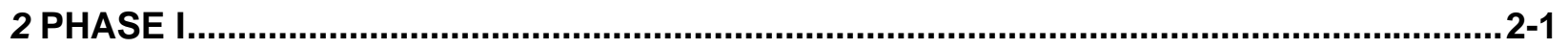

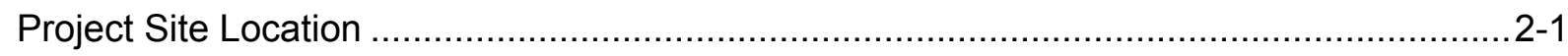

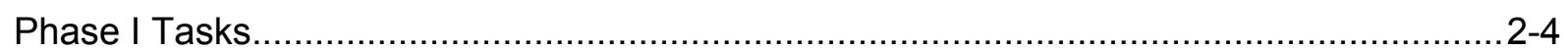

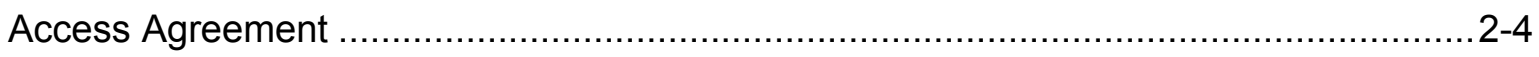

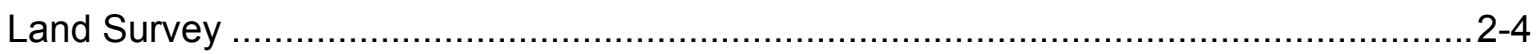

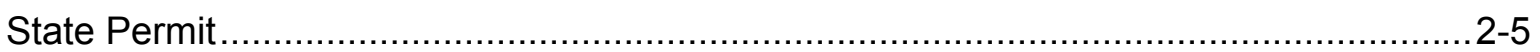

Soil and Water Quality Sampling ........................................................................ 2-5

Fly Ash Chemistry: Allegheny Energy's Albright Power Plant ....................................2-14

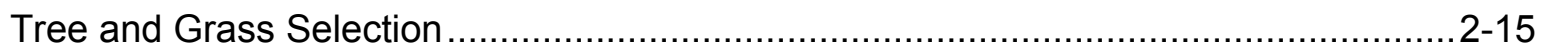

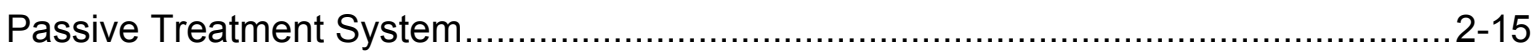

Site Construction Bid Package ............................................................................

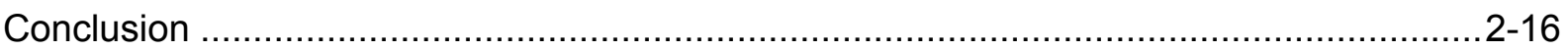

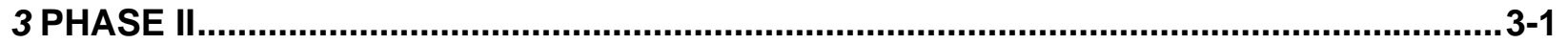

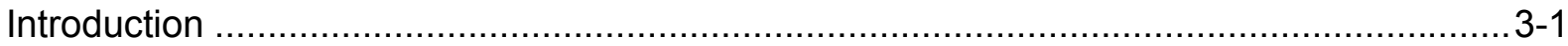

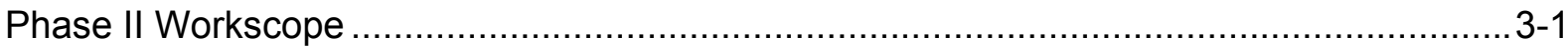

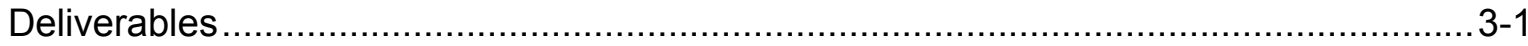

Detailed Description of Phase II Tasks ……………............................................... 3-1

Task 1: Passive AMD Treatment System for Reclamation of AMD Affected

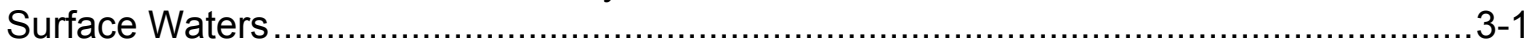

AMD Treatment Site Evaluation and Identification of Treatment Alternatives .............3-3

Phase I: Watershed Evaluation ......................................................................

Phase II: Site Evaluation ............................................................................

Phase III: Identify Treatment Needs.............................................................. 3-5

Phase IV: Treatment Technology Selection ...................................................

Critical Parameters in Watershed Planning and Remediation ................................3-6

AMD Passive Treatment System Moved from Sovern Run to Connor Run................3-10 
Baseline Water Quality Monitoring on Connor Run ........................................ $3-12$

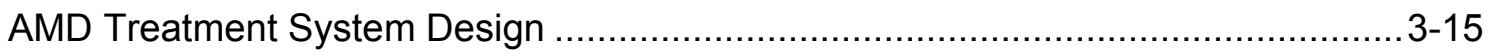

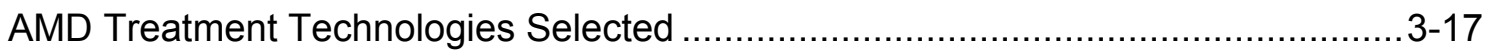

Passive Treatment System Components.................................................. $3-18$

Alkaline Recharge Trench .................................................................. $3-18$

Open Limestone Channel .................................................................. $3-19$

Limestone Foundation Drain .............................................................. $3-20$

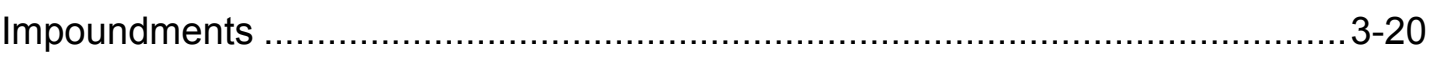

Construction of the AMD Passive Treatment System............................................. $3-20$

Task 2: Reforest and Enhance Carbon Sequestration Project Site ............................ 3-26

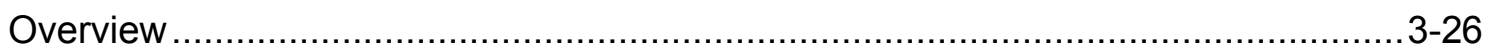

Building An Access Road for Transporting Ash ............................................. $3-27$

Analyzing and Preparing the Soil for Ash Amendment ..................................... $3-28$

Clearing and Reforesting the Project Site................................................. $3-29$

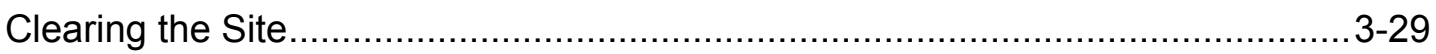

Reforesting the Site......................................................................... 30

Performance of Hardwood Seedlings ...................................................... 3-31

Measure Carbon Soil and Vegetative Matter Content.....................................3-31

Task 3: Quantify Water Quality and Carbon Sequestration Credits ..............................3-32

Performance of the AMD Passive Treatment System ......................................... $3-32$

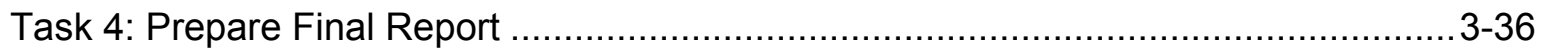

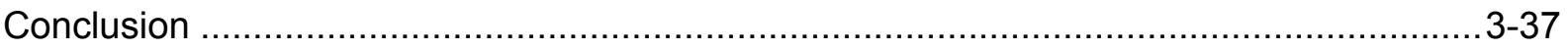

4 PHASE III.................................................................................................................... 4-1

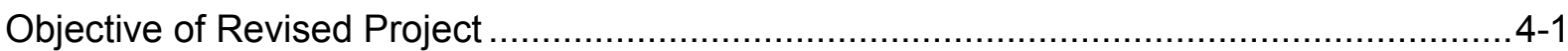

Revised Scope of Work and Timeline .................................................................... 4-2

Task 1: Quarterly Reports ............................................................................... $4-2$

Task 2: Continue Monitoring the Passive Treatment System Performance ....................4-2

Task 3: Literature Search to Establish the Status of Environmental Credit Markets ........4-2

Task 4: Develop Decision Trees............................................................................. $4-2$

Task 5: Develop Spreadsheet Model ................................................................... 4-3

Task 6: Prepare Final Report .............................................................................. $4-4$

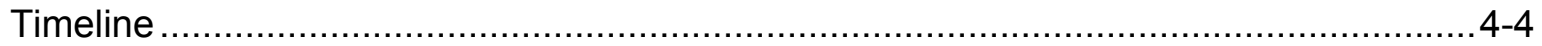

Phase III Cost Proposal from West Virginia University ............................................... 4-4

Project Workscope Shifts from West Virginia University to EPRI..................................4-4 


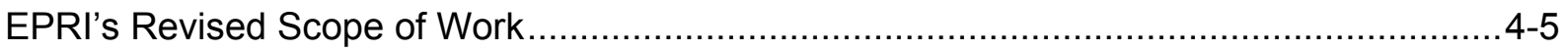

Final Stage of the Project....................................................................................

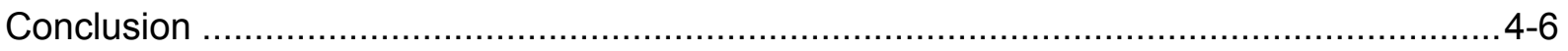

5 SUMMARY AND CONCLUSIONS .............................................................................. 5-1

Remediating Acid Mine Drainage to Capture Future Water Credits.................................5-1

Reforesting a Site to Capture Future Carbon Credits ..................................................... 5-2

Obtaining a Conservation Easement.................................................................... $5-2$

Using Fly Ash as a Soil Amendment ................................................................

Weather and Cost Challenges........................................................................

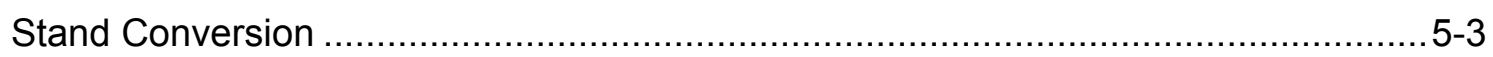

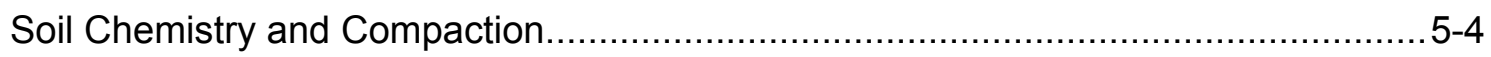

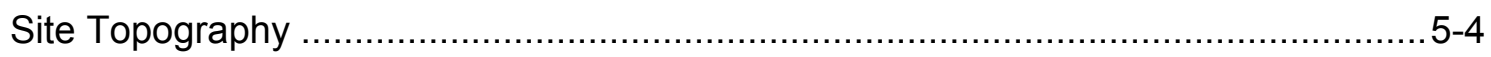

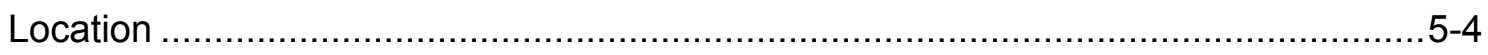

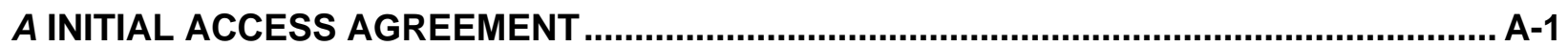

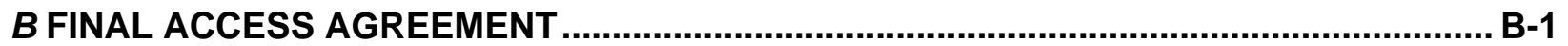

C PROCESS FOR CALCULATING AMOUNT OF ASH NEEDED TO NEUTRALIZE

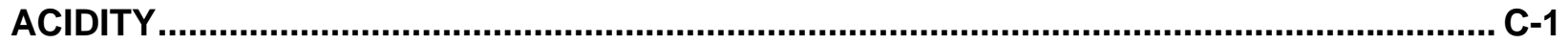

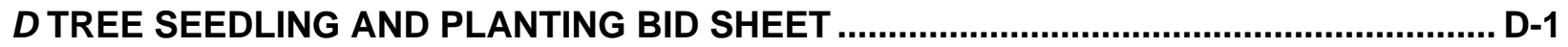

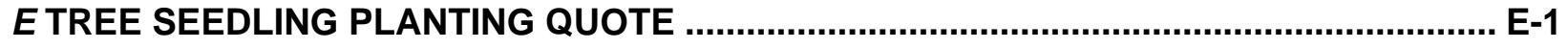

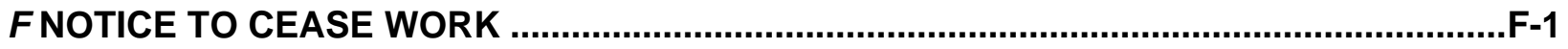

G STORM WATER PERMIT NOTICE OF TERMINATION .................................................. G-1

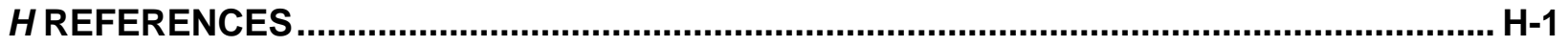





\section{LIST OF FIGURES}

Figure 2-1 Project Location Map Depicting Sovern Run and Connor Run AMD

Discharges, Proposed Passive Treatment System and Reforestation Sites.

Figure 2-2 Photo of Reforestation Site Prior to Clearing and Grubbing

Figure 2-3 Photo of AMD Connor Run Seep Emanating from the Base of Surface Mine

Spoil

Figure 3-1 pH Change with Increasing Investment in Acid Load Reductions

Figure 3-2 Photo of AMD Connor Run Seep Emanating from the Base of Surface Mine Spoil .....

Figure 3-3 AMD Contaminated Pond in Connor Run Drainage

Figure 3-4 Sample Locations for the Connor Run Site

Figure 3-5 Conceptual Design for Passive Treatment System on Connor Run

Figure 3-6 Alkaline Recharge Trench (ART) Cross Section

Figure 3-7 Schematic Depicting Final Passive AMD Treatment

Figure 3-8 Backhoe Breaching Dike of Former Sedimentation Pond

Figure 3-9 Backfilling and Compacting Sedimentation Pond

Figure 3-10 Construction and Compaction of Impoundment B Dike

Figure 3-11 Location of Impoundment A and ART

Figure 3-12 Backfilled Sediment Pond and Open Limestone Channel

Figure 3-13 Completed Impoundment B and OLC Conveying AMD from Former Pond

Figure 3-14 AMD Discharge from Impoundment A Showing Fe and Al Precipitation

Figure 3-15 Partially Constructed Access Road to Reforestation Site. 



\section{LIST OF TABLES}

Table 2-1 Soil Neutralization Potential and Paste $\mathrm{pH}$.................................................. 2-6

Table 2-2 Carbon Content of Living Vegetation .................................................................. 2-7

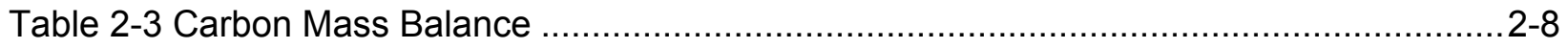

Table 2-4 Water Quality Sampling Data of Acid Mine Drainage .......................................2-9

Table 3-1 EPA and Standard Methods (2) Used for Analyzing Water Quality Samples ............3-3

Table 3-2 Decision Document for Determining Proper AMD Treatment ............................... 3-5

Table 3-3 Common Alkaline Amendments ........................................................................

Table 3-4 March, 2004 Water Quality Analysis Results for Connor Run Drainages................3-13

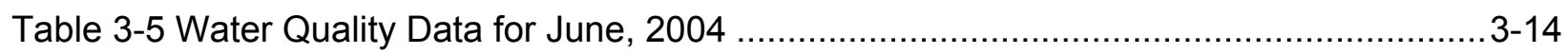

Table 3-6 Water Quality Data_July and September, 2004 ............................................. 3-15

Table 3-7 Baseline Parameters Used in Conceptual Design/Sizing of Passive Treatment

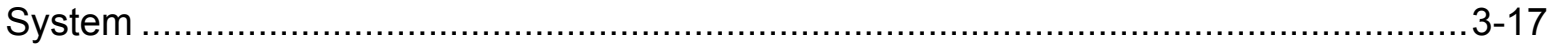

Table 3-8 As Built Dimensions and Costs for Passive Treatment System .........................3-26

Table 3-9 Calculation Used to Determine Fly Ash Necessary for Soil Amendment.................3-29

Table 3-10 Calculated Loading Reductions Resulting from Treatment (t/yr) ......................3-32

Table 3-11 Passive Treatment System Monitoring Results_Pre- and Post-Construction ......3-33

Table 3-12 Passive Treatment System Monitoring Results: April-June, 2005 .......................3-34

Table 3-13 Passive Treatment System Monitoring Results for July-September, 2005...........3-35

Table 3-14 Passive Treatment System Monitoring Results-October-December, 2005 .........3-35

Table 3-15 Passive Treatment System Monitoring Results for January-March, 2006 .............3-36 



\section{1 \\ INTRODUCTION}

The objective of this project was to demonstrate and evaluate the efficacy of developing multiple environmental market credits on mined lands as an economic incentive to encourage landowners and/or third parties to invest in more and enhanced mined land reclamation. There is increasing recognition by public and private sectors that market-based or incentive-based programs can supplement traditional prescriptive regulatory programs to accomplish greater pollutant reductions at less cost. The sulfur dioxide $\left(\mathrm{SO}_{2}\right)$ and nitrous oxide $\left(\mathrm{NO}_{\mathrm{X}}\right)$ cap and trade programs under the Clean Air Act are successful examples of such programs. Environmental commodity trading markets such as carbon sequestration, conservation banking, wetland banking and water quality credit trading are emerging at the international, national and state levels as market-based mechanisms to address climate change, protect threatened and endangered species, prevent wetland loss and encourage watershed restoration more quickly and at less cost. In contrast to traditional command-and-control regulatory approaches, federal agencies are shifting to incentive-based structures where landowners are rewarded for activities that support vital ecosystem services such as clean air and water, and healthy and diverse habitat.

This project is the outcome of a 2000 Memorandum of Understanding between the Department of Interior, Office of Surface Mining (OSM) and the Department of Energy (DOE) that supports the development and use of multiple environmental credit markets to encourage private investment in abandoned mine lands (AML) restoration. Many believe a market-based approach has the potential to promote innovative AML restoration, new technology and more ecologically holistic restoration at significantly less public cost.

While a federal or state regulatory agency determines the rules of the market/market structure, supply and demand forces determine the price. Credits can be used or sold in order to comply with mitigation requirements of federal statutes such as the Clean Air Act, Clean Water Act and Endangered Species Act or with state/watershed level water quality trading programs.

Concern over the increasing level of atmospheric carbon dioxide $\left(\mathrm{CO}_{2}\right)$ and its effect on climate has resulted in the development of carbon sequestration commodity markets both in the United States and abroad. At least 160 nations have already signed on to the global warming treaty called the Kyoto Protocol while others are taking different approaches to minimize greenhouse gases thought to cause the phenomenon. The Kyoto Protocol has resulted in a European Union mandatory greenhouse gas reduction program, which has spurred a dynamic $\mathrm{CO}_{2}$ cap and trade program with carbon credits selling for over $\$ 25.00 /$ ton. Although the market in the United States remains voluntary, seven Northeast states have formed the so-called Regional Greenhouse Gas Initiative that will implement a cap-and-trade program to lower $\mathrm{CO}_{2}$ emissions. In the meantime, many proactive corporations, in anticipation of a federal greenhouse gas regulatory control program, are investing in carbon sequestration projects to reduce their potential financial 
exposure when and if a carbon cap and trade program is promulgated. Several electric utilities, for example, helped design the Chicago Climate Exchange while a handful of power companies are participating in the U.S. Environmental Protection Agency’s (EPA) Climate Leaders Program.

Conservation banking, with about 75 endangered species banks, is growing allowing private landowners to sell species credits in exchange for developing or protecting key species' habitats. Habitats that support rare plant and animal species are selling for up to \$125,000/acre. In contrast, wetland mitigation banking is relatively well developed with over 300 banks selling credits for anywhere from \$5,000 to $\$ 250,000$ per acre depending on the local or watershed market demand.

With respect to water quality trading, the EPA released a policy in January, 2003 that encourages states to develop trading programs that are intended to help restore impaired waters at less cost. A number of state and watershed-based water quality trading programs are operating across the country with many more under development and consideration. Although most of the existing trading programs have thus far been limited to nutrients and sediment there is a clear need for development and implementation of programs to address other pollutants especially those associated with acid mine drainage (AMD). A framework for such an AMD trading program has been developed in the Cheat River watershed by a diverse group of stakeholders and awaits support from West Virginia Department of Environmental Protection (WVDEP) for implementation.

In Appalachia, the vast majority of land that is surface mined is forested. Laws originally passed in Ohio, Pennsylvania, and West Virginia, during the 1940s and 1950s, were designed to reclaim these disturbed forested lands by backfilling and replanting trees and shrubs. During ensuing decades and by 1977, laws and regulations governing surface mine reclamation in the eastern U.S. evolved into seeding grasses and legumes rather than establishing trees. The rationale for this change was that grasses and legumes quickly stabilized the soil reducing erosion, provided a quick economic return to land owners through haying or grazing of livestock, and was aesthetically pleasing. The outcome of these recent laws generally hindered tree planting because they permitted partial release of reclamation bonds as soon as the ground cover requirement was met. Under this framework reforestation was an added reclamation expense.

In response to some of the post-mining land use concerns of large scale surface mining, the West Virginia legislature in 2000 required re-establishment of commercial forest trees on surface coal mines, and especially on those sites where mountaintop removal mining has occurred. The reforestation policies specify replacement of the upper four feet of soil on the surface and also require minimal compaction during placement of this material.

Where acid generating geological formations were mined, reclaimed mines after 10 to 20 years often revert to low-productivity savannas with the understory dominated by acid tolerant native grasses and forbs and an over story consisting of Black Locust (Robinia pseudo-acacia L.). Many of these sites generate AMD. Conversion of such lands to productive forest while improving the quality of AMD-impaired waters is environmentally and economically desirable to the general public. Unfortunately, financial incentives for individual landowners to invest in 
upgrading their lands are insufficient based on traditional timber markets alone, and there are no financial incentives to encourage landowners to invest in water quality or habitat improvements. It is estimated that restoration of the land through direct public financing would cost the government billions of dollars. Alternatively, market-based incentives for AML reclamation have the potential to result in greater net ecosystem improvements more quickly and at less private (e.g., landowner) and public cost. Potential sources of market incentives for landownerfunded restoration include the development of carbon credits, water quality credits, wetland mitigation credits, and species conservation credits.

This project was designed to demonstrate a market-based reclamation approach through working with multiple partners. The project was funded by the National Energy Technology Laboratory of the U.S. Department of Energy (DOE) through a grant to the Electric Power Research Institute (EPRI). EPRI is responsible for program management, coordination and reporting. The National Mine Land Reclamation Center (NMLRC) of West Virginia University is a co-funder in the project. As a subcontractor to EPRI, NMLRC is responsible for technical oversight as well as construction planning and implementation. GreenVest, another subcontractor to EPRI is responsible for developing the landowner access agreement and valuing any resulting water quality and carbon trading credits. Another partner in this project is Allegheny Energy, who has agreed to provide the fly ash for the soil amendment in return for any resulting carbon sequestration and water quality trading credits. Additional partners, serving in an advisory capacity to the project, are Mr. David Bassage of the West Virginia Department of Environmental Protection's (WVDEP) Office of Innovation; Mr. Keith Pitzer, Executive Director of the Friends of the Cheat, a local watershed organization; and Mr. Bob Runowski of the U.S. Environmental Protection Agency (EPA) Region 3, Watershed Protection Division.

This project was to have provided insight into whether development of carbon sequestration and water quality trading credits on mined lands will provide an economic incentive for landowners and third parties to reclaim more lands to better quality at a faster rate. The project emphasis was on developing water quality and carbon trading credits and creating wildlife habitat by planting trees and warm season grasses. Water quality improvements were to be developed through a water quality enhancement mitigation project using a passive AMD treatment system technology, and potential carbon credits were to be developed through carbon sequestration in planted hardwood trees.

This was to be a three phased project, as discussed below:

- Phase I objectives were to identify an appropriate project site and determine baseline soil carbon, surface hydrology and water quality data and secure regulatory approvals. This work was completed and is discussed in Chapter 2.

- Phase II was to include two major tasks: (1) reforestation and enhancement of $\mathrm{CO}_{2}$ sequestration, and (2) reclamation of AMD affected surface waters. The reforestation was to be accomplished by applying fly ash to the soil as an amendment to provide neutralizing alkalinity, and then planting the site with five species of commercial hardwood tree seedlings. This task was only partially completed. To reclaim the surface waters affected by AMD, a passive AMD treatment system was to be installed in order to achieve reductions in 
acidity, metals and improvement in $\mathrm{pH}$. This task was completed. Both of these tasks are discussed in detail in Chapter 3.

- Because of the issues encountered in the reforestation portion of Phase II, the third phase of work was altered significantly. Phase III had two scopes of work, the first to be performed by an EPRI contractor, the University of West Virginia, and the second to be performed by EPRI when it became apparent that the contractor would not be able to fulfill their obligations in a cost-effective manner. Due to several issues, however, Phase III work did not take place. These issues are discussed in Chapter 4.

- Several conclusions about this type of project can be drawn from the experience of the project team, and are discussed in Chapter 5. 


\section{2 \\ PHASE I}

Phase I of the project was a fairly small effort, with the primary goal being the development of an access agreement from a private landowner whose property met the criteria needed for the project. Other preliminary work completed in Phase I included a land survey, obtaining necessary permits, soil and water sampling, determining the amount of fly ash needed for soil amendment, selecting trees and grasses to be planted on the site, designing a passive treatment system and preparing a site construction bid package. Each of these tasks is outlined in more detail below.

\section{Project Site Location}

The 12-hectare site selected for this project was located on an abandoned Freeport Seam surface mine in Eastern Preston County, near Valley Point, WV that was mined in the early 1970s. It is part of an approximate 48-hectare parcel owned by Mr. and Mrs. Jeff Clark. It is located approximately 17.7 kilometers from Allegheny Energy’s Albright Power Station and contains two AMD seeps - one that drains to Sovern Run and the other that drains to Connor Run (Figure 2-1). Connor Run is a 5.5-kilometer direct tributary of the Cheat River. The site was chosen because it met site selection criteria developed by the project team, as outlined below:

- A mine surface area of approximately 10-15 hectares.

- Located within 25 kilometers of the Allegheny Energy Supply’s Albright Power Station to facilitate fly ash transport.

- An on-site acidic discharge that currently is degrading water quality of receiving streams and impeding development of an aquatic habitat.

- A gently sloping site, with no high wall.

In the late 1990s, the West Virginia Department of Environmental Protection's Abandoned Mine Lands Program partially reclaimed this site. The reclamation consisted of regrading a highwall, installing piping to convey the mine drainage out of collapsed portals, and constructing an open limestone channel to collect the mine water and convey it off of the property to an unnamed tributary of Sovern Run. 


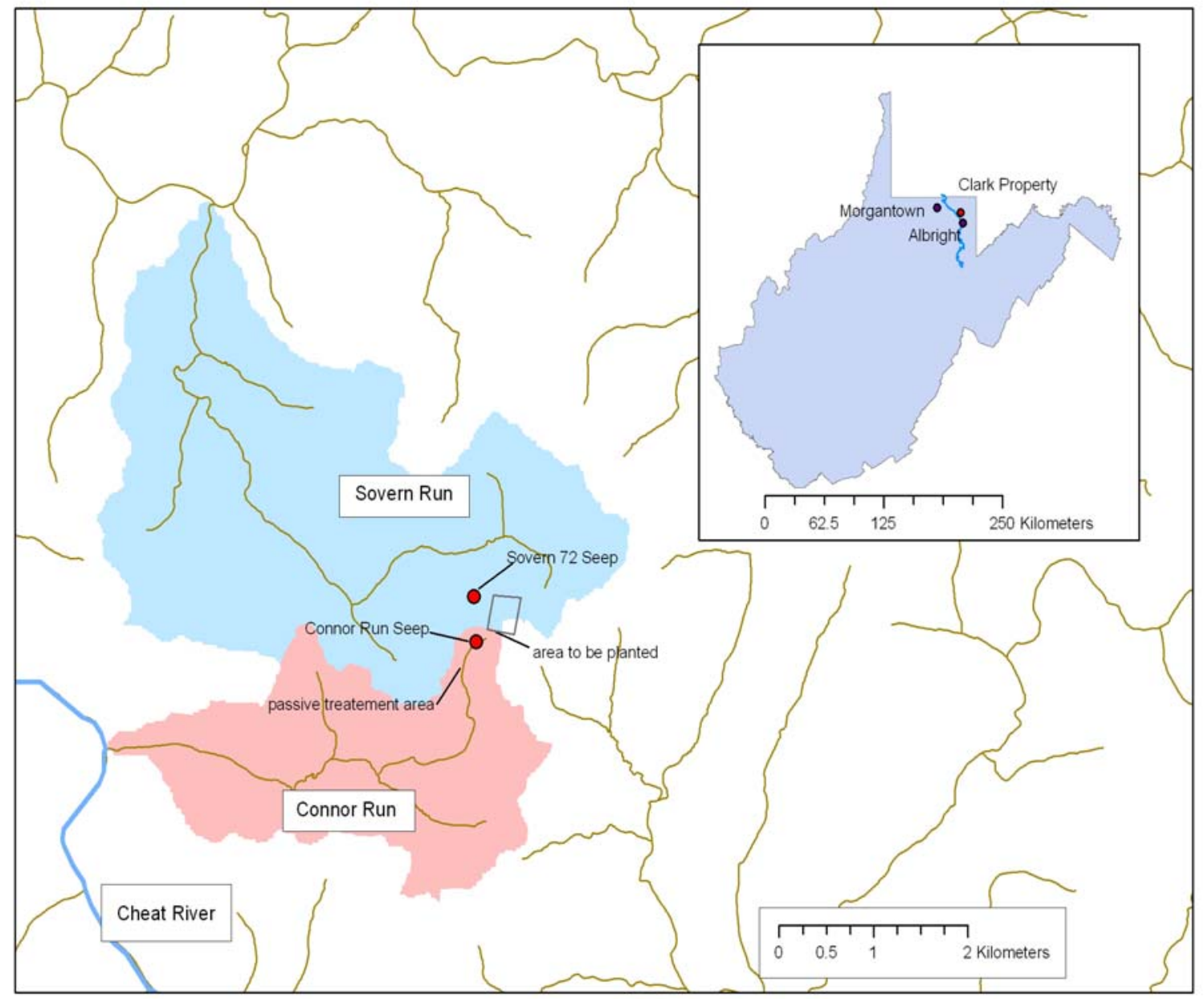

Figure 2-1

Project Location Map Depicting Sovern Run and Connor Run AMD Discharges, Proposed Passive Treatment System and Reforestation Sites

The topography of the reforestation site consisted of gently rolling terrain with relatively young and small woody vegetation. There are assorted small conifers as well as some Black Locust on some portions of the property (Figure 2-2). Also, there is a dense stand of pine trees located in the southwestern portion of the property. This stand of trees also covers two of three sides of a valley that faces southwest. An AMD seep emanates from the toe of the valley and drains to the unnamed tributary of Connor Run (Figure 2-3). 


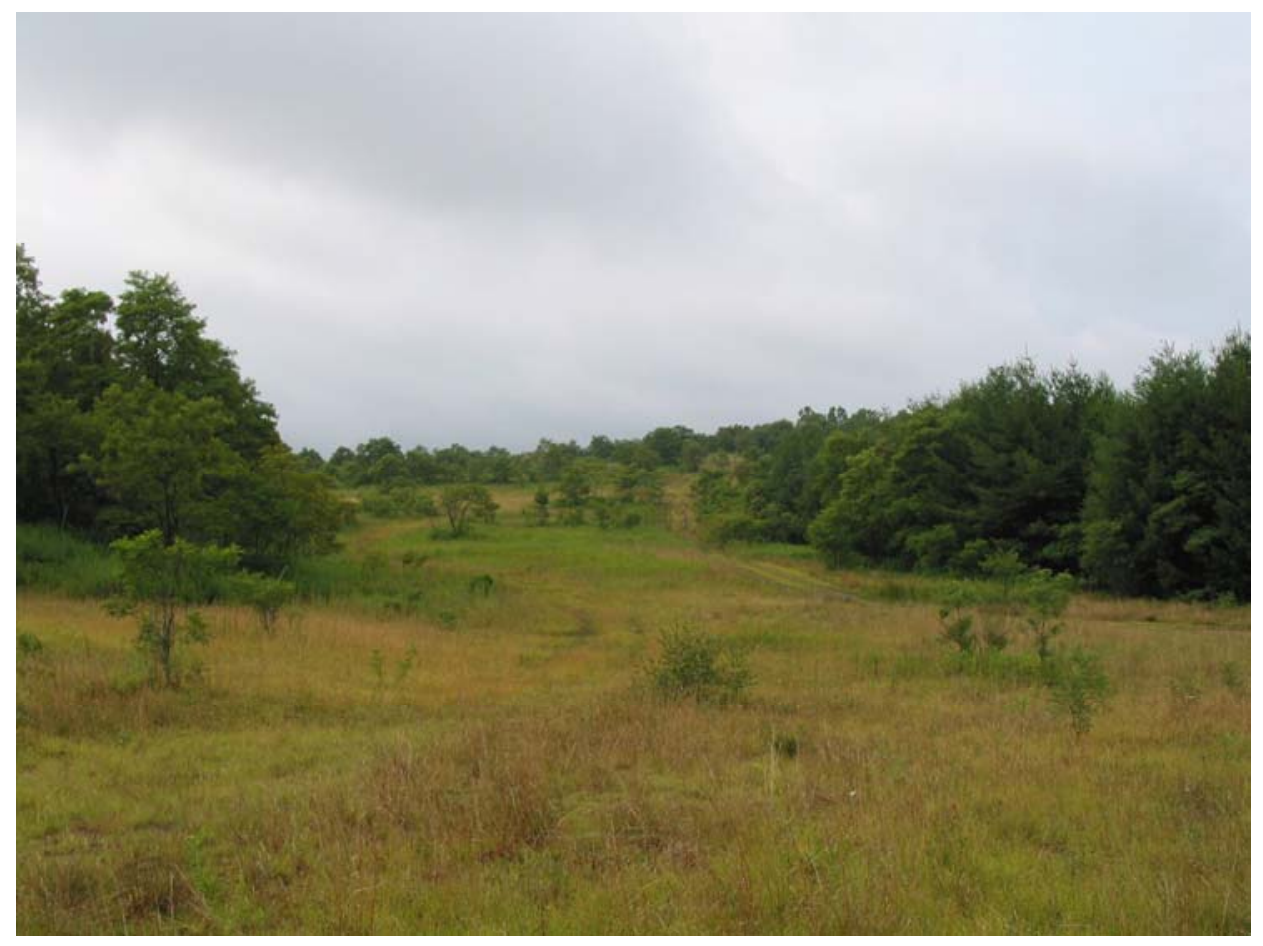

Figure 2-2

Photo of Reforestation Site Prior to Clearing and Grubbing

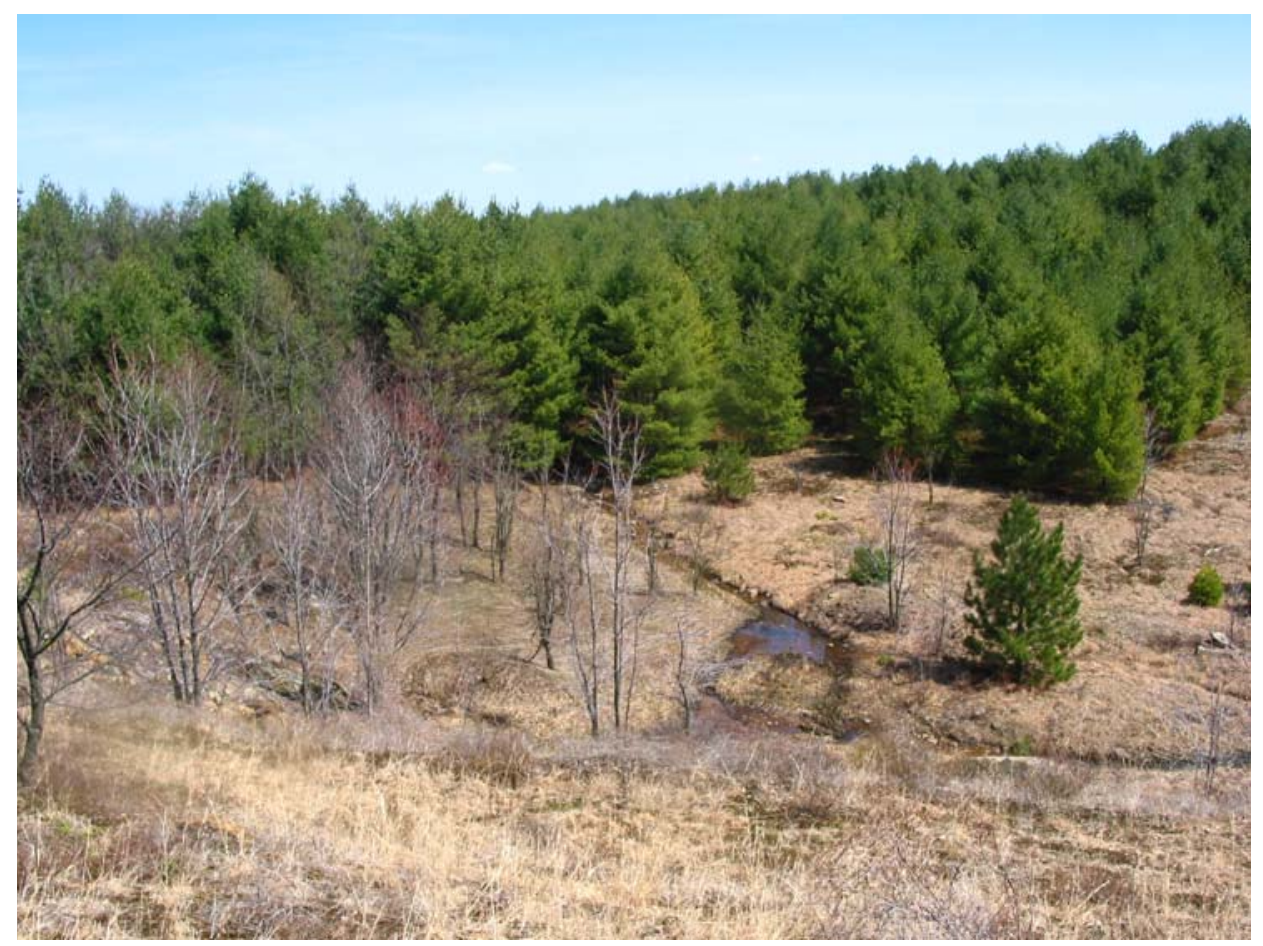

Figure 2-3

Photo of AMD Connor Run Seep Emanating from the Base of Surface Mine Spoil 


\section{Phase I Tasks}

\section{Access Agreement}

Mr. Richard Herd, of the project team, had discussions with Mr. Jeff Clark, the owner of the property. These discussions occurred prior to receiving the Phase I funding. After receipt of the Phase I funding, several site visits took place at the Clark property, including one with the full project team. During these visits, Mr. Clark continued to express interest in the project. Based on this interest, a format for a draft easement used in connection with standard conservation easements was sent to Mr. Clark in July, 2003, as the project team was unsure which portion of the Clark property would be used. In October, 2003 a revised draft, which provided all the details, including a conservation easement, was sent to Mr. Clark.

The project team had verbally agreed with Mr. Clark to construct the passive treatment system on an AMD seep (seep \#72) at the entrance to the project site that discharges to an unnamed tributary of Sovern Run. NMLRC has water quality and flow data for this seep dating to the early 1990s, and a number of baseline water quality samples were collected during Phase I. However, the landowner subsequently notified the project team in November, 2003 of his desire to move the location of the passive treatment system to the back side of his property to address an AMD seep and an AMD contaminated pond that are on a tributary to Connor Run. Additionally, he desired to have the reforestation site moved several hundred meters to the Southeast. The agreement was modified accordingly, but he objected to the duration of the conservation easement proposed for the reforestation site.

In February, 2004, a second revised agreement covering the corrected acreage and incorporating Mr. Clark’s comments was sent to him. After several months of meetings and calls with Mr. Clark, he refused to sign the agreement, expressing concerns over the conservation easement, which would grant the perpetual right of ingress and egress for the property to monitor the development of the carbon credits in the planted trees (see Appendix A).

Faced with the loss of the property, a discussion was held with DOE staff in March 2004, to determine the necessity of fully documenting the development of the carbon credits. Staff indicated that DOE was more interested in documenting the process of the reclamation project than documenting the long-term development of the carbon credits. A new access agreement was drafted by GreenVest, which only required five years of access for R\&D purposes (see Appendix B). This agreement was acceptable to Mr. Clark and he signed it on April 2, 2004.

\section{Land Survey}

A professional survey company surveyed the project site, which encompassed approximately 35 acres. This survey was required for the preparation of the access agreement and the State permit. 


\section{State Permit}

A Construction Storm Water WV/NPDES General Permit was applied for with the West Virginia, Department of Environmental Protection, Division of Water Resources in October, 2003. Along with this permit, a storm water pollution prevention plan was prepared. The permit was granted on December 8, 2003 (Permit No. WV0115924). This permit allowed the site to be disturbed for the application of fly ash and the planting of trees.

\section{Soil and Water Quality Sampling}

Soil and water quality sampling were undertaken to support the Phase II effort. Soil samples were collected and analyzed for paste $\mathrm{pH}$ and neutralization potential (see Tables 2-1 and 2-2). These analyses showed that the soil is acidic with no neutralization potential, as a result of the mining activities. A baseline carbon balance was determined by measuring carbon contents of roots, shoots, detritus and soil (see Table 2-3). These results will be used to calculate the amount of new carbon sequestered on the site as a result of the planting of trees and warm season grasses. 
Table 2-1

Soil Neutralization Potential and Paste pH

\begin{tabular}{|l|l|l|l|}
\hline \multicolumn{5}{|c|}{ Transect 1 } \\
\hline Sample \# & Fiz & N.P. & Paste $\mathrm{pH}$ \\
\hline A-1 & 0 & -0.90 & 4.1 \\
\hline A-2 & 0 & -0.75 & 4.0 \\
\hline A-3 & 0 & -2.98 & 3.7 \\
\hline A-4 & 0 & -1.70 & 4.2 \\
\hline A-5 & 0 & -2.60 & 4.1 \\
\hline A-6 & 0 & -1.93 & 4.2 \\
\hline A-7 & 0 & -2.08 & 4.1 \\
\hline A-8 & 0 & -3.62 & 4.0 \\
\hline A-9 & 0 & -2.47 & 4.0 \\
\hline A-10 & 0 & -2.57 & 4.0 \\
\hline A-11 & 0 & -2.28 & 4.0 \\
\hline A-12 & 0 & -2.39 & 4.1 \\
\hline A-13 & 0 & -0.64 & 4.6 \\
\hline A-14 & 0 & -1.98 & 4.4 \\
\hline A-15 & 0 & -1.41 & 4.0 \\
\hline A-16 & 0 & -2.42 & 4.2 \\
\hline A-17 & 0 & -1.52 & 4.4 \\
\hline A-18 & 0 & -2.31 & 4.4 \\
\hline A-19 & 0 & -3.55 & 4.0 \\
\hline A-20 & 0 & -2.93 & 3.9 \\
\hline A-21 & 0 & -2.80 & 3.9 \\
\hline A-22 & 0 & -3.06 & 3.9 \\
\hline A-23 & 0 & -2.31 & 4.4 \\
\hline A-24 & 0 & -1.49 & 4.3 \\
\hline A-25 & 0 & -1.49 & 4.3 \\
\hline A-26 & 0 & -0.23 & 4.3 \\
\hline A-27 & 0 & -0.82 & 4.6 \\
\hline A-28 & 0 & -0.77 & 4.4 \\
\hline A-29 & 0 & -0.21 & 4.4 \\
\hline A-30 & 0 & -0.92 & 4.3 \\
\hline A-31 & 0 & -1.28 & 4.7 \\
\hline A-32 & 0 & -1.09 & 4.6 \\
\hline A-33 & 0 & -0.98 & 4.4 \\
\hline A-34 & 0 & -0.77 & 4.5 \\
\hline A-35 & 0 & -0.59 & 4.5 \\
\hline A-36 & 0 & 0.92 & 5.5 \\
\hline A-37 & 0 & 17.22 & 6.5 \\
\hline A-38 & 0 & 1.49 & 5.6 \\
\hline A-39 & 0 & 0.15 & 4.4 \\
\hline & Average & -1.08 & 4.36 \\
\hline & & & \\
\hline
\end{tabular}

\begin{tabular}{|l|l|l|l|}
\hline \multicolumn{5}{|c|}{ Transect 2 } \\
\hline Sample \# & Fiz & N.P. & Paste pH \\
\hline B-1 & 0 & -2.05 & 4.0 \\
\hline B-2 & 0 & -2.20 & 3.9 \\
\hline B-3 & 0 & -2.03 & 4.1 \\
\hline B-4 & 0 & -0.82 & 4.3 \\
\hline B-5 & 0 & -1.69 & 4.1 \\
\hline B-6 & 0 & -2.13 & 4.2 \\
\hline B-7 & 0 & -2.82 & 4.1 \\
\hline B-8 & 0 & -1.54 & 4.3 \\
\hline B-9 & 0 & -2.38 & 4.1 \\
\hline B-10 & 0 & -1.90 & 4.0 \\
\hline B-11 & 0 & -1.36 & 4.0 \\
\hline B-12 & 0 & -1.26 & 4.1 \\
\hline B-13 & 0 & -2.08 & 4.5 \\
\hline B-14 & 0 & -2.64 & 4.3 \\
\hline B-15 & 0 & -2.13 & 4.3 \\
\hline B-16 & 0 & -2.15 & 4.4 \\
\hline B-17 & 0 & -1.64 & 4.5 \\
\hline B-18 & 0 & -2.31 & 4.4 \\
\hline B-19 & 0 & -1.38 & 4.5 \\
\hline B-20 & 0 & -2.49 & 4.3 \\
\hline B-21 & 0 & -1.44 & 4.5 \\
\hline & & & \\
\hline & Average & -1.93 & 4.23 \\
\hline & & & \\
\hline
\end{tabular}


Table 2-2

Carbon Content of Living Vegetation

\begin{tabular}{|l|c|c|c|l|}
\hline \multicolumn{5}{|c|}{ Transect 1 } \\
\hline & $105^{\circ}$ C & $400^{\circ} \mathrm{C}$ & & \\
\hline & Oven Dry & Oven Dry & & \\
\hline Sample \# & Sample Wt. & Sample Wt. & Difference & $\%$ Carbon \\
\hline A-1 & 1.6864 & 0.1705 & 1.5159 & 89.89 \\
\hline A-2 & 1.6579 & 0.1133 & 1.5446 & 93.17 \\
\hline A-3 & 1.6602 & 0.0583 & 1.6019 & 96.49 \\
\hline A-4 & 1.6676 & 0.0559 & 1.6117 & 96.65 \\
\hline A-5 & 1.6473 & 0.0641 & 1.5832 & 96.11 \\
\hline A-6 & 1.6611 & 0.0656 & 1.5955 & 96.05 \\
\hline A-7 & 1.6975 & 0.3022 & 1.3953 & 82.20 \\
\hline A-8 & 1.7092 & 0.0672 & 1.6420 & 96.07 \\
\hline A-9 & 1.8226 & 0.0605 & 1.7621 & 96.68 \\
\hline A-10 & 1.8124 & 0.0562 & 1.7562 & 96.90 \\
\hline A-11 & 1.8084 & 0.0704 & 1.7380 & 96.11 \\
\hline A-12 & 1.8209 & 0.0777 & 1.7432 & 95.73 \\
\hline A-13 & 1.1639 & 0.1158 & 1.0481 & 90.05 \\
\hline A-14 & 1.8088 & 0.0826 & 1.7262 & 95.43 \\
\hline A-15 & 1.7055 & 0.0596 & 1.6459 & 96.51 \\
\hline A-16 & 1.8209 & 0.0876 & 1.7333 & 95.19 \\
\hline A-17 & 1.8230 & 0.0699 & 1.7531 & 96.17 \\
\hline A-18 & 1.8190 & 0.0974 & 1.7216 & 94.65 \\
\hline A-19 & 1.8518 & 0.2651 & 1.5867 & 85.68 \\
\hline A-20 & 1.8079 & 0.0813 & 1.7266 & 95.50 \\
\hline A-21 & 1.6835 & 0.0707 & 1.6128 & 95.80 \\
\hline A-22 & 1.8238 & 0.2773 & 1.5465 & 84.80 \\
\hline A-23 & 1.8568 & 0.1332 & 1.7236 & 92.83 \\
\hline A-24 & 1.6998 & 0.1097 & 1.5901 & 93.55 \\
\hline A-25 & 1.8193 & 0.0564 & 1.7629 & 96.90 \\
\hline A-26 & 1.8598 & 0.0534 & 1.8064 & 97.13 \\
\hline A-27 & 1.8690 & 0.0571 & 1.8119 & 96.94 \\
\hline A-28 & 1.8853 & 0.0851 & 1.8002 & 95.49 \\
\hline A-29 & 1.7151 & 0.0600 & 1.6551 & 96.50 \\
\hline A-30 & 1.2858 & 0.4350 & 0.8508 & 66.17 \\
\hline A-31 & 0.9393 & 0.0539 & 0.8854 & 94.26 \\
\hline A-32 & 1.8457 & 0.1020 & 1.7437 & 94.47 \\
\hline A-33 & 1.7219 & 0.0812 & 1.6407 & 95.28 \\
\hline A-34 & 0.9797 & 0.5972 & 0.3825 & 39.04 \\
\hline A-35 & 0.7624 & 0.1127 & 0.6497 & 85.22 \\
\hline A-36 & 1.0703 & 0.1133 & 0.9570 & 89.41 \\
\hline A-37 & 0.9811 & 0.0581 & 0.9230 & 94.08 \\
\hline A-38 & 0.9330 & 0.0552 & 0.8778 & 94.08 \\
\hline A-39 & 1.8700 & 0.0915 & 1.7785 & 95.11 \\
\hline & 63.05 & $4 v e r a g e$ & 1.4982 & 91.75 \\
\hline & & & 58.43 & 92.67 \\
\hline All weights are measured in grams & & \\
\hline & & & \\
\hline
\end{tabular}


Table 2-2 (cont.)

Carbon Content of Living Vegetation

\begin{tabular}{|l|c|c|c|l|}
\hline & Transect 2 & & & \\
\hline & & & & \\
\hline & $105^{\circ} \mathrm{C}$ & $400^{\circ} \mathrm{C}$ & & \\
\hline & Oven Dry & Oven Dry & & \\
\hline Sample \# & Sample Wt. & Sample Wt. & Difference & $\%$ Carbon \\
\hline B-1 & 1.8285 & 0.1621 & 1.6664 & 91.13 \\
\hline B-2 & 1.6913 & 0.0572 & 1.6341 & 96.62 \\
\hline B-3 & 1.8190 & 0.0893 & 1.7297 & 95.09 \\
\hline B-4 & 1.4986 & 0.0730 & 1.4256 & 95.13 \\
\hline B-5 & 1.8212 & 0.0674 & 1.7538 & 96.30 \\
\hline B-6 & 1.8380 & 0.1038 & 1.7342 & 94.35 \\
\hline B-7 & 1.8075 & 0.0680 & 1.7395 & 96.24 \\
\hline B-8 & 1.7032 & 0.5590 & 1.1442 & 67.18 \\
\hline B-9 & 1.7104 & 0.0577 & 1.6527 & 96.63 \\
\hline B-10 & 1.8265 & 0.1402 & 1.6863 & 92.32 \\
\hline B-11 & 1.8123 & 0.0648 & 1.7475 & 96.42 \\
\hline B-12 & 1.7143 & 0.0557 & 1.6586 & 96.75 \\
\hline B-13 & 1.7034 & 0.0606 & 1.6428 & 96.44 \\
\hline B-14 & 1.8331 & 0.0852 & 1.7479 & 95.35 \\
\hline B-15 & 1.7162 & 0.0606 & 1.6556 & 96.47 \\
\hline B-16 & 1.7312 & 0.0487 & 1.6825 & 97.19 \\
\hline B-17 & 1.7142 & 0.0927 & 1.6215 & 94.59 \\
\hline B-18 & & & - & \\
\hline B-19 & 1.1140 & 0.0598 & 1.0542 & 94.63 \\
\hline B-20 & 1.7219 & 0.0594 & 1.6625 & 96.55 \\
\hline B-21 & 1.6221 & 0.0548 & 1.5673 & 96.62 \\
\hline & & & & \\
\hline & & Average & 1.5337 & 94.10 \\
\hline
\end{tabular}

Table 2-3

Carbon Mass Balance

\begin{tabular}{|l|c|}
\hline Carbon Mass Balance for Clark Property & $\mathbf{g} / \mathbf{m} \mathbf{2}$ \\
\hline Living Material (roots, shoots, \& stems) & 213.2 \\
\hline Detritus Material (dead roots, shoots, \& stems) & 193.3 \\
\hline Soil Material & 43.7 \\
\hline
\end{tabular}


Water quality sampling of AMD was conducted during one high- and one low-flow condition to support the design of the passive AMD treatment system. The results of these analyses are shown in Table 2-4 below. These results will not be used for design, as the landowner requested that the passive treatment system be moved to a new location on the site.

Table 2-4

Water Quality Sampling Data of Acid Mine Drainage

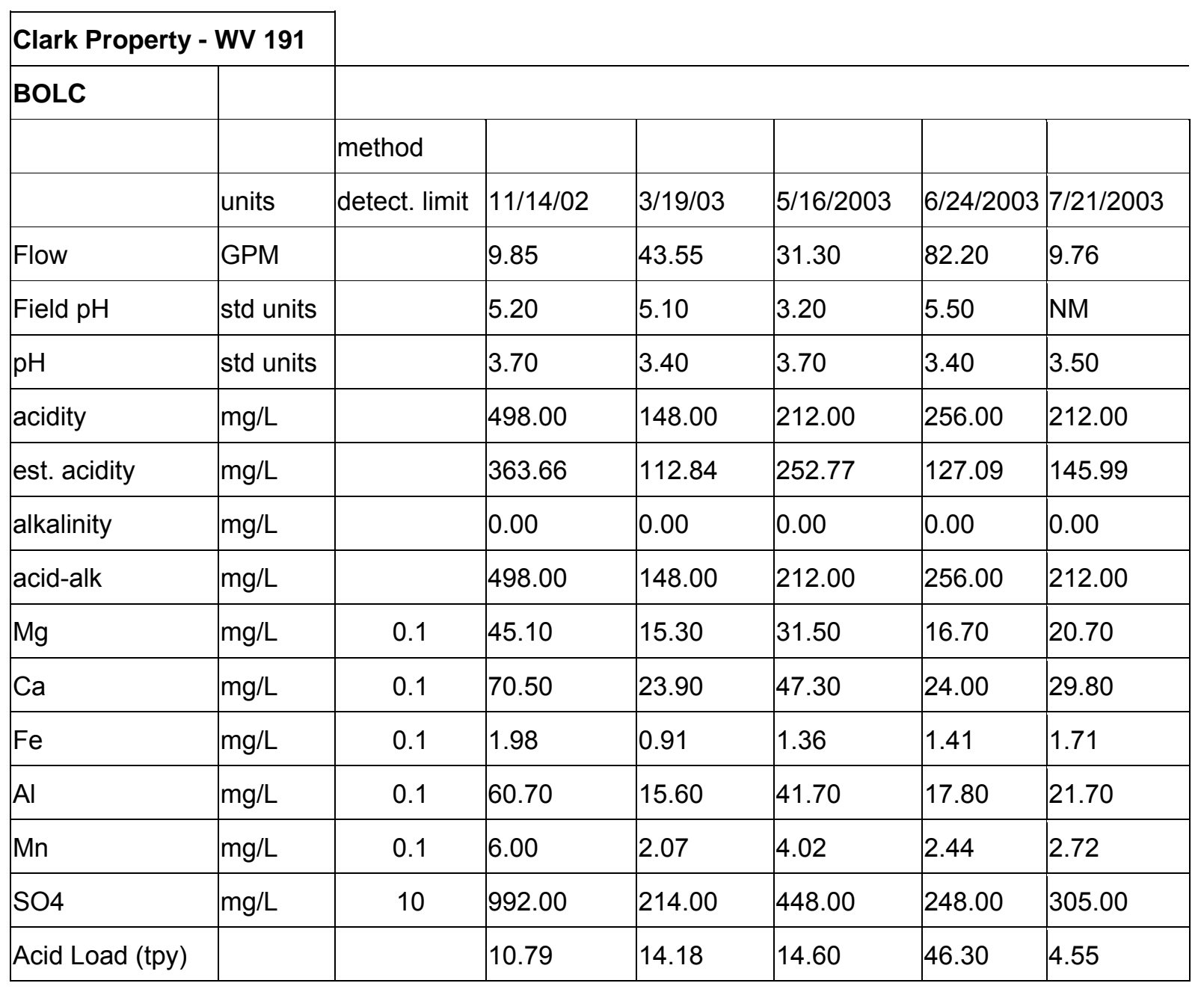


Table 2-4 (cont.)

Connor Run - WV

191

\begin{tabular}{|l|l|l|l|l|l|}
\hline & & method & & & \\
\hline & units & detect. limit & $10 / 2 / 03$ & & \\
\hline Flow & GPM & & 23.30 & & \\
\hline Field $\mathrm{pH}$ & $\begin{array}{l}\text { std } \\
\text { units }\end{array}$ & & 3.90 & & \\
\hline pH & $\begin{array}{l}\text { std } \\
\text { units }\end{array}$ & & 3.70 & & \\
\hline acidity & $\mathrm{mg} / \mathrm{L}$ & & 147.00 & & \\
\hline est. acidity & $\mathrm{mg} / \mathrm{L}$ & & 159.62 & & \\
\hline alkalinity & $\mathrm{mg} / \mathrm{L}$ & & 0.00 & & \\
\hline acid-alk & $\mathrm{mg} / \mathrm{L}$ & & 147.00 & & \\
\hline Mg & $\mathrm{mg} / \mathrm{L}$ & 0.1 & 28.40 & & \\
\hline Ca & $\mathrm{mg} / \mathrm{L}$ & 0.1 & 32.80 & & \\
\hline Fe & $\mathrm{mg} / \mathrm{L}$ & 0.1 & 35.30 & & \\
\hline Al & $\mathrm{mg} / \mathrm{L}$ & 0.1 & 6.86 & & \\
\hline Mn & $\mathrm{mg} / \mathrm{L}$ & 0.1 & 9.17 & & \\
\hline SO4 & $\mathrm{mg} / \mathrm{L}$ & 10 & 368.00 & & \\
\hline Acid Load (tpy) & & 7.54 & & \\
\hline
\end{tabular}


Table 2-4 (cont.)

\begin{tabular}{|l|l|l|l|}
\hline $\begin{array}{l}\text { *DS Connor } \\
\text { Run }\end{array}$ & & method & \\
\hline & units & detect. limit & $5 / 23 / 03$ \\
\hline Flow & GPM & & 295.00 \\
\hline Field pH & $\begin{array}{l}\text { std } \\
\text { units }\end{array}$ & & 3.30 \\
\hline pH & $\begin{array}{l}\text { std } \\
\text { units }\end{array}$ & & 3.40 \\
\hline acidity & $\mathrm{mg} / \mathrm{L}$ & & 121.00 \\
\hline est. acidity & $\mathrm{mg} / \mathrm{L}$ & & 103.38 \\
\hline alkalinity & $\mathrm{mg} / \mathrm{L}$ & & 0.00 \\
\hline acid-alk & $\mathrm{mg} / \mathrm{L}$ & & 121.00 \\
\hline Mg & $\mathrm{mg} / \mathrm{L}$ & 0.1 & 16.50 \\
\hline Ca & $\mathrm{mg} / \mathrm{L}$ & 0.1 & \\
\hline Fe & $\mathrm{mg} / \mathrm{L}$ & 0.1 & 3.75 \\
\hline Al & $\mathrm{mg} / \mathrm{L}$ & 0.1 & 11.60 \\
\hline Mn & $\mathrm{mg} / \mathrm{L}$ & 0.1 & 4.90 \\
\hline SO4 & $\mathrm{mg} / \mathrm{L}$ & 10 & 197.00 \\
\hline Acid Load (tpy) & & 78.53 \\
\hline
\end{tabular}

* Sample Collected approximately 1 mile ds of seep at bridge off of CR 14-5 
Table 2-4 (cont.)

\begin{tabular}{|c|c|c|}
\hline \multicolumn{3}{|c|}{ March 2004 Sampling } \\
\hline Pond & & Pond \\
\hline date & & $3 / 23 / 2004$ \\
\hline Flow & gpm & $\mathrm{NM}$ \\
\hline Field pH & $\begin{array}{c}\text { std } \\
\text { units }\end{array}$ & $\mathrm{NM}$ \\
\hline pH & $\begin{array}{c}\text { std } \\
\text { units }\end{array}$ & 4.1 \\
\hline acidity & $\mathrm{mg} / \mathrm{l}$ & 114 \\
\hline est. acidity & $\mathrm{mg} / \mathrm{l}$ & 104.02 \\
\hline alkalinity & $\mathrm{mg} / \mathrm{l}$ & 0 \\
\hline acid-alk & $\mathrm{mg} / \mathrm{l}$ & 114 \\
\hline acid load & tons/yr & $\mathrm{NM}$ \\
\hline Mg & $\mathrm{mg} / \mathrm{L}$ & 17.3 \\
\hline Ca & $\mathrm{mg} / \mathrm{L}$ & 19.2 \\
\hline Fe & $\mathrm{mg} / \mathrm{L}$ & 0.23 \\
\hline Al & $\mathrm{mg} / \mathrm{L}$ & 17.2 \\
\hline Mn & $\mathrm{mg} / \mathrm{L}$ & 3.81 \\
\hline sO4 & $\mathrm{mg} / \mathrm{L}$ & 224 \\
\hline Cond & & 425 \\
\hline
\end{tabular}


Table 2-4 (cont.)

\begin{tabular}{|l|l|l|}
\hline Seep & & \\
\hline & & Seep \\
\hline date & & $3 / 23 / 2004$ \\
\hline Flow & gpm & 2.64 \\
\hline Field $\mathrm{pH}$ & $\begin{array}{l}\text { std } \\
\text { units }\end{array}$ & $\mathrm{NM}$ \\
\hline pH & std & \\
\hline anits & 3.4 \\
\hline est. acidity & $\mathrm{mg} / \mathrm{l}$ & 171 \\
\hline alkalinity & $\mathrm{mg} / \mathrm{l}$ & 0 \\
\hline acid-alk & $\mathrm{mg} / \mathrm{l}$ & 171 \\
\hline acid load & tons/yr & 0.99 \\
\hline Mg & $\mathrm{mg} / \mathrm{L}$ & 30.1 \\
\hline Ca & $\mathrm{mg} / \mathrm{L}$ & 33.8 \\
\hline Fe & $\mathrm{mg} / \mathrm{L}$ & 28.6 \\
\hline Al & $\mathrm{mg} / \mathrm{L}$ & 11.3 \\
\hline Mn & $\mathrm{mg} / \mathrm{L}$ & 9.56 \\
\hline SO4 & $\mathrm{mg} / \mathrm{L}$ & 363 \\
\hline Cond & & 757 \\
\hline & & \\
\hline
\end{tabular}


Table 2-4 (cont.)

\begin{tabular}{|l|l|r|}
\hline \multicolumn{2}{|l|}{ Confluence } & \\
\hline $\begin{array}{l}\text { Sampling } \\
\text { Station }\end{array}$ & & Confluence \\
\hline date & & $3 / 23 / 2004$ \\
\hline Flow & gpm & 3.2 \\
\hline Field $\mathrm{pH}$ & $\begin{array}{l}\text { std } \\
\text { units }\end{array}$ & $\mathrm{NM}$ \\
\hline pH & std \\
units & 3.7 \\
\hline acidity & $\mathrm{mg} / \mathrm{l}$ & 102 \\
\hline est. acidity & $\mathrm{mg} / \mathrm{l}$ & 118.86 \\
\hline alkalinity & $\mathrm{mg} / \mathrm{l}$ & 0 \\
\hline acid-alk & $\mathrm{mg} / \mathrm{l}$ & 102 \\
\hline acid load & tons/yr & 0.72 \\
\hline Mg & $\mathrm{mg} / \mathrm{L}$ & 18.4 \\
\hline Ca & $\mathrm{mg} / \mathrm{L}$ & 24.9 \\
\hline Fe & $\mathrm{mg} / \mathrm{L}$ & 11.5 \\
\hline Al & $\mathrm{mg} / \mathrm{L}$ & 10 \\
\hline Mn & $\mathrm{mg} / \mathrm{L}$ & 5.68 \\
\hline SO4 & $\mathrm{mg} / \mathrm{L}$ & 221 \\
\hline Cond & & 481 \\
\hline
\end{tabular}

\section{Fly Ash Chemistry: Allegheny Energy's Albright Power Plant}

Fly ash from the burning of bituminous coal at the Albright Power Plant will be used as a soil amendment. The fly ash will be trucked to the site and dumped along the eastern edge of the site. After dumping, it will be graded over the site and then tilled into the soil. Appendix $\mathrm{C}$ provides the calculation for determining the amount of fly ash required for soil amendment. Based on this analysis, it was determined that approximately 7,640 tons of fly ash will be required to amend the site. 


\section{Tree and Grass Selection}

After discussions with the project team and the landowner, it was decided to plant the following types of trees and grasses on the site:

- Red and White Oak

- Black Cherry

- Tulip (yellow) Poplar

- White Pine

- Warm season grasses

How the trees and grasses will be distributed over the site was to be determined during Phase II of the project.

\section{Passive Treatment System}

The location of the passive treatment system has been moved to the Connor Run drainage as a result of the landowner's wishes. Connor Run is a tributary to the Cheat River.

A conceptual design of the passive treatment system was prepared based on results of new water quality sampling and the topography of the site, which will be described in Chapter 3 . In essence, the design incorporates a lime interceptor trench, open limestone channels and two shallow retention ponds to neutralize the acidic waters.

\section{Site Construction Bid Package}

A bid package was prepared by West Virginia University for Phase II reforestation site preparation. The package contained the following activities:

- Mobilization

- Clearing and grubbing the site

- Access road construction, including materials

- Placement of two culverts

- Spreading of fly ash

- Tilling/ripping fly ash into soil

Additionally, local nurseries were contacted to determine the availability and cost of trees. 


\section{Conclusion}

All of the work for Phase I was completed with the exception of Mr. Clark signing the conservation easement. As described earlier, after several months of negotiations, it was determined that Mr. Clark was not willing to sign the conservation easement. DOE indicated that they were more interested in documenting the process of the reclamation project than documenting the long-term development of the carbon credits. A new access agreement was drafted which only required five years of access for R\&D purposes. This agreement was acceptable to Mr. Clark and he signed it on April 2, 2004 (see Appendix B). Signing of the agreement marked the beginning of Phase II of the project. 


\section{PHASE II}

\section{Introduction}

Phase II began in April, 2004 once Mr. Clark had signed the R\&D access agreement, and was expected to be completed by the end of 2005. Shown below is the list of deliverables followed by a detailed explanation of the work that was performed in each of these tasks.

\section{Phase II Workscope}

\section{Deliverables}

1. Passive AMD treatment system. The AMD treatment system will be constructed and fully operational capable of neutralizing acidity and removing a substantial portion of the $\mathrm{Fe}, \mathrm{Al}$ and Mn loading emanating from the project site.

2. Reforest and enhance carbon sequestration project site. The thirty acre project site will be reforested with five bare root tree species planted in a random design. Twenty five acres will be amended with fly ash and five acres of the site will serve as a control.

3. Quantify water quality and carbon sequestration credits. Water quality improvements resulting from the passive AMD treatment system will be compared to pre-treatment baseline data to determine pollutant load reductions to Connor Run. Soil and vegetative carbon measurements will be made in the control and ash treatment plots and compared to baseline to quantify the increase in carbon sequestration. Any differential carbon sequestration rate between control and ash treatment plots will be described.

4. Final Report. The final report will describe the project objective, approach, material and methods and resulting environmental and economic benefits of using a market-based approach for AML restoration.

\section{Detailed Description of Phase II Tasks}

\section{Task 1: Passive AMD Treatment System for Reclamation of AMD Affected Surface Waters}

Task 1 was to develop water quality credits by constructing a passive AMD treatment system for the acidic discharge and monitoring its treatment performance compared to baseline water quality. The plan was to use the results from the preliminary field investigation and water quality assessment to design a passive AMD treatment system based on the unique attributes of the selected AMD site, and treatment methods selected based on water chemistry, flow, treatment needs and physical setting. 
Pre- and post-treatment water quality was to be determined using the following methods:

- Field pH will be determined at each stream sampling station using a Corning 312 Portable $\mathrm{pH}$ meter.

- Stream channel width and depth will be measured at each sampling station using surveyor tape and other appropriate distance measuring devices.

- Flow will be determined at each sampling station, using either a Marsh McBirney flow meter or another reliable flow measuring technique.

Water samples from each sampling station are filtered through a $0.45 \mathrm{um}$ filter and collected into two new, plastic, $250 \mathrm{ml}$ sampling bottles. The non-acidified sample will be analyzed for $\mathrm{pH}$, acidity, alkalinity, sulfate and conductivity. The acidified sample will be used for elemental analysis (Fe, Mn, Al, Ca and Mg) using ICP technology.

Table 3-1 shows the EPA and Standard Methods that were used for the analysis of the water quality samples. 
Table 3-1

EPA $^{1}$ and Standard Methods ${ }^{2}$ Used for Analyzing Water Quality Samples

\begin{tabular}{|l|l|l|}
\hline Parameter & Method & $\begin{array}{l}\text { Detection } \\
\text { Limit (mg/L) }\end{array}$ \\
\hline Flow & Marsh-McBirney Flow Meter & \\
\hline $\mathrm{pH}$ & EPA 150.1, Electrometric & 0.1 \\
\hline Field pH & Oakton pH pen & $+/-0.2$ \\
\hline Acidity & EPA 305.1, Titrametric & 1.0 \\
\hline Acid Load (Tons/yr) & Flow (gals/min.) $\times$ Acidity Conc. $x .0022$ & \\
\hline Mineral Acidity & SM 2310, Titrametric & 1.0 \\
\hline Estimated Acidity & Based on [H, Fe, Al, Mn] & \\
\hline Alkalinity & EPA 310.1, Titrametric & 1.0 \\
\hline Iron & EPA 200.7, ICP & 0.05 \\
\hline Manganese & EPA 160.2, Gravimetric & 0.01 \\
\hline Conductivity & EPA 120.1, Specific Conductivity & 1.0 umho \\
\hline Sulfate & EPA 300.0 & 1.0 \\
\hline Aluminum & EPA 200.7, ICP & 0.05 \\
\hline Calcium & EPA 200.7, ICP & 0.01 \\
\hline Magnesium & EPA 200.7, ICP & 0.01 \\
\hline
\end{tabular}

\section{AMD Treatment Site Evaluation and Identification of Treatment Alternatives}

Following is a description of the process NMLRC uses to evaluate a site's AMD treatment needs, treatment alternatives and the basis for designing the treatment system. The process includes: conducting a field reconnaissance and collecting samples; evaluating treatment alternatives in consideration of AMD quality, flow, and site constraints, and budget; and developing the final system design.

It is critical to determine project objectives and to articulate a project outcome within the constraints of budget, time and technology. It is also important to recognize that AMD treatment under field conditions is not an exact science. Flows vary seasonally and over multiple yearly cycles. Pollutant concentrations also vary. Where possible, it is useful to phase in treatments until water quality targets are achieved. Otherwise, the tendency is to over build the systems. The following checklist is used to focus effort on maximum information gain while simplifying the process of selecting treatment options. 


\section{Phase I: Watershed Evaluation}

This represents the initial watershed sampling. Often, the local sponsors invest considerable effort toward water sampling prior to identifying and prioritizing at-source control needs. Collation of this information, along with data QA/QC is an important initial step. Phase I identifies the total pollutant loads in the watershed and the proportion contributed by each source. This highlights the 'hot spots' in the watershed and helps to focus more intensive follow-on sampling in Phase II.

- Mapping

- Stream quality

o pH, acidity, alkalinity, $\mathrm{Fe}^{2+}, \mathrm{Fe}^{3+}, \mathrm{Al}, \mathrm{Mn}$, sulfate, conductivity

o As needed: Sb, As, Ba, Be, Cd, Cr ${ }^{6+}, \mathrm{Pb}, \mathrm{Hg}, \mathrm{Ni}, \mathrm{Se}, \mathrm{Ag}, \mathrm{Tl}$

- Hydrologic survey

o Flow, annual cycle, mass balance

- Identify high load stream segments:

o Display high load stream segments on watershed map

Phase II: Site Evaluation

While phase I sampling indicates the priority pollutant sources in the watershed, phase II sampling characterizes them to allow for treatment system design.

- Treatment site water quality

o $\mathrm{pH}$, acidity, alkalinity, $\mathrm{Fe}^{2+}, \mathrm{Fe}^{3+}, \mathrm{Al}, \mathrm{Mn}$, sulfate, conductivity

o As needed: Sb, As, Ba, Be, Cd, Cr ${ }^{6+}, \mathrm{Pb}, \mathrm{Hg}, \mathrm{Ni}, \mathrm{Se}, \mathrm{Ag}, \mathrm{Tl}$

- Hydrologic survey:

o Flow, annual cycle, mass balance impact

- Prioritize treatment sites

- Identify treatment needs

o Alkalinity, oxidation, metal floc handling 


\section{Phase III: Identify Treatment Needs}

Evaluation of phase II data allows development of initial designs and costs. The following questions are to be addressed during Phase III:

- Is alkalinity required?

O Quantity needed (tons/year)

o Alkalinity options

- Limestone

- Steel slag

- Kiln dust

- Is oxidation required?

$$
\text { o } \mathrm{Fe}^{2+} \text { load (tons/year) }
$$

- Is floc removal needed?

- Amount of floc handling needed (tons/solid/year)

Phase IV: Treatment Technology Selection

A decision process, as described in Table 3-2, is used to identify treatment needs and their cost implications.

Table 3-2

Decision Document for Determining Proper AMD Treatment

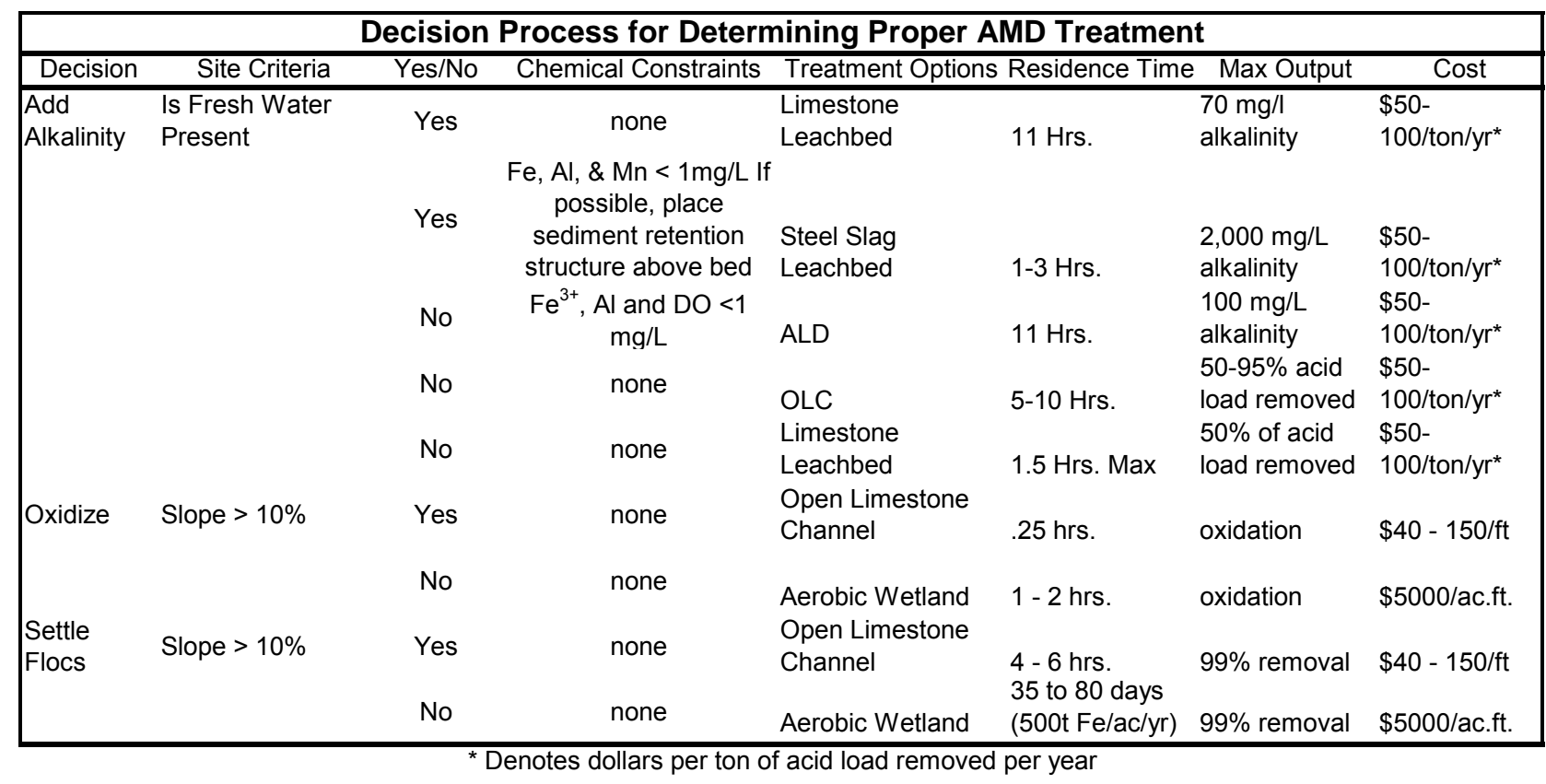


If one year after construction and commissioning, the system meets water treatment expectations then the design and construction process is complete. Otherwise, return to Phase II above.

Critical Parameters in Watershed Planning and Remediation

The following parameters are critical in assessing design needs of an AMD remediation project:

$\mathrm{pH}$

- Hydrogen ion concentration

Acidity (mg/L)

- Concentration of base needed to neutralize a volume of water

- $50 \times\left(\left(\mathrm{V}_{\mathrm{o}} \mathrm{x}\left(\left[\mathrm{Me}_{1}\right] / \mathrm{A}_{1}\right)\right)+\left(\mathrm{V}_{\mathrm{o}} \times\left(\left[\mathrm{Me}_{2}\right] / \mathrm{A}_{2}+\ldots+\left(1000 \times 10^{-\mathrm{pH}}\right)\right.\right.\right.$

- Where: $\mathrm{V}_{\mathrm{o}}=$ valence at treatment oxidation state

$[\mathrm{Me}]_{1 \text { to n }}=$ metal ion concentration $(\mathrm{mg} / \mathrm{L})$

$\mathrm{A}_{1 \text { to } \mathrm{n}}=$ atomic weight of metal ion

- Acidity is given in mg/L (Calcium Carbonate Equivalent)

- $\quad$ Flow: liters per minute $(\mathrm{lpm}) * 0.00059=$ cubic $\mathrm{ft} / \mathrm{second}(\mathrm{cfs})$

$\underline{\text { Acid load }}$

- Mass of base needed to neutralize a given mass of acid

- $\quad$ Based on concentration (mg/L) and flow (gallons per minute $(\mathrm{gpm}) * 0.00059=$ cubic $\mathrm{ft} /$ second (cfs)

o Dynamic

flow $(\mathrm{gpm})$ x acidity $(\mathrm{mg} / \mathrm{L})$ x 0.0022 = tons/year

flow (gpm) x acidity (mg/L) x 86.4 = lbs/day

o Static

volume $\left(\mathrm{ft}^{3}\right)$ x acidity $(\mathrm{mg} / \mathrm{L}) \times 3.11485 \times 10^{-10}=$ tons

volume $(\mathrm{gpm}) \mathrm{x}$ acidity $(\mathrm{mg} / \mathrm{L}) \times 4.16383 \times 10^{-11}=$ tons

- The same formulas can be used to estimate the mass of alkalinity 


\section{Mass of chemical}

To calculate the mass of treatment chemical multiply the acid load by:

\begin{tabular}{|l|l||}
\hline $\mathrm{CaCO}_{3}$ & $100 \%$ \\
\hline $\mathrm{Ca}(\mathrm{OH})_{2}$ & $74 \%$ \\
\hline $\mathrm{CaO}$ & $56 \%$ \\
\hline $\mathrm{NaOH}$ & $40 \%$ \\
\hline $\mathrm{Na}_{2} \mathrm{CO}_{3}$ & $106 \%$ \\
\hline $\mathrm{NH}_{3}$ & $17 \%$ \\
\hline
\end{tabular}

$\underline{\text { Acid/base mass balance }}$

- $\quad$ Tons of acid-tons of alkalinity = net acid load

Residence time (T)

- $\quad \mathrm{T}_{\text {hours }}=$ cross sectional area $\left(\mathrm{ft}^{2}\right) \times$ length (ft) $\mathrm{x} \%$ voids/flow (cfs) $\mathrm{x} 3600$

- Where: Voids $=40$ to $50 \%$ for rip-rap sized limestone

$\underline{\text { Hydraulic considerations }}$

- Many passive treatment systems put AMD in direct contact with limestone.

- Most passive systems fail due to filling of the void spaces with metal flocs.

- $\quad$ Ferric hydroxide flocs will form above pH 3.2 and aluminum flocs above pH 4.2.

- When treating AMD it is critical to minimize opportunities for floc accumulation.

- It is always better to use large dimension limestone (> 6 in.).

- Place a six inch bed of 0" to 1" crusher run limestone or steel slag below sized limestone.

- Only use crusher run limestone as a bedding material.

- Ensure that there is a good hydraulic connection between the source of AMD and the treatment structure.

- If the AMD can find a way around the treatment structure, it generally will.

- With ALDs, avoid discharges with widely varied flows. Low flow periods will create an air space in the ALD, encouraging ferric hydroxide formation. Steady flows work best.

- Open Limestone Channels (OLC) operate over a wide variety of flows and chemical conditions

- Make sure your ponds do not LEAK! 


\section{Cost estimation}

- Excavation: Cross sectional area x length /27 x \$3.00

- Limestone: Should be between $\$ 15$ and $\$ 30$ /ton delivered

- Organics: Vary widely in availability and cost. Straw bales, manure and peat can be used. Where permeability is critical as in a vertical flow wetland, avoid peat.

- Other costs: Access, clearing, reclamation and other items too site specific to permit generalization

Fe sludge formation

- $\mathrm{Fe}^{3}+3 \mathrm{H}_{2} \mathrm{O}=\mathrm{Fe}(\mathrm{OH})_{3}+3 \mathrm{H}+$

o $56 \mathrm{~g} / \mathrm{g}$ mole $=>107 \mathrm{~g} / \mathrm{g}$ mole

- Inflow Fe = $1.0 \mathrm{mg} / \mathrm{L}$ x $43.53 \mathrm{~L} / \mathrm{min} \times(1 / 1000) \mathrm{g} / \mathrm{mg} \times(1 / 1000) \mathrm{kg} / \mathrm{g} \times 2.205 \mathrm{lb} / \mathrm{kg} \times 60$ $\mathrm{min} / \mathrm{hr} \times 24 \mathrm{hr} /$ day $=0.138 \mathrm{lb} /$ day $\times 107 / 56=0.264 \mathrm{lb} /$ day

- Sludge volume (sludge weight = water weight)

- $0.264 \mathrm{lb} /$ day x $(1 / 62.4) \mathrm{Lb} / \mathrm{ft}^{3}=0.00423 \mathrm{ft}^{3} /$ day

Mn and Al sludge formation

- Use same equation as Fe, but correct for molecular weight

- $\mathrm{Al}=27 \mathrm{~g} / \mathrm{g}$ mole

- $\mathrm{Al}(\mathrm{OH})_{3}=78 \mathrm{~g} / \mathrm{g}$ mole

- $\mathrm{Mn}=55 \mathrm{~g} / \mathrm{g}$ mole

- $\mathrm{Mn}(\mathrm{OH})_{2}=89 \mathrm{~g} / \mathrm{g}$ mole

Alkaline amendment (see Table 3-3 for common alkali amendments)

- Where: $\mathrm{A}=$ required amendment (tons)

$\mathrm{W}=$ amount of waste rock: spoil or refuse (tons)

$\% \mathrm{~S}=\%$ sulfur in waste rock

$\%$ NNP $=\%$ Net Neutralization Potential

$\mathrm{A}=\underline{\mathrm{W} \times \% \mathrm{~S} \times 3.125} \times 1.1$

$\% N N P$

- Example:

Where: $\mathrm{W}=1,000,000$ tons

$\% \mathrm{~S}=2$

$\% N N P=30$

$A=\underline{1,000,000 \times 2 \times 3.125} \times 1.1=229,167$ tons 
Table 3-3

Common Alkaline Amendments

\begin{tabular}{|l|l|}
\hline Amendment & Typical \% NNP \\
\hline Limestone fines <1/4" & $70-95$ \\
\hline Waste lime & $70-95$ \\
\hline Kiln dust & $70-80$ \\
\hline Steel Slag <1/4" & $60-70$ \\
\hline Class C coal ash & 10 to 30 \\
\hline Alkaline spoil & 1 to 30 \\
\hline
\end{tabular}

\section{$\underline{\text { AMD treatment cost vs. change in } \mathrm{pH}}$}

Many AMD impaired streams have a $\mathrm{pH}$ in the range of 2.7 to 5.0. Improvement of stream $\mathrm{pH}$ to the neutral range (6.0-7.5) is often seen as the target for remediation projects. Since the relationship between $\mathrm{pH}$ and acidity is not linear, neither is the relationship between acid load reductions and $\mathrm{pH}$. It is useful to think in terms of titration of a highly buffered solution. The primary buffers in AMD treatment are ferric iron and aluminum. Figure 3-1 illustrates the change in stream $\mathrm{pH}$ with increasing investments in acid load reduction. The curve illustrates a flattening of the line between $\mathrm{pH} 3$ and 4 reflecting the consumption of hydroxide ions by $\mathrm{Fe}(\mathrm{OH})_{3}$ formation. The slope of the curve also decreases between $\mathrm{pH} 4$ and 5 accounting for the precipitation of $\mathrm{Al}(\mathrm{OH})_{3}$. This has serious implications when dealing with public expectations. In highly impaired watersheds, a great deal of investment is normally required before the stream $\mathrm{pH}$ will rise into the neutral range. Thereafter, with metal buffering gone, $\mathrm{pH}$ will rise with very modest alkalinity inputs. 


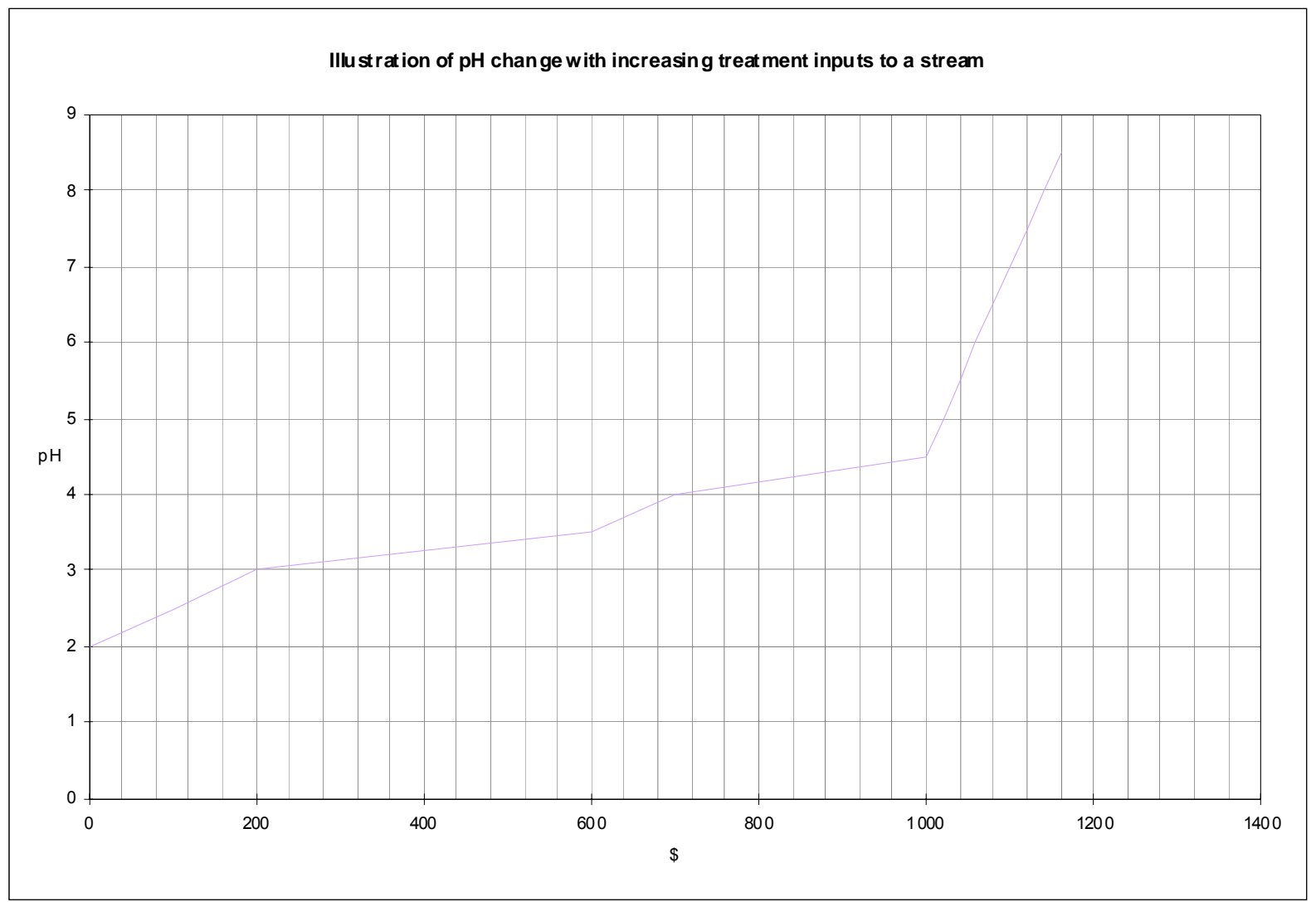

Figure 3-1

pH Change with Increasing Investment in Acid Load Reductions

\section{AMD Passive Treatment System Moved from Sovern Run to Connor Run}

During Phase I, the landowner had verbally agreed to provide site access for carbon soil and water quality sampling at an AMD discharge located on an unnamed tributary to Sovern Run. However, during negotiations on the access agreement, the landowner expressed his desire to move the location of the proposed passive AMD treatment system to the backside of his property to address an AMD seep tributary to Connor Run (Figure 3-2). The rationale for this request was that he did not own the majority of the downstream property traversed by the unnamed tributary to Sovern Run on which an open limestone channel installation was planned, and strongly indicated that the landowner (his father) would not grant property access. He was also interested in the possibility of the project addressing an approximately one-hectare (former sedimentation) pond contaminated with AMD that discharged into Connor Run and the Cheat River (Figure 3-3). 


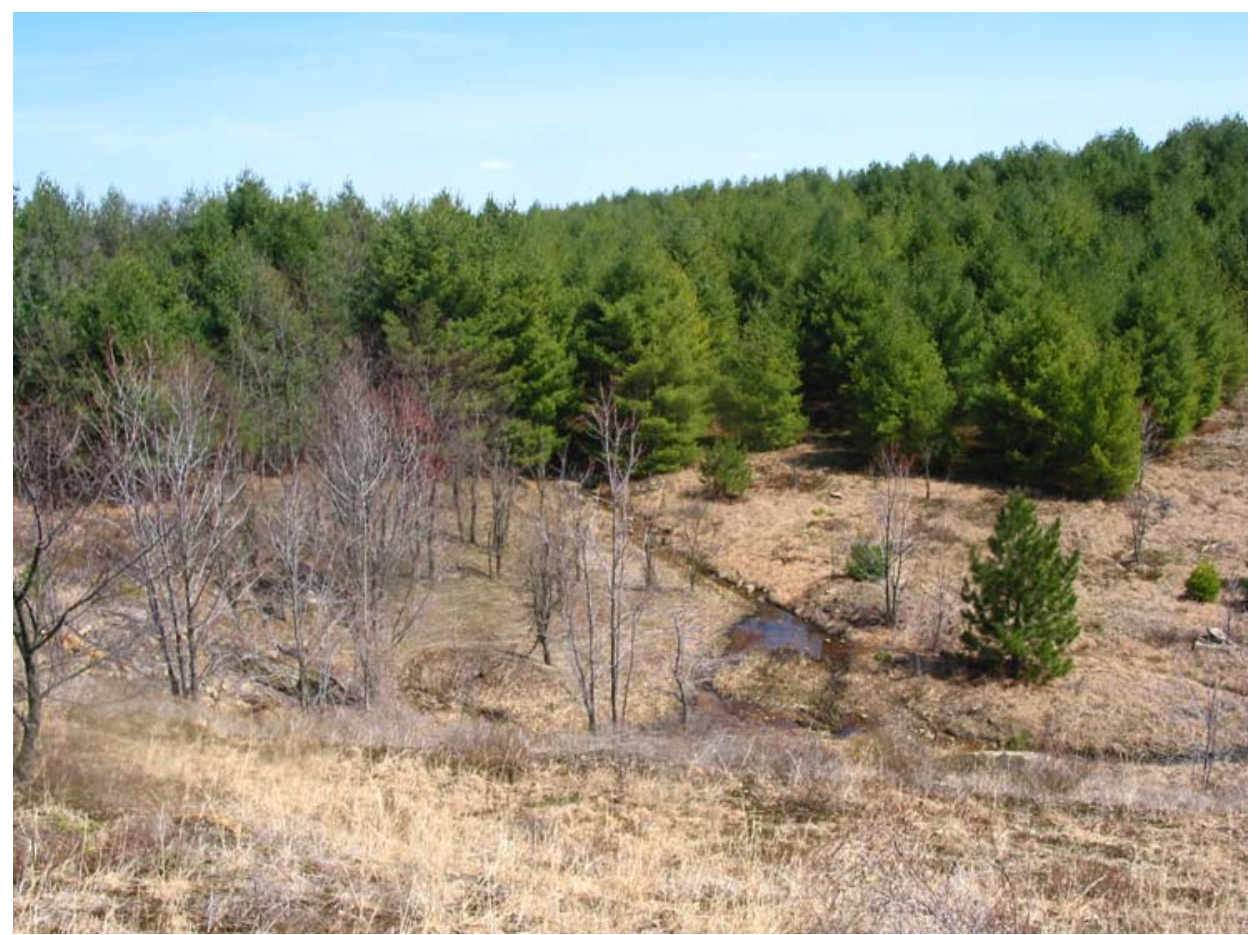

Figure 3-2

Photo of AMD Connor Run Seep Emanating from the Base of Surface Mine Spoil

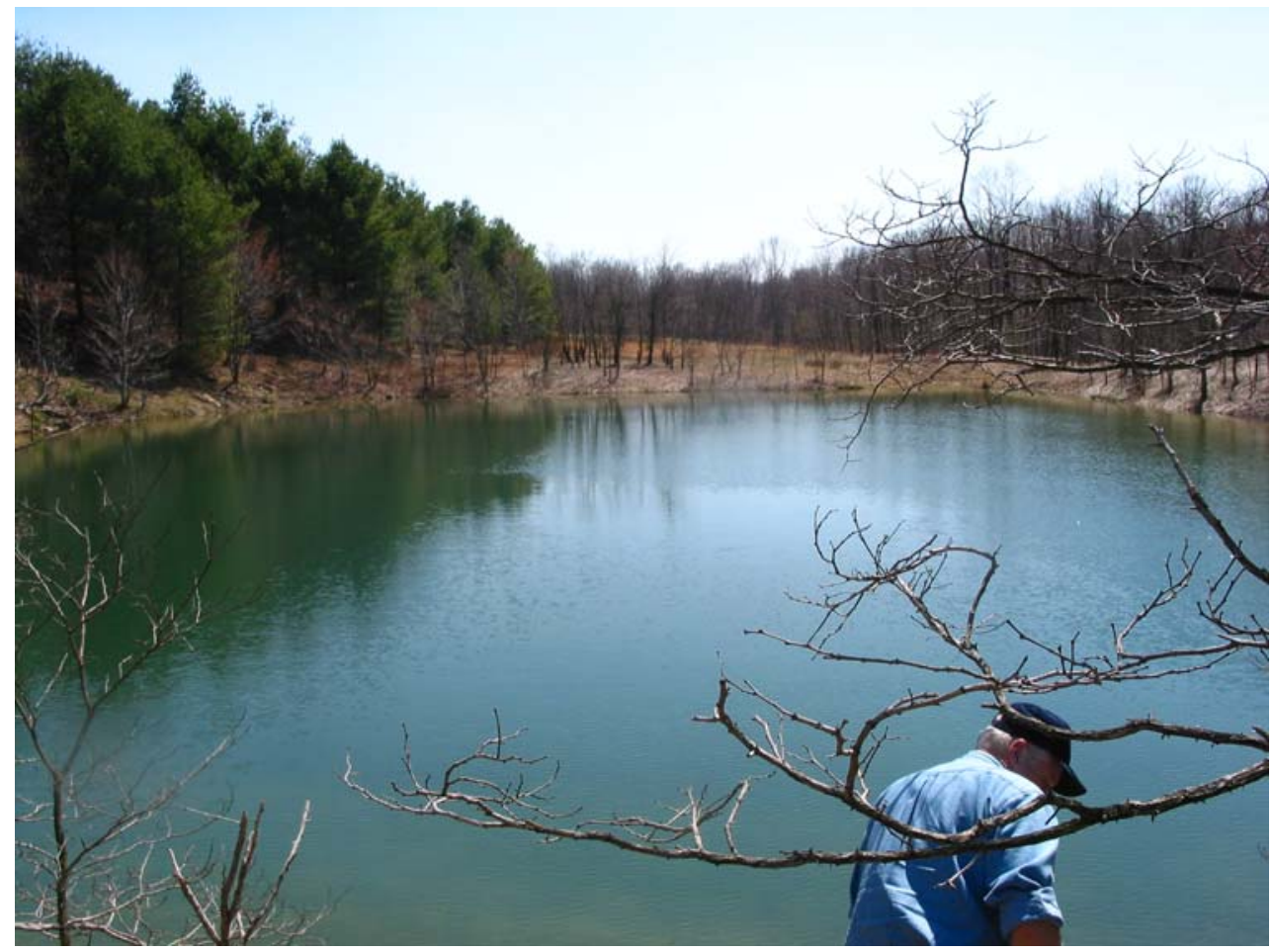

Figure 3-3

AMD Contaminated Pond in Connor Run Drainage 


\section{Baseline Water Quality Monitoring on Connor Run}

As a consequence of moving the location of the passive treatment system, baseline AMD quality data had to be collected from the Connor Run drainage. Figure 3-4 shows the sample locations for the Connor Run site. Due to heavy snowpack and difficult access, only one sample was collected during the first quarter of 2004, in March. The results are shown in Table 3-4. These data indicate AMD quality typical of the Freeport coal seam: moderate acidity, zero alkalinity and high aluminum and manganese concentrations. Water quality sampling results from two AMD locations (pond and seep) and a confluence location on the Connor Run AMD were collected for the first three quarters of 2004 prior to construction of the AMD passive treatment system.

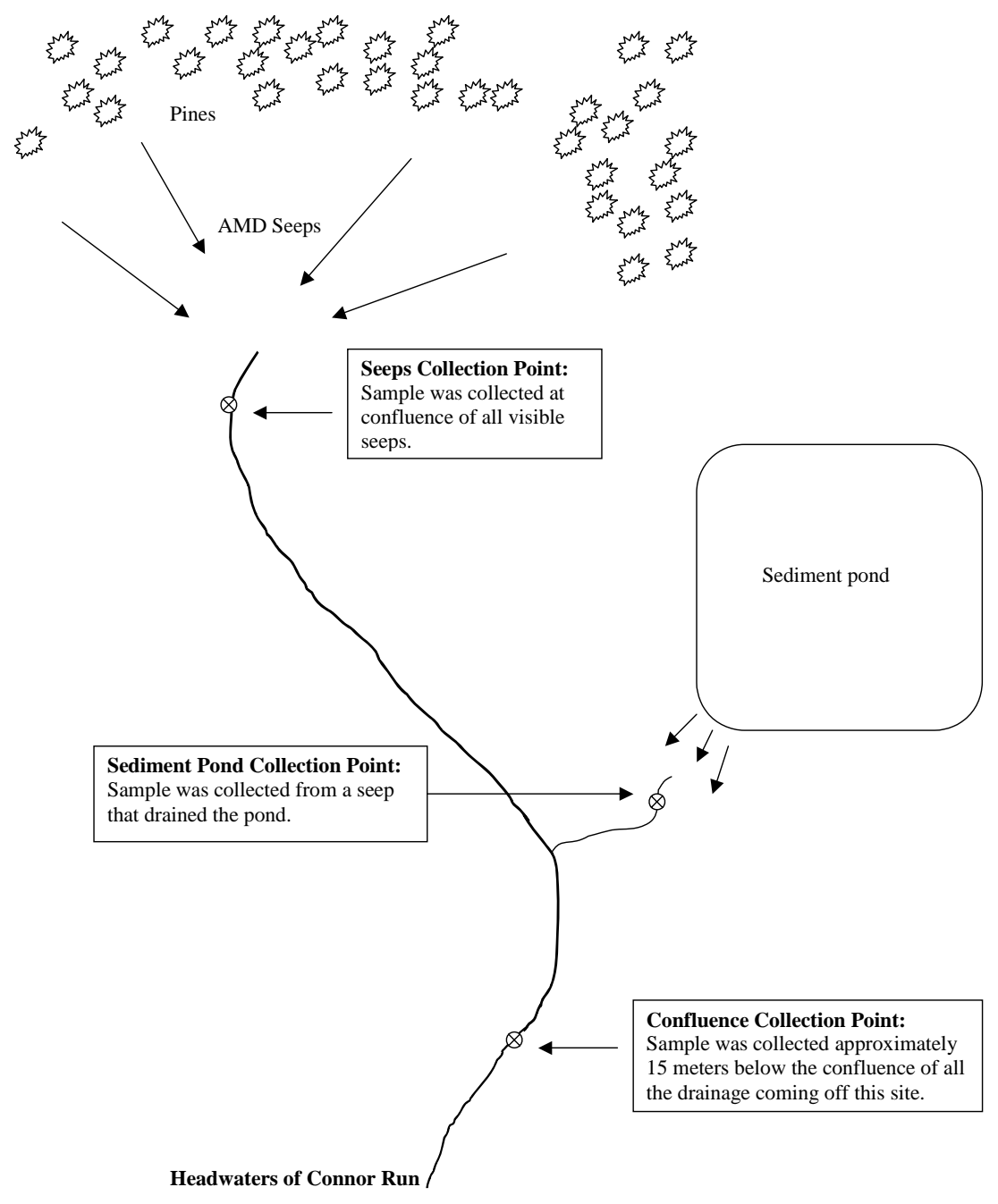

Figure 3-4

Sample Locations for the Connor Run Site 
Table 3-4

March, 2004 Water Quality Analysis Results for Connor Run Drainages

\begin{tabular}{|c|c|c|c|c|}
\hline & Janua & ry, March, 2 & & \\
\hline Sampling Station & Units & Pond & Seep & Confluence \\
\hline date & & 3/23/2004 & $3 / 23 / 2004$ & 3/23/2004 \\
\hline Flow & L/Min & & 11.35 & 13.76 \\
\hline Flow & gpm & & 2.64 & 3.2 \\
\hline Field pH & & & $\mathrm{NM}$ & $\mathrm{NM}$ \\
\hline $\mathrm{pH}$ & & 4.1 & 3.5 & 3.7 \\
\hline acidity & $\mathrm{mg} / \mathrm{l}$ & 114 & 171 & 102 \\
\hline est. acidity & $\mathrm{mg} / \mathrm{l}$ & 104.02 & 211.11 & 118.86 \\
\hline alkalinity & $\mathrm{mg} / \mathrm{l}$ & 0 & 0 & 0 \\
\hline acid-alk & $\mathrm{mg} / \mathrm{l}$ & 114 & 171 & 102 \\
\hline $\mathrm{Mg}$ & $\mathrm{mg} / \mathrm{L}$ & 17.3 & 30.1 & 18.4 \\
\hline $\mathrm{Ca}$ & $\mathrm{mg} / \mathrm{L}$ & 19.2 & 33.8 & 24.9 \\
\hline $\mathrm{Fe}$ & $\mathrm{mg} / \mathrm{L}$ & 0.23 & 28.6 & 11.5 \\
\hline Al & $\mathrm{mg} / \mathrm{L}$ & 17.2 & 11.3 & 10 \\
\hline $\mathrm{Mn}$ & $\mathrm{mg} / \mathrm{L}$ & 3.81 & 9.56 & 5.68 \\
\hline $\mathrm{SO} 4$ & $\mathrm{mg} / \mathrm{L}$ & 224 & 363 & 221 \\
\hline Cond. & $\mu \mathrm{s} / \mathrm{cm}$ & 251 & 757 & 481 \\
\hline \multicolumn{5}{|l|}{ Loadings } \\
\hline Acid Load & $\mathrm{kg} / \mathrm{yr}$ & & 901.20 & 651.59 \\
\hline Fe Load & $\mathrm{kg} / \mathrm{yr}$ & & 150.73 & 73.46 \\
\hline Al Load & $\mathrm{kg} / \mathrm{yr}$ & & 59.55 & 63.88 \\
\hline Mn Load & $\mathrm{kg} / \mathrm{yr}$ & & 50.38 & 36.28 \\
\hline
\end{tabular}

Table 3-5 shows the water quality data that was collected in June, 2004 from the two AMD sources: sedimentation pond and seeps. Another sample was collected approximately 15 meters downstream of the confluence of the seeps and pond on Connor Run. No sampling was conducted during April and May due to scheduling difficulties. These data are similar to the data collected during the previous quarter.

The pond sample was collected from a seep emanating on the downslope side of a former sedimentation pond that collects drainage from a series of subsurface seeps emanating from the toe of the surface mine spoil. The seep sample was collected in the toe of the valley that drains a large portion of the former surface mine. Depending on antecedent precipitation conditions the pond and seep samples can represent a combination of both surface runoff and subsurface flow. The data indicates water quality typical of AMD contamination associated with the Freeport coal seam: relatively low $\mathrm{pH}$ and high acidity and metal concentrations. The low iron concentration in the pond reflects the results of oxidation causing precipitation. 
Table 3-5

Water Quality Data for June, 2004

\begin{tabular}{|c|c|r|r|r|}
\hline \multicolumn{5}{|c|}{ Quarter 2 Sampling } \\
\hline Sampling & & & & \\
Station & Units & Pond & Seep & Confluence \\
\hline date & & $06 / 18 / 04$ & $06 / 18 / 04$ & $06 / 18 / 04$ \\
Flow & $\mathrm{gpm}$ & $\mathrm{NM}$ & 4 & 20.08 \\
Flow & $\mathrm{L} / \mathrm{Min}$ & $\mathrm{NM}$ & 15.1 & 76.0 \\
Field $\mathrm{pH}$ & & 3.7 & 3 & 3.5 \\
$\mathrm{pH}$ & & 3.7 & 3 & 3.4 \\
acidity & $\mathrm{mg} / \mathrm{L}$ & 135 & 197 & 58 \\
est. acidity & $\mathrm{mg} / \mathrm{L}$ & 104.47 & 222.67 & 67.88 \\
alkalinity & $\mathrm{mg} / \mathrm{L}$ & 0 & 0 & 0 \\
acid-alk & $\mathrm{mg} / \mathrm{L}$ & 135 & 197 & 58 \\
acid load & $\mathrm{kg} / \mathrm{yr}$ & $\mathrm{NM}$ & 1573.07 & 2324.95 \\
$\mathrm{Mg}$ & $\mathrm{mg} / \mathrm{L}$ & 17.4 & 37 & 11 \\
Ca & $\mathrm{mg} / \mathrm{L}$ & 18.9 & 39.5 & 24.2 \\
Fe & $\mathrm{mg} / \mathrm{L}$ & 0.59 & 17.6 & 5.17 \\
Al & $\mathrm{mg} / \mathrm{L}$ & 15.9 & 15.7 & 4.15 \\
Mn & $\mathrm{mg} / \mathrm{L}$ & 3.99 & 12.9 & 3.59 \\
SO4 & $\mathrm{mg} / \mathrm{L}$ & 251 & 509 & 159 \\
Cond & $\mu \mathrm{s} / \mathrm{cm}$ & 489 & 1460 & 480 \\
\hline
\end{tabular}

The results of the water sampling for July and September, 2004 are shown in Table 3-6. No water quality sampling was conducted during August, as the seep dried up. In July and September flow volumes were too low to measure. The pond sample location was collected along the perimeter of a pond that collects drainage from several subsurface seeps. The seep sample was collected at a point in the upper drainage in which all the surface and subsurface seeps were combined. These were the last samplings taken prior to construction of the passive treatment system. 
Table 3-6

Water Quality Data—July and September, 2004

\begin{tabular}{|c|c|r|r|r|r|r|}
\hline \multicolumn{7}{|c|}{ July, August, September Sampling } \\
Sampling & & & & & \\
Station & & Pond & Seep & Downstream & Pond & Seep \\
\hline date & & $7 / 21 / 2004$ & $7 / 21 / 2004$ & $7 / 21 / 2004$ & $9 / 16 / 2004$ & $9 / 16 / 2004$ \\
Flow & $\mathrm{gpm}$ & $\mathrm{NM}$ & 0.5 & 3.1 & $\mathrm{NM}$ & 2.82 \\
Flow & $\mathrm{L} / \mathrm{Min}$ & $\mathrm{NM}$ & 1.89 & 11.73 & $\mathrm{NM}$ & 10.67 \\
Field pH & & 3.7 & 3 & 3.3 & & 3 \\
$\mathrm{pH}$ & & 3.7 & 2.9 & 3.2 & 3.7 & 2.9 \\
acidity & $\mathrm{mg} / \mathrm{l}$ & 134 & 366 & 123 & 151 & 219 \\
est. acidity & $\mathrm{mg} / \mathrm{l}$ & 146.30 & 659.76 & 117.04 & 101.3 & 301.79 \\
alkalinity & $\mathrm{mg} / \mathrm{l}$ & 0 & 0 & 0 & 0 & 0 \\
acid-alk & $\mathrm{mg} / \mathrm{l}$ & 134 & 366 & 123 & 151 & 319 \\
acid load & $\mathrm{tons} / \mathrm{yr}$ & $\mathrm{NM}$ & 1.52 & 3.18 & & \\
Mg & $\mathrm{mg} / \mathrm{L}$ & 20.4 & 63.5 & 24.7 & 16.4 & 81.2 \\
Ca & $\mathrm{mg} / \mathrm{L}$ & 22.2 & 61.8 & 64 & 20.9 & 80.6 \\
Fe & $\mathrm{mg} / \mathrm{L}$ & 0.62 & 31.1 & 6.68 & 0.32 & 25.8 \\
Al & $\mathrm{mg} / \mathrm{L}$ & 17 & 80.9 & 9.15 & 15.6 & 19.4 \\
Mn & $\mathrm{mg} / \mathrm{L}$ & 43.1 & 18.6 & 7.33 & 3.61 & 25.3 \\
SO4 & $\mathrm{mg} / \mathrm{L}$ & 250 & 901 & 436 & 202 & 735 \\
Cond. & $\mathrm{Hs} / \mathrm{cm}$ & & & & & 2080 \\
\hline
\end{tabular}

\section{AMD Treatment System Design}

The AMD passive treatment system planned for the original location was to be a simple limestone channel for a single AMD discharge from the old Bull Run Mine known as seep 72. The new site on Connor's run was much more complex, with multiple discharges, some of which were discrete seeps and others diffuse seeps, as well as AMD upwelling in the stream channel. The Connor Run site also had much less flow than seep 72 and roughly one-tenth the acid load.

The pre-construction project site consisted of a series of seeps that emanate at the toe of a spoil fill slope that is semi-circular in shape. AMD was clearly generated in the spoil and flowed down dip along the mine pavement to discharge around the head of the uppermost reach of Connor Run. These toe drainages emptied into an existing channel that conveyed surface flow from the upper portion of the site during the wetter parts of the year. The project site also had a pond that was fed by a series of subsurface springs located further south of the seeps.

Between March and the finalization of AMD system designs in July 2004 the project team had the opportunity to sample the Connor Run site twice, in March and June. The sampling interval was constrained by the need to survey and develop drawings for the site bid package and to develop construction subcontracts. While less than desirable, the interval was the longest sampling interval that could be used for the conceptual AMD system design, which is shown in Figure 3-5. 


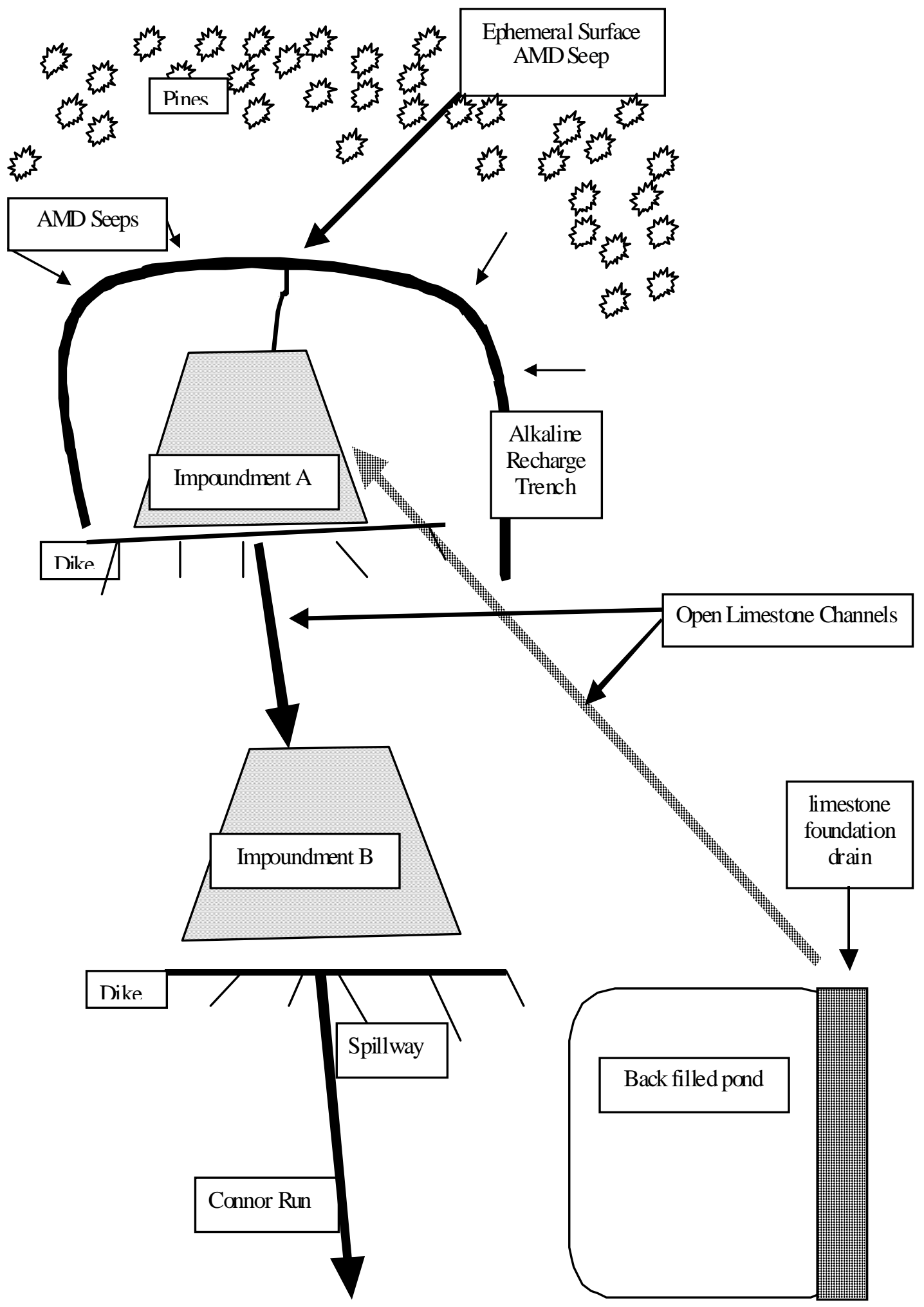

Figure 3-5

Conceptual Design for Passive Treatment System on Connor Run 
When conceptually designing the passive treatment system, the baseline chemical and physical parameters shown in Table 3-7 were used. These data, collected during March, 2004, are from the seeps identified on Figure 3-5. Also considered was Connor Run monitoring data immediately downstream of the sediment pond indicated on Figure 3-4 to estimate total subsurface AMD (flow) inputs to Connor Run in the project area.

Table 3-7

Baseline Parameters Used in Conceptual Design/Sizing of Passive Treatment System

\begin{tabular}{|cccccc|}
\hline $\begin{array}{c}\text { Flo } \\
\text { (L/Min }\end{array}$ & $\mathrm{pH}$ & Calculated & Iron & Aluminum & Manganese \\
\hline 13.76 & 3.5 & 211 & 28.6 & 11.3 & 9.56 \\
\hline
\end{tabular}

Flow in the upper reach of Connor Run increased by a factor of between 1.2 and 6.2 between the upper seep and the lowermost stream sample. There were no other surface sources reaching Connor Run along this reach indicating significant subsurface flow. The goal was to intercept and treat this AMD. For design purposes, the seep AMD was use (see Table 3-7) as the best representation of AMD quality. The data indicate that the AMD was acidic, with low $\mathrm{pH}$ significant iron, aluminum and manganese. The treatment objective was to remove acidity in the form of $\mathrm{H}$ protons, iron and aluminum ions. It was not intended to affect manganese concentrations since its precipitation involves a slow oxidation step subsequent to neutralization. The plans were developed around AMD capture, alkalinity addition and oxidation of ferrous to ferric ion. Ferric hydroxide precipitate would form above $\mathrm{pH} 3.2$ while aluminum hydroxide would precipitate above $\mathrm{pH} 4.2$.

Pre-construction sampling and site inspection identified three apparent sources of AMD:

- The surface seep and ephemeral stream originating in the pine trees.

- Subaerial, diffuse seepage along the pit floor at the headwaters of Connor Run.

- Subaerial, subaqueous seeps feeding the sediment pond.

Since it was impossible to isolate subaerial flows and measure its water quality, the seep water was used to estimate AMD quality throughout the property and used the downstream flows to estimate loadings.

\section{AMD Treatment Technologies Selected}

The four treatment technologies chosen are summarized below.

1. Alkaline Recharge Trench (ART). This method was developed in the Midwest to address AMD running along surface mine pit floors with shallow gradients. An ART consists of a trench dug through spoil to the pit floor normal to the groundwater flow path. Lime or kiln dust is placed on the floor and covered on three sides with coarse limestone. The limestone creates a preferred flow path so that AMD remains in contact with the lime as it moves down 
gradient. ART are sized primarily to reach the pit floor and to intercept all AMD flow pathways.

2. Open Limestone Channel (OLC). Open limestone channels were designed for steep gradients $(>10 \%)$ and low iron concentrations. They work best in low $\mathrm{pH}$ water. Although the channel gradients were much less than $10 \%$, the OLCs was used because they have proven to be one of the most reliable and cost effective means for acidity reduction over a wide range of conditions. Unlike anoxic limestone drains and vertical flow wetlands, they tolerate a wide range in ferric/ferrous ratios and high aluminum concentrations. Two OLCs were used in the project.

3. Limestone Foundation Drain (LFD). This method is a French drain used to collect below ground AMD and direct it to a treatment area. Using limestone results in acid neutralization. However, since subaerial flows are difficult to measure there was no way to predetermine the effect of the LFD.

4. Impoundments. Sometimes called aerobic wetlands, impoundments are open water bodies that encourage oxidation of ferrous to ferric ion while capturing resulting ferrihydrite and gibbsite precipitates. There was room to install two impoundments on the project site. The stream gradient and pre-construction landscape facilitated installation of two impoundments in series.

\section{Passive Treatment System Components}

Following are the rationales and methodologies used for the passive treatment technology applied in this project.

\section{Alkaline Recharge Trench}

The valley area at the head of the passive treatment system is predominantly acidic mine spoil remaining from the abandoned surface mining operation. The ground water flows through this unconsolidated material and picks up acidity. An ART is planned to be excavated along the toe of the valley fill down to the pavement (a slang term for the bedrock typically found at the base of the coal seam) and backfilled with a mixture of cement kiln dust and limestone in an effort to treat the groundwater before it surfaces. Figure 3-6 demonstrates how the trench functions. 


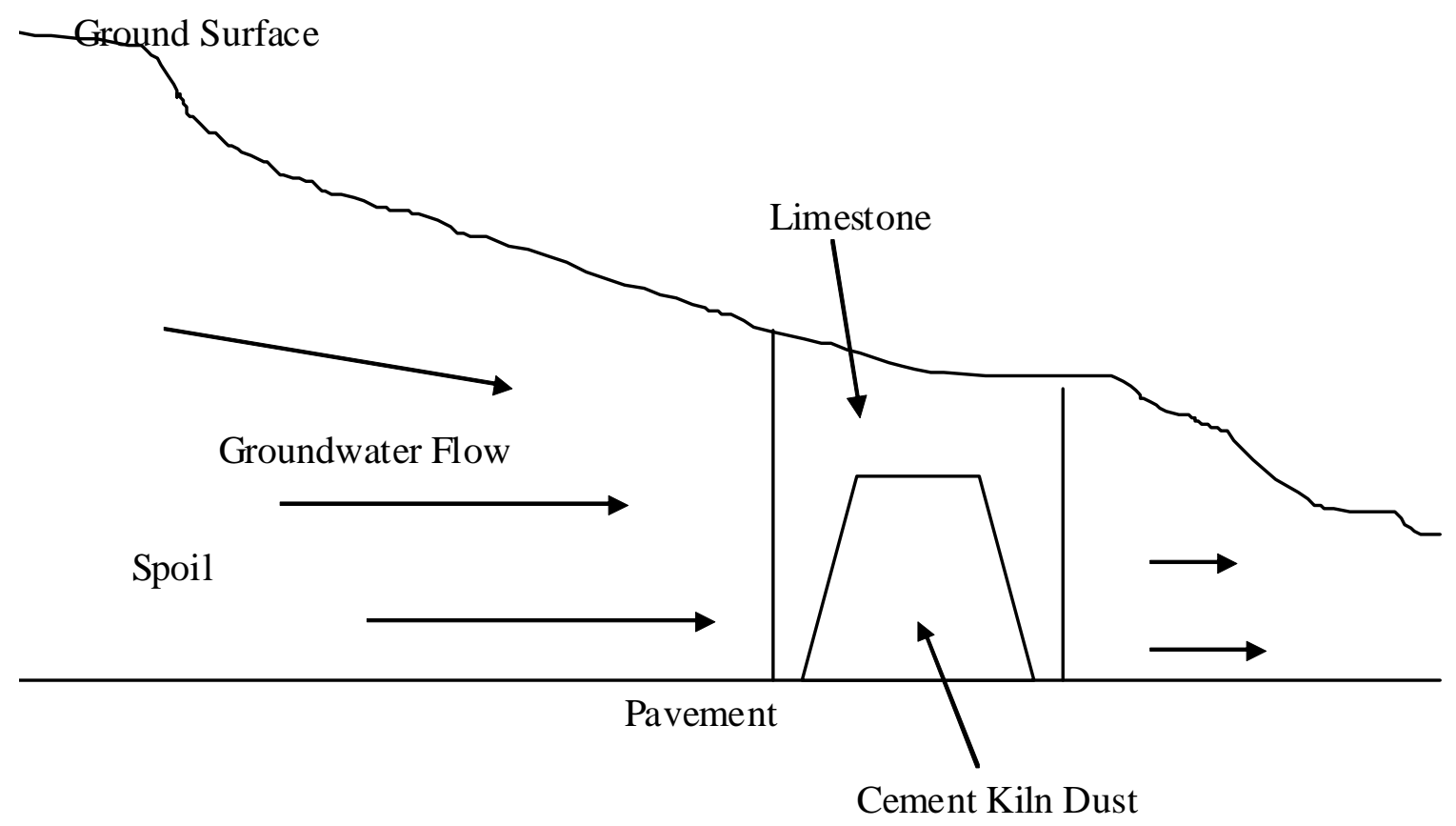

Figure 3-6

Alkaline Recharge Trench (ART) Cross Section

The ART will be built to collect and neutralize a number of AMD seeps present throughout the head of the valley. The ART is designed to collect acidic subsurface flow from the spoil, take up little area and is relatively inexpensive to construct compared to other AMD treatment modules. For example, it would have been more expensive and problematic to construct a vertical flow wetland due to constrained area and shallow depth of bedrock.

Based on field measurements, two ARTs are to be constructed 150 feet on either side of the small tributary totaling approximately 300 feet in length. It is anticipated the ARTs will be constructed approximately 2-3 meters wide and approximately 2.5 meters deep.

\section{Open Limestone Channel}

At this site, the installation of open limestone channels act as a means of conveyance from one treatment cell to the next. They are also designed to act as retention/treatment structures. There will be two open limestone channels constructed at this project site. The first OLC conveys the water from Impoundment A collecting the seeps from the ARTs. The second channel will convey the AMD springs that feed the former sedimentation pond that will be collected by the limestone foundation drain to Impoundment A. Open limestone channels are commonly used for AMD treatment because they are inexpensive to construct, and even though they eventually fill with metal sludge, still convey and treat water. 


\section{Limestone Foundation Drain}

The project site contains a former sedimentation pond that is fed by a series of subsurface springs. In order to treat these discharges, it is necessary to construct a limestone foundation drain to collect the springs and channel them as high into the treatment system as possible. To ensure proper operation and construction of the limestone foundation drain, the pond is to be drained and compacted/backfilled in an effort to ensure preferential infiltration flow into the drain. The limestone foundation drain was incorporated because of the unknown depth of the AMD springs within the sedimentation pond.

\section{Impoundments}

Two retention structures were designed for the purpose of precipitating and retaining metals. The first retention structure (Figure 3-5, Impoundment A) will be located below the confluence of seeps from the ARTs. This impoundment will also collect water from the limestone foundation drain. The second impoundment (Figure 3-5, Impoundment B) will be located just above the project outfall to provide precipitation and retention for any metals remaining in the effluent. The second impoundment will be constructed by building an earthen dam across a lower section of the existing channel.

\section{Construction of the AMD Passive Treatment System}

The construction of the AMD passive treatment system started on August 25, 2004 and was completed on September 29, 2004. The construction of the AMD passive treatment design utilized a buried trench of limestone and cement kiln dust to intercept the mine water flowing subsurface through the mine soil and treating it by adding alkalinity. The existing pond was also drained and backfilled in order to convey, via an open limestone channel, the AMD seeps feeding it into a shallow impoundment at the bottom end of the AMD treatment system (Impoundment B). This impoundment, which collects the drainage from the trench, as well as the backfilled pond, then discharges into Connor Run.

Figure 3-7 shows a schematic depicting the final passive AMD treatment system constructed on Connor Run drainage. Figures 3-8 through 3-12 are photos taken during construction and Figures 3-13 and 3-14 are post-construction photos. 


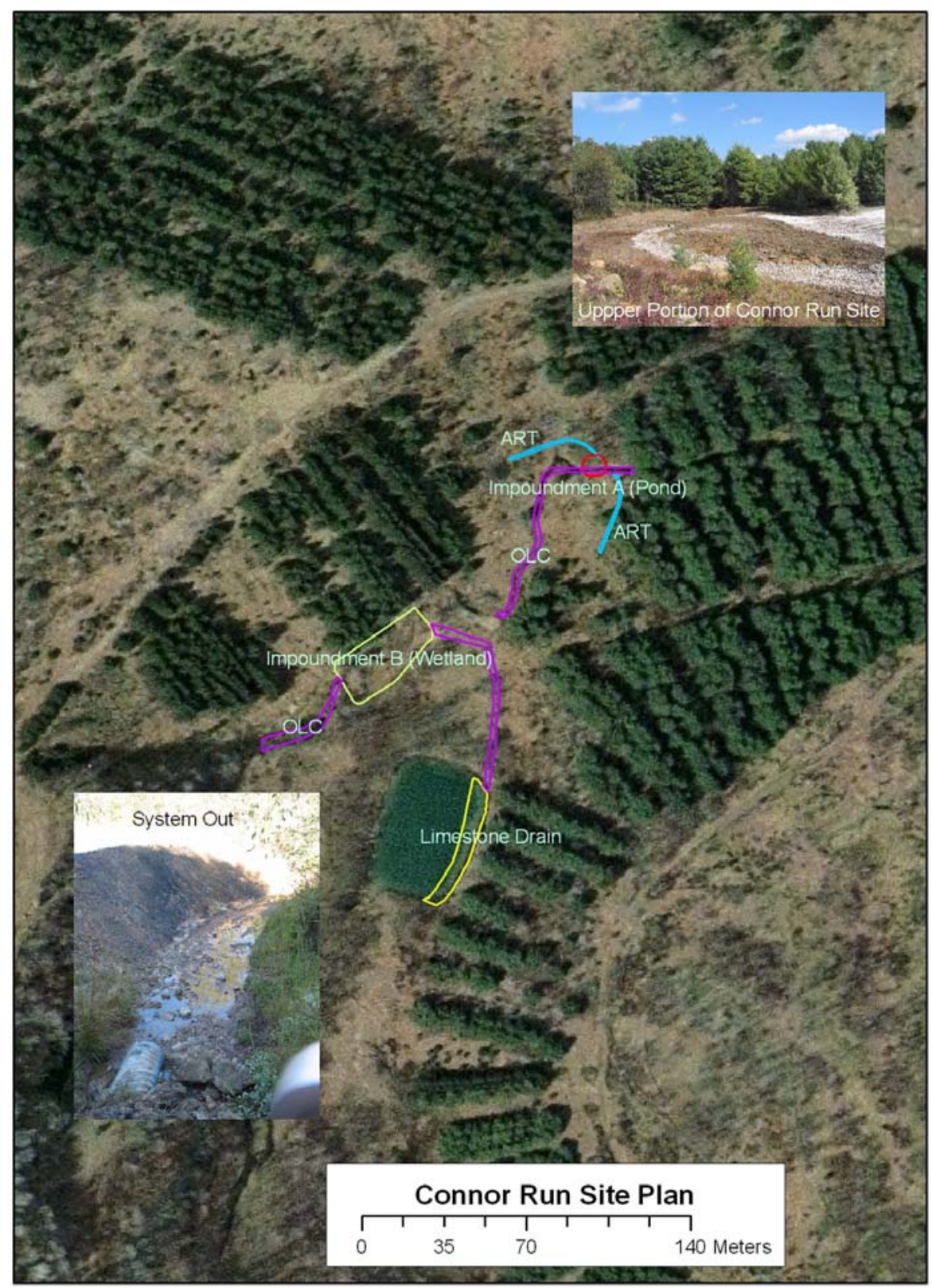

Figure 3-7

Schematic Depicting Final Passive AMD Treatment 


\section{Construction Photos}

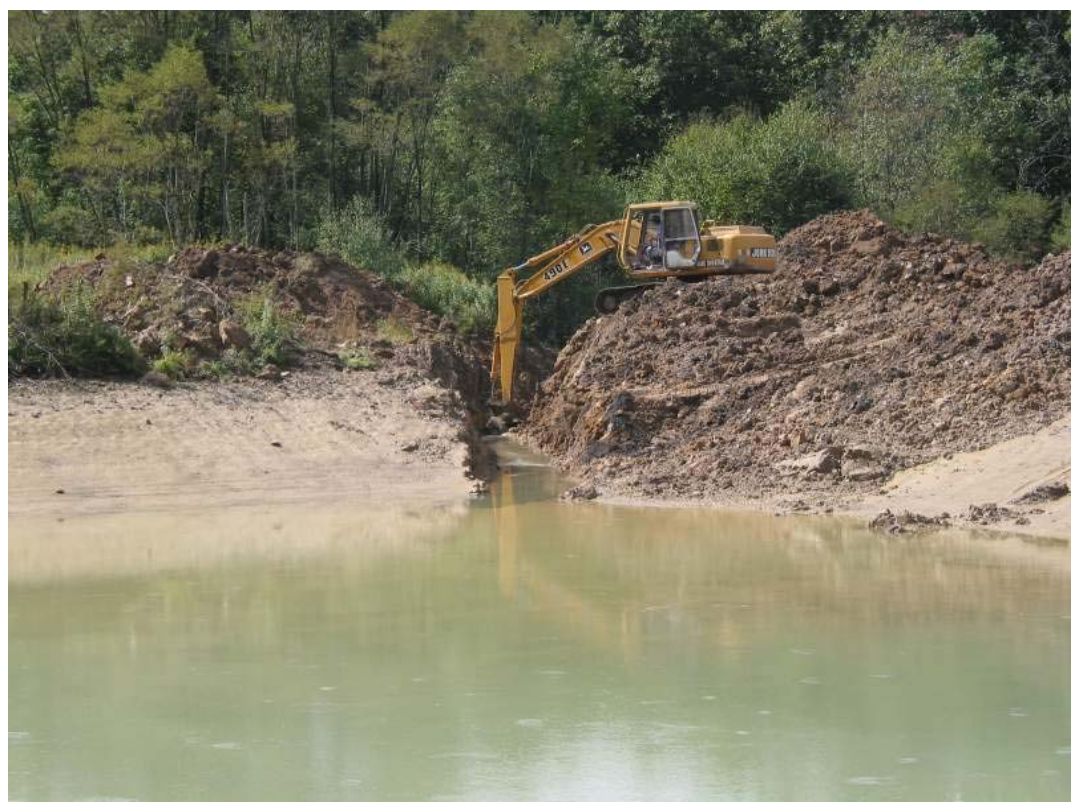

Figure 3-8

Backhoe Breaching Dike of Former Sedimentation Pond

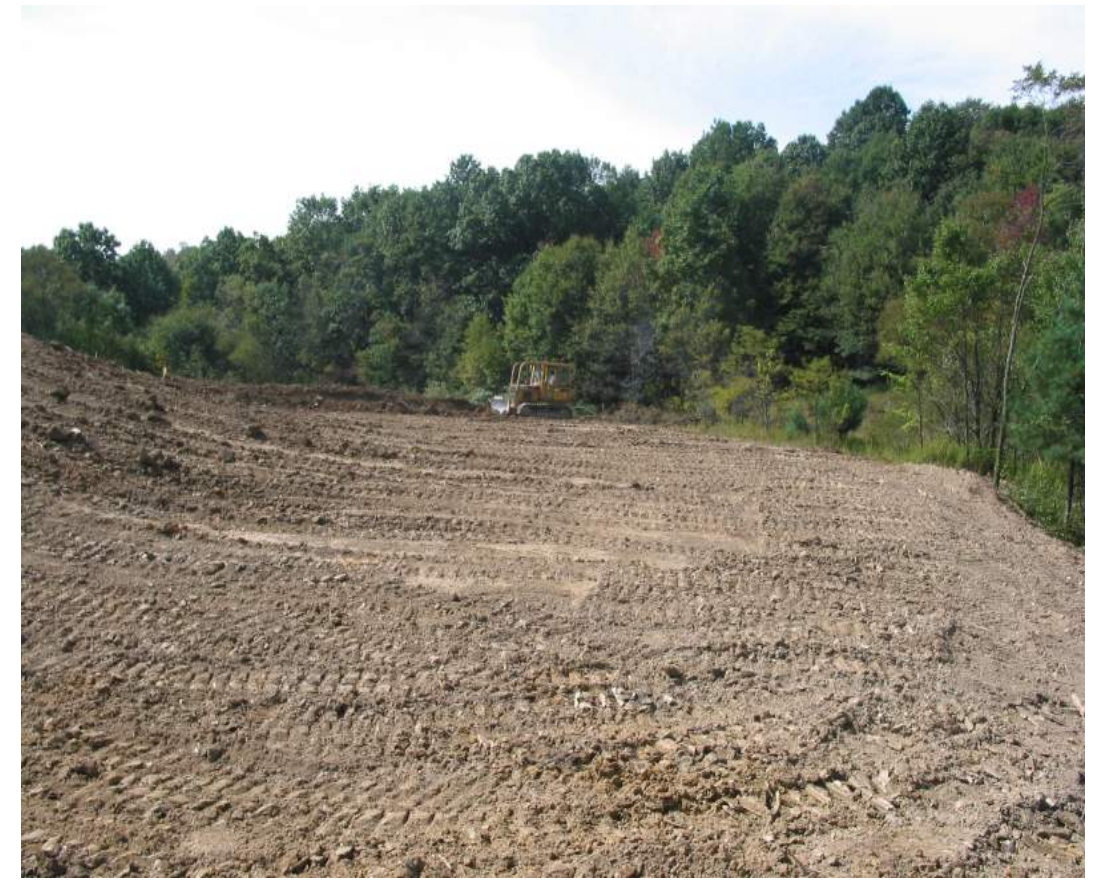

Figure 3-9

Backfilling and Compacting Sedimentation Pond 


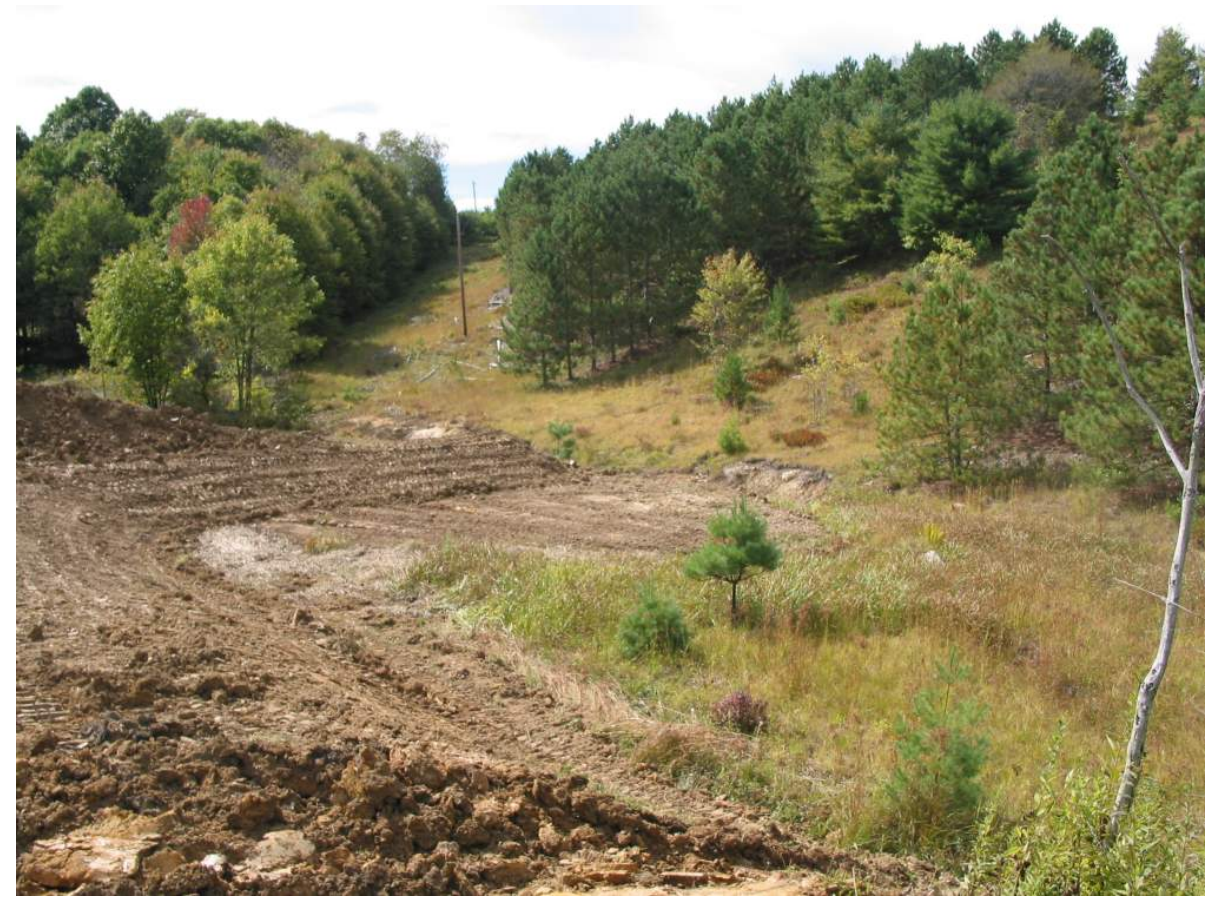

Figure 3-10

Construction and Compaction of Impoundment B Dike

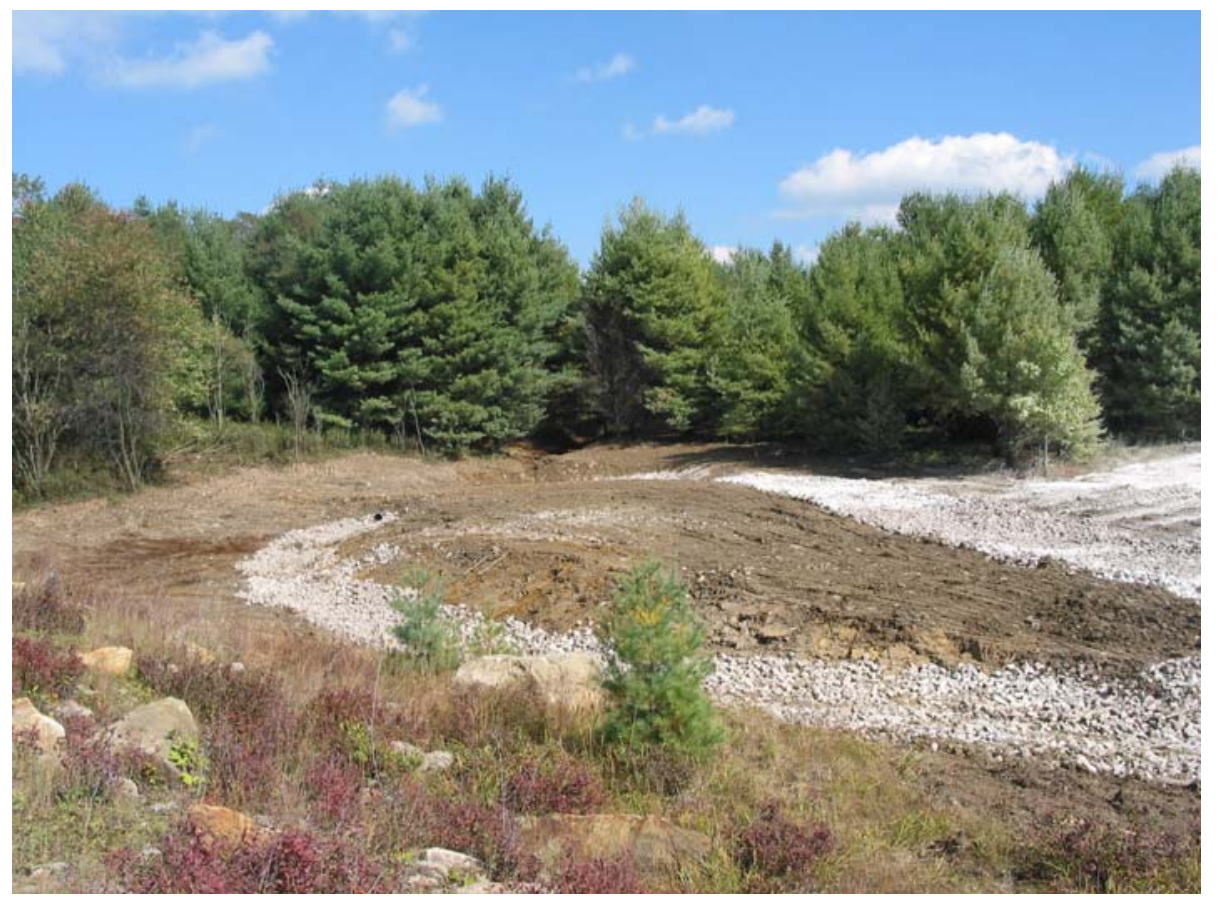

Figure 3-11

Location of Impoundment A and ART 


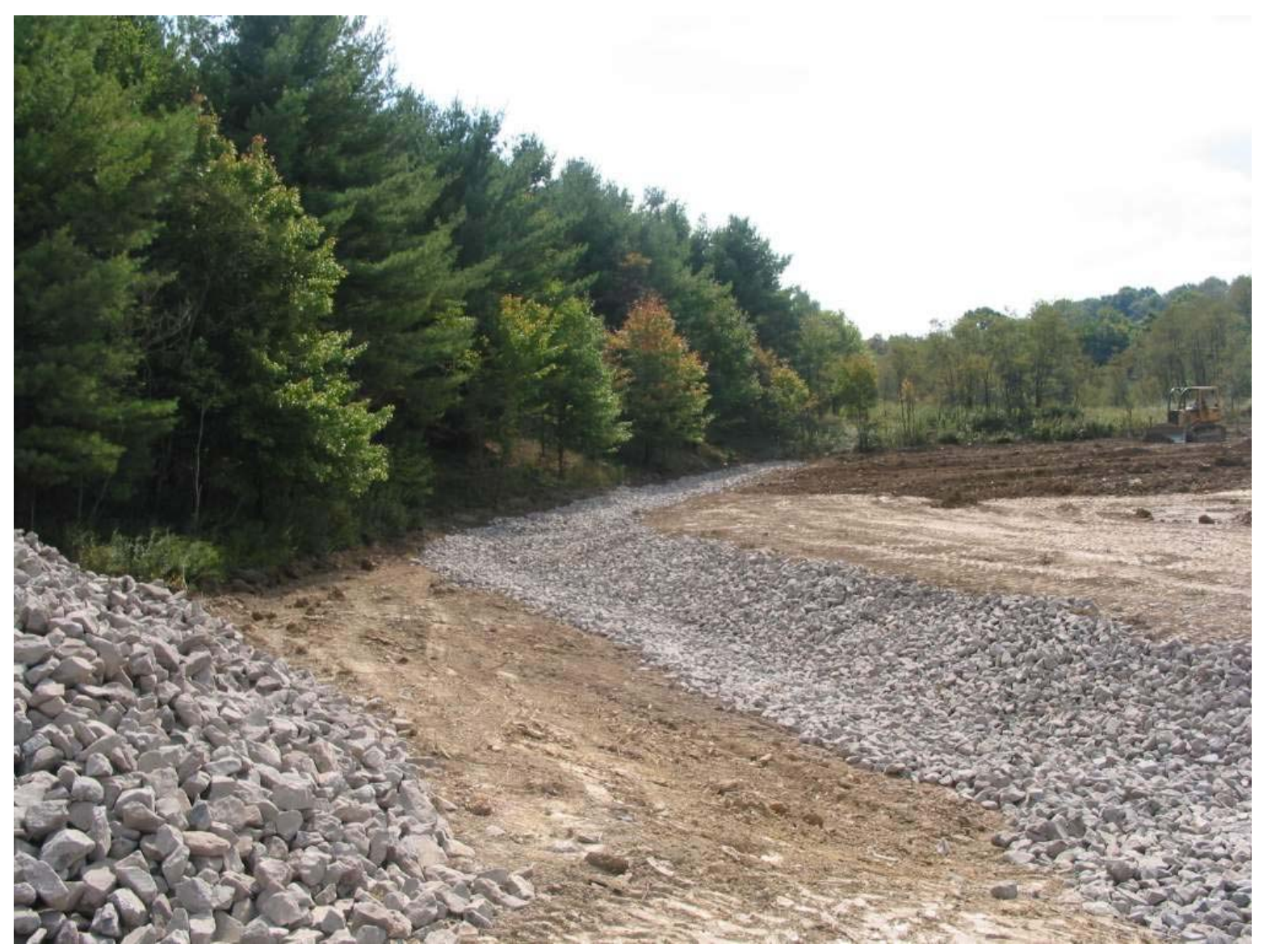

Figure 3-12

Backfilled Sediment Pond and Open Limestone Channel 


\section{Post-Construction Photos}

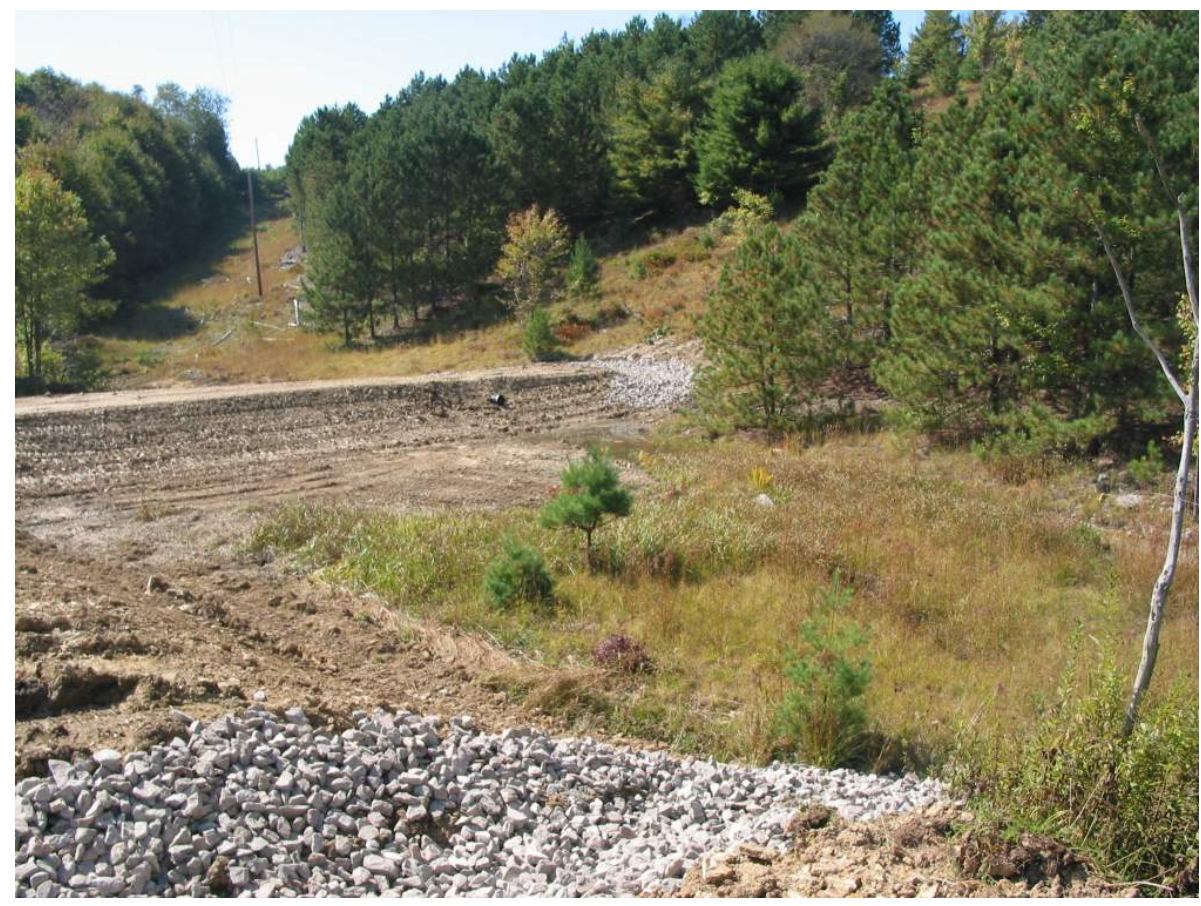

Figure 3-13

Completed Impoundment B and OLC Conveying AMD from Former Pond

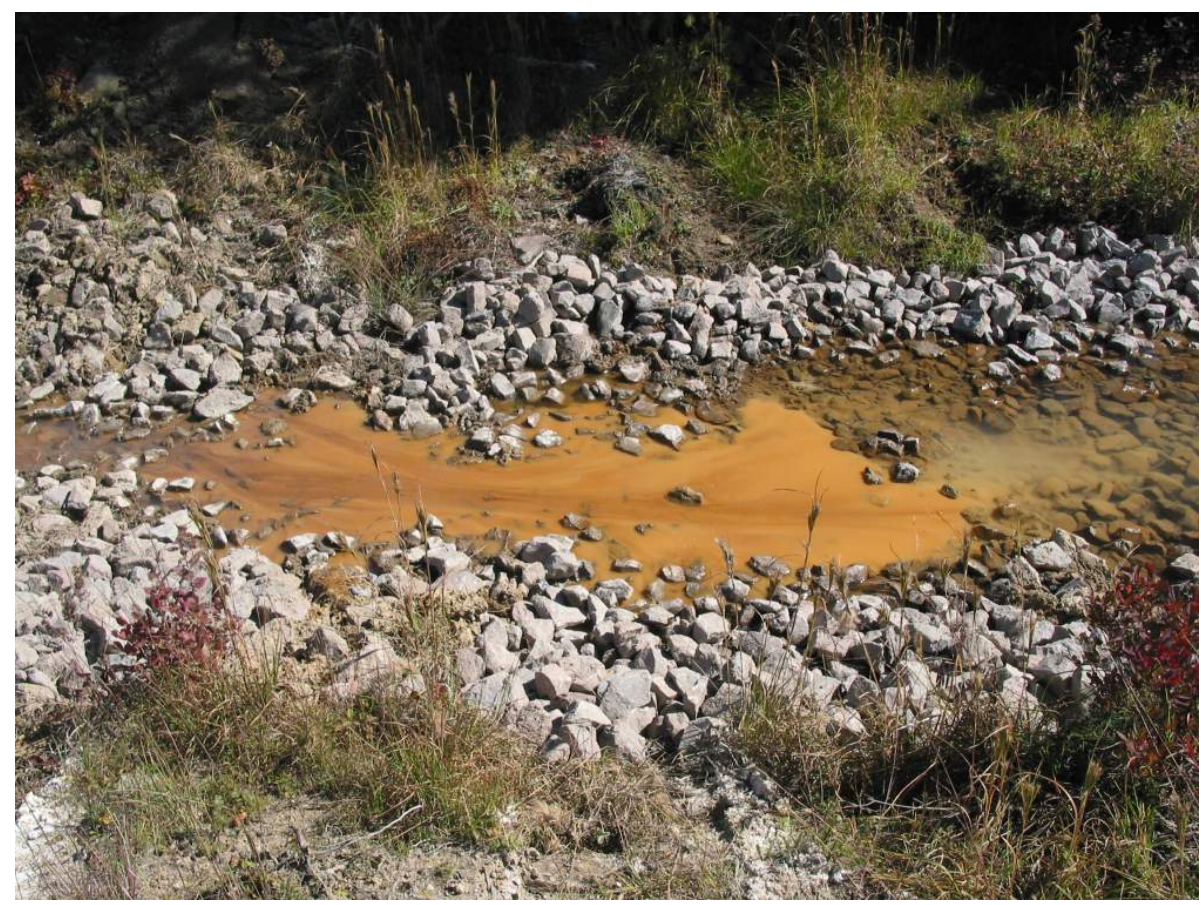

Figure 3-14

AMD Discharge from Impoundment A Showing Fe and Al Precipitation 
Several site conditions were incurred during the survey and construction phase that were not anticipated in the conceptual design, requiring modifications to the final system configuration. The springs feeding the pond were determined to be at the same elevation as Impoundment A. In order to achieve positive flow, the open limestone channel had to be shifted into Impoundment $\mathrm{B}$, requiring additional excavation. Moreover, due to the elevation of the springs, additional excavation was required to properly construct and compact the limestone foundation drain. Additional modifications included reconfiguring the Alkaline Recharge Trench and upper retention pond (Impoundment A) to accommodate weak soil conditions and a shallow bedrock crop respectively. These factors increased construction costs due to the additional amount of soil that was required to be moved to properly construct the limestone foundation drain and open lime stone channel. Construction costs are shown in Table 3-8.

Table 3-8

As Built Dimensions and Costs for Passive Treatment System

\begin{tabular}{|c|c|c|c|c|c|c|c|}
\hline Item & Length & Width & Depth & Tons Limestone & Tons CKD & & Cost \\
\hline Mobilization/Demobilization & & & & & & $\$$ & 3,000 \\
\hline LS 1 & 18 & 18 & 3 & & 25 & $\$$ & 2,000 \\
\hline ART 1 & 200 & 4 & 4 & 150 & 550 & $\$$ & 26,711 \\
\hline OLC 1 & 160 & 6 & 4 & 170 & & $\$$ & 6,800 \\
\hline OLC 2 & 150 & 5 & 4 & 127 & & $\$$ & 6,000 \\
\hline FD 1 & 50 & 6 & 6 & 40 & & $\$$ & 5,463 \\
\hline Imp "A" & 50 & 15 & 2 & 35 & 15 & $\$$ & 5,086 \\
\hline Imp "B" & 100 & 50 & 3 & & & $\$$ & 5,086 \\
\hline Excavation (3,958 cy @3.50cy) & & & & & & $\$$ & 13,854 \\
\hline TOTAL & & & & 522 & 590 & $\$$ & 74,000 \\
\hline
\end{tabular}

\section{Task 2: Reforest and Enhance Carbon Sequestration Project Site}

\section{Overview}

Task 2 involved developing carbon sequestration credits by clearing and grubbing a thirty-acre plot and then amending the soil with fly ash from Allegheny Energy's bituminous coal-fired Albright Power Station. Five of the six plots were to receive an application of class F fly ash to neutralize soil acidity. The remaining plot was to serve as the control. Five commercial hardwood tree species were going to be planted in the six plots and growth and survival was to be measured. Vegetative and soil carbon were to be measured and compared to baseline measurements (Phase I) to determine the amount of carbon sequestered.

There were several tasks associated with this portion of the project:

- Building an access road for transporting the ash from the Albright Power Station to the project site.

- Analyzing and preparing the soil for the ash amendment.

- Clearing and reforesting the project site with hardwood seedlings. 
- Measuring and analyzing the performance of the seedlings.

- Measuring the carbon soil and vegetative matter content.

Due to cost and weather issues, the first three tasks were only partially completed. The last two tasks were discontinued when the project scope was changed. Each of the tasks is discussed in detail below.

\section{Building An Access Road for Transporting Ash}

The original plans called for constructing a 2,200 foot haul road to the project site to transport the ash gathered from the Albright Power Station. Construction of the road began in October, 2004. If the autumns of 2004 proved as dry and mild as the previous two autumns, ash haulage would only require minimal road preparation and could proceed through the fall and winter. The weather turned wet and snowy, however, and the adverse weather and saturated soil conditions halted the construction of the road. The partially completed road is shown in Figure 3-15. In 2005, due to cost concerns, the decision was made to terminate the reforestation portion of the project, so the access road was never completed.

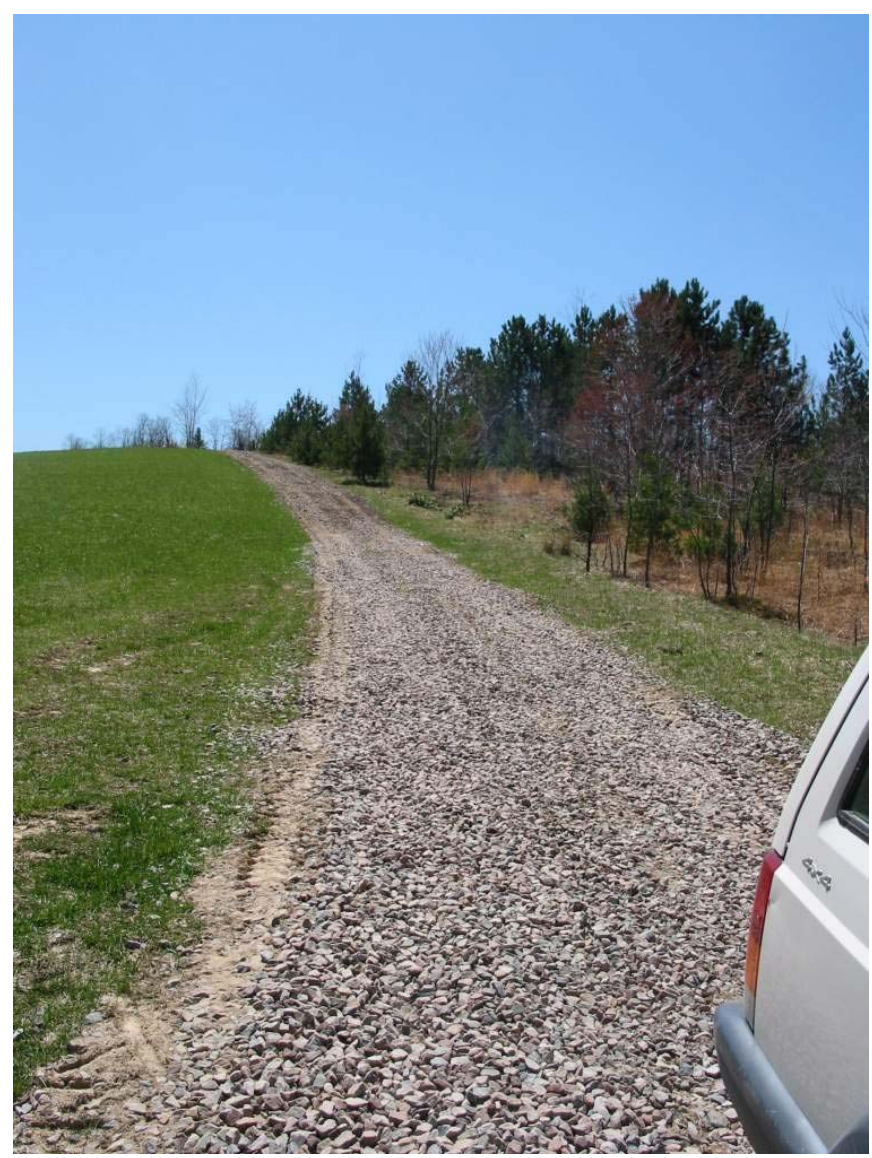

Figure 3-15

Partially Constructed Access Road to Reforestation Site 


\section{Analyzing and Preparing the Soil for Ash Amendment}

The tree planting plots had an acidic, compacted, clayey soil that was not suitable for productive forest development. It was determined that adding fly ash to the soil would provide needed lime while improving soil structure. The beneficial effect of fly ash amendments on mine soil reclamation is well documented (Keefer ${ }^{3}$ et al., 1983, Capp ${ }^{4}, 1978$, Bhumbla ${ }^{5}$ 1991, and Singh ${ }^{6}$ et al. 1992). Adding fly ash to mine soils may reduce the undesirable chemical and physical conditions, such as acidity, compaction and low water holding capacity, present in mine soils. A 1995 study by Dhaliwal ${ }^{7}$ et al. demonstrated that even after 22 years, fly ash amended mine soil had higher soil $\mathrm{pH}$ than untreated mine soil. In addition, the fly ash treated soils had thicker A horizons and more prolific plant roots. It was assumed that the fly ash amendment would correct the soil's physical and chemical shortcomings and improve the site's capacity to sequester carbon.

As described in Chapter 2 on the Phase I portion of the project, soil cores were collected by laying out two random transects within the proposed project area. Five samples per hectare were collected with a hollow stem soil sampler. The soil cores were placed in separate Zip-lock baggies and placed in a cooler on ice. Approximately 60 samples were collected in this manner throughout the proposed project area.

Upon return to the laboratory, the soil samples were analyzed for neutralization potential as well as soil pH. Neutralization potential is a measure of the soil's ability to neutralize acid. It is measured by adding hydrochloric acid and heating to near boiling. The $\mathrm{pH}$ is checked and more acid is added if the $\mathrm{pH}$ is greater than 4 . Hydrogen peroxide is also added to ensure complete oxidation of iron and manganese ions. The soil solution is then titrated to a $\mathrm{pH}$ of 8.2 with sodium hydroxide. Soil $\mathrm{pH}$ was determined by placing the air-dried soil in either water or a calcium chloride solution and measuring the $\mathrm{pH}$ using a $\mathrm{pH}$ meter.

The collected soil samples had an average $\mathrm{pH}$ of 4.3, which is indicative of an acidic soil typical of surface mine spoil overlying the Freeport coal seam. The neutralization potential of the soil is indicative of the amount of neutralizers present in the soil. The average value of these samples was -1.5 , indicating the absence of alkaline material.

Albright Power Station fly ash has a lime content of $~ 1.5 \%$ or $15 \mathrm{~T} / 1000 \mathrm{~T}$. Table 3-9 shows the calculation used to determine the amount of fly ash needed for soil neutralization. Based on the lime content of the Albright Power Station fly ash and the acidity of the project site, a fly ash application rate of approximately 300 tons/acre or 7,500 tons total over 25 acres was decided upon. 
Table 3-9

Calculation Used to Determine Fly Ash Necessary for Soil Amendment

\begin{tabular}{|c|c|c|c|}
\hline & $\begin{array}{c}\text { analytical results: Mg of NP / Ha } .1524 \mathrm{~m}= \\
\mathrm{Mg} / 907.4 \mathrm{Mg}\end{array}$ & $\begin{array}{c}\text { Mg NP deficit in } 12 \\
\text { Ha of soil }\end{array}$ & $\begin{array}{c}\text { ash needed to neutralize } 12 \\
\text { Ha of soil }\end{array}$ \\
\hline $\begin{array}{l}\text { Clark Farm Soil } \\
\text { Albright Units } 1 \text { and } 3 \text { ash average }\end{array}$ & $\begin{array}{r}-1.24 \\
4.29\end{array}$ & -14.88 & $8,320 \mathrm{Mg}$ \\
\hline
\end{tabular}

The plan was to divide the 30 -acre site randomly into six, five-acre plots. Five of those plots were to receive ash amendment and one plot was to serve as the control. All plots were to be cleared and tilled and/or ripped regardless of ash amendment. Fly ash from the Albright Power Station was going to be supplied by Allegheny Energy. The plan was that the fly ash would be trucked 17.5 miles from the plant and dumped along the eastern edge of the site. The fly ash would then be tilled or ripped into the top $30 \mathrm{~cm}$ of the soil surface. Only one level of ash amendment was to be used and it was to be based on the lime requirement of the soil.

\section{Clearing and Reforesting the Project Site}

\section{Clearing the Site}

The initial contractor bid for clearing and grubbing, constructing the ash haul road and spreading and tilling the ash into the project site soil was well above the allotted project budget. In addition, the cost for constructing the passive AMD treatment system necessitated limiting the contractor award until sufficient funds became available in Phase III of the project. The decision was made by the project team, including DOE, to reduce the proposed reforestation project area from 12 hectares to approximately 10 hectares, with eight hectares being amended with class $\mathrm{F}$ fly ash and the remaining two hectares un-amended as a control plot.

Site preparation for the tree-planting began in October, 2004, concurrent with the construction of the access road. The first step was clearing the site of existing vegetation as described above. The goal was to complete as many of these tasks as possible prior to the onset of wet weather. Test plot preparation was planned to terminate in the event the ground became too wet to support the ash haul trucks with startup as early in the spring as possible. The onset of wet weather then heavy snows in late 2004 eventually stopped site preparation activities. The progress that was made on clearing the project site is shown in Figure 3-16. 


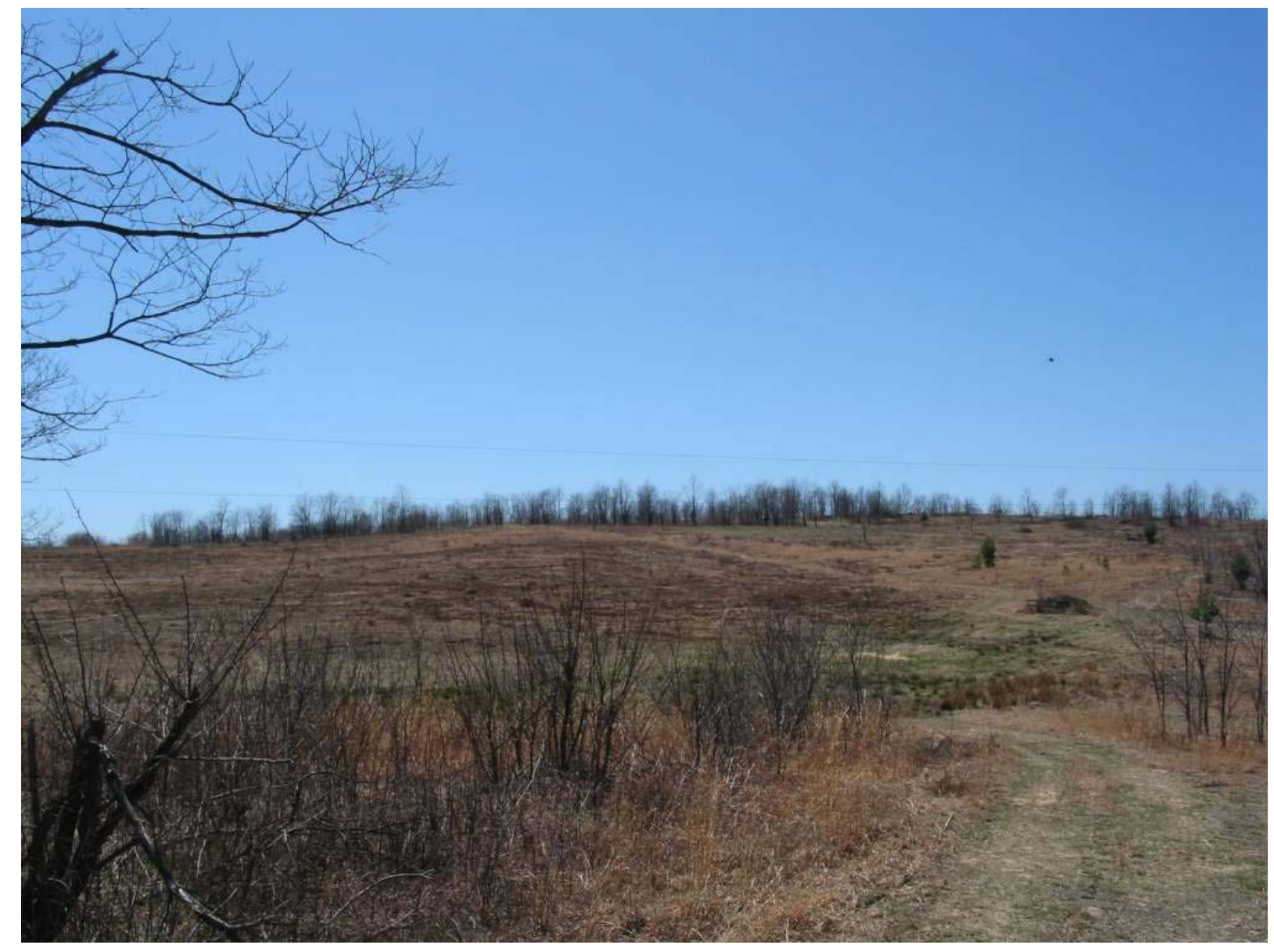

Figure 3-16

Partially Cleared Reforestation Site

\section{Reforesting the Site}

Following ash application, tree seedlings of five tree species: black cherry (Prunus serotina Ehrh.), white pine ( Pinus strobus), red oak (Quercus borealis), white oak (Quercus alba), and tulip poplar (Liriodendron tulipfera) were to be transplanted on the site. Spacing for each seedling was to be 6 x 6 feet. Single species rows within each 5 acre plot were to be randomized. Planting in rows would facilitate planting and later assessment. Based on the $6 \times 6$ foot spacing stocking, density would be approximately 1225 trees/ac, or 36,750 trees. The experimental design was to be a completely randomized design in three replications with two soil treatments: ash amendment and no ash amendment.

The previous two winters provided unusually favorable construction conditions, but the winter of 2004-2005 was snowy. The adverse weather and saturated soil conditions delayed haul road construction and site clearing, which also delayed the planting of the seedlings. It is not recommended to plant tree seedlings in northern West Virginia after mid-May because of poor survivorship potential. Anticipating the completion of construction, ash road construction, ash 
haulage and site preparation to last until early summer, the project team recommended to the DOE project manager to postpone tree seedling planting until spring 2006.

It was anticipated that the soil would be drier and more stable during late summer and early fall requiring less stone for the fly ash haul road construction, thereby reducing project costs. Moreover, it was anticipated that at that time, due to improved soil conditions, the ash haul trucks would be able to directly spread fly ash on the site by tailgating the product, further reducing costs. The situation was further complicated by the fact that Allegheny Energy's Albright power plant was at that time being operated in a limited dispatch mode. Therefore, there was insufficient ash being produced for loading and hauling directly from the plant to the project site. The alternative for supplying the necessary ash was to load and haul it from the plant's storage facility at an estimated additional cost of $\$ 10,000$. Lastly, the project team believed that tree seedling survival would be significantly greater in a spring versus a fall planting.

A request for bids for supplying and planting the seedlings was prepared and sent to qualified contractors (Appendix D). Only one quote was received for both supplying and planting the seedlings (Appendix E).

A project review meeting was held May 11, 2005 at DOE’s National Energy Technology Laboratory in Pittsburgh, Pa to resolve concerns with project delays, reporting, AMD treatment system performance, budget and future project direction. Prior to this meeting the contractor responsible for preparing the reforestation site for seedling planting was notified to cease work (Appendix F). The meeting resulted in an agreement to alter the project scope by terminating the reforestation portion of the project and developing a user-friendly computer-based screening model for evaluating the efficacy of developing multiple environmental market credits on surface mined lands. The purchase order with the contractor for construction of the ash haul road, site clearing and grubbing and ash spreading was terminated. In addition, a notice was provided to the WVDEP requesting termination of the NPDES storm water permit for reforestation site construction activities (Appendix G.)

\section{Performance of Hardwood Seedlings}

Although the reforestation did not take place, the scope of work called for measuring tree survival and growth approximately six months after planting. The performance of the seedlings was to be measured by percent survival, seedling height and diameter. In addition, an analysis of variance was to be conducted which would test individual tree species' performance on the two soil treatments. Grasses and legume growth were to be controlled either by tilling or by spraying to eliminate interference with tree growth, particularly on the non-ash treated plots.

\section{Measure Carbon Soil and Vegetative Matter Content}

If the reforestation had been completed, initial increase in carbon soil and vegetative matter content was to be measured by randomly collecting soil cores and tree stems from the five tree species in the ash treatment and control plots six months following planting. Carbon content was 
to be measured by the Wakley Blake method for soils and CHN analyzer for vegetation and compared to baseline soil content measured in Phase I.

\section{Task 3: Quantify Water Quality and Carbon Sequestration Credits}

Collecting water samples to quantify water quality was undertaken several times after the AMD passive treatment system was completed. The results are described below. Because the reforestation was terminated when the scope of the project was revised, the quantifying of carbon sequestration credits did not take place.

\section{Performance of the AMD Passive Treatment System}

The first sample for evaluating the AMD passive treatment system performance was collected approximately a month after completion. The data indicated that the treatment system was providing excellent treatment of the AMD by significantly reducing acidity, increasing alkalinity and significantly reducing iron and aluminum compared to pre-construction data (Table 3-10). Table 3-10 also shows the calculated removal efficiency and pollutant load reductions resulting from the passive AMD treatment system. These performance results were calculated from an average of seven AMD seep samples averaged within quarters. The samples were collected prior to construction and constitute the baseline condition for judging system performance. The data show that the removal efficiencies for acidity, iron and aluminum exceeded ninety-five percent. Loadings (tons/yr) for these same constituents were reduced by several orders of magnitude. Manganese is much more difficult to remove with passive treatment technology used at this site, but nevertheless receives treatment within the system.

Table 3-10

\section{Calculated Loading Reductions Resulting from Treatment (t/yr)}

\begin{tabular}{|c|c|c|c|c|c|c|c|c|c|}
\hline Sampling & units & \multicolumn{5}{|c|}{ Pre-Construction Averages } & Post- & o Poduction & Amount \\
\hline quarter/date & & 1st quarter & 2nd quarter & 3rd quarter & 4th quarter & Average & $10 / 27 / 2005$ & & kg/year \\
\hline Flow & gpm & 9.70 & 12.04 & 1.80 & 0.75 & 6.07 & 1.97 & & \\
\hline Flow & $\mathrm{m}^{3} / \mathrm{s}$ & 0.0006 & 0.0008 & 0.0001 & 0.0000 & 0.0004 & 0.0001 & & \\
\hline Field $\mathrm{pH}$ & & 2.85 & 3.25 & 3.15 & 3.00 & 3.06 & 5.5 & & \\
\hline $\mathrm{pH}$ & & 3.55 & 3.20 & 3.05 & 2.90 & 3.18 & 5.3 & & \\
\hline acidity & $\mathrm{mg} / \mathrm{L}$ & 136.50 & 127.50 & 244.50 & 319.00 & 206.88 & 0 & & \\
\hline est. acidity & $\mathrm{mg} / \mathrm{L}$ & 164.98 & 145.27 & 388.40 & 301.79 & 250.11 & 11.90 & 95 & \\
\hline alkalinity & $\mathrm{mg} / \mathrm{L}$ & 0.00 & 0.00 & 0.00 & 0.00 & 0.00 & 104 & & \\
\hline acid-alk & $\mathrm{mg} / \mathrm{L}$ & 136.50 & 127.50 & 244.50 & 319.00 & 206.88 & -92.10 & & \\
\hline $\mathrm{Mg}$ & $\mathrm{mg} / \mathrm{L}$ & 24.25 & 24.00 & 44.10 & 81.20 & 43.39 & 25 & & \\
\hline $\mathrm{Ca}$ & $\mathrm{mg} / \mathrm{L}$ & 29.35 & 31.85 & 62.90 & 80.60 & 51.18 & 108 & & \\
\hline $\mathrm{Fe}$ & $\mathrm{mg} / \mathrm{L}$ & 20.05 & 11.39 & 18.89 & 25.80 & 19.03 & 0.79 & 96 & \\
\hline $\mathrm{Al}$ & $\mathrm{mg} / \mathrm{L}$ & 10.65 & 9.93 & 45.03 & 19.40 & 21.25 & 0.42 & 98 & \\
\hline $\mathrm{Mn}$ & $\mathrm{mg} / \mathrm{L}$ & 7.62 & 8.25 & 12.97 & 25.30 & 13.53 & 6.6 & 51 & \\
\hline $\mathrm{SO} 4$ & $\mathrm{mg} / \mathrm{L}$ & 292.00 & 334.00 & 668.50 & 735.00 & 507.38 & 400 & & \\
\hline Cond & $\mu \mathrm{S} / \mathrm{cm}$ & 619.00 & 970.00 & 1609.00 & 2080.00 & 1319.50 & 713 & & \\
\hline \multicolumn{7}{|c|}{ PRE-CONSTRUCTION LOADINGS } & $\mathrm{PCL}^{*}$ & & \\
\hline acid load & $\mathrm{kg} / \mathrm{yr}$ & 3194.05 & 3490.94 & 1395.34 & 451.74 & 3031.29 & 46.78 & 98 & 2984.51 \\
\hline Fe Load & $\mathrm{kg} / \mathrm{yr}$ & 388.16 & 273.58 & 67.86 & 38.62 & 230.65 & 3.11 & 99 & 227.55 \\
\hline Al Load & $\mathrm{kg} / \mathrm{yr}$ & 206.18 & 238.50 & 161.75 & 29.04 & 257.54 & 1.65 & 99 & 255.89 \\
\hline Mn Load & $\mathrm{kg} / \mathrm{yr}$ & 147.52 & 198.13 & 46.58 & 37.87 & 164.01 & 25.95 & 84 & 138.06 \\
\hline
\end{tabular}


Table 3-11 presents data collected pre- and post-construction of the passive treatment system. The performance evaluation (i.e., reductions) is based on a comparison between an average of discharge concentrations and loadings (post-construction) to the average baseline (preconstruction) quality.

This data indicates the system removal efficiency is $75 \%$ for acidity, $86 \%$ for iron, $65 \%$ for aluminum and $57 \%$ for manganese. Pollutant loading reductions are $71 \%$ for acidity, $84 \%$ for iron, $58 \%$ for aluminum, and $50 \%$ manganese. These reductions, although respectable are somewhat lower than the initial quarter performance. A preliminary investigation of the system indicated that there might be short circuiting around the Alkaline Recharge Trench.

Table 3-11

Passive Treatment System Monitoring Results-Pre- and Post-Construction

\begin{tabular}{|c|c|c|c|c|c|c|c|c|c|c|c|c|c|}
\hline Sampling & units & \multicolumn{5}{|c|}{ Pre-Construction Averages } & \multicolumn{5}{|c|}{ Post-Construction Values } & \multirow{2}{*}{$\begin{array}{c}\% \\
\text { Reduction } \\
\end{array}$} & \multirow{2}{*}{$\begin{array}{c}\text { Amount } \\
\text { Reduced } \\
\text { kg/year }\end{array}$} \\
\hline quarter/date & & 1st quarter & 2ndquarter & 3rd quarter & 4th quarter & Average & $10 / 27 / 2005$ & $1 / 31 / 2005$ & $2 / 24 / 2005$ & 3/29/2005 & Average & & \\
\hline How & gpm & 9.70 & 1204 & 1.80 & 0.75 & 6.07 & 1.97 & 4 & 3.18 & 19.34 & 7.12 & & \\
\hline How & $\mathrm{m}^{3} / \mathrm{s}$ & 0.0006 & 0.0008 & 0.0001 & 0.0000 & 0.0004 & 0.0001 & 0.0003 & 0.0002 & 0.0012 & 0.00 & & \\
\hline Field pH & & 285 & 3.25 & 3.15 & 3.00 & 3.06 & 5.5 & 3.9 & 4.39 & 5.22 & 4.75 & & \\
\hline $\mathrm{pH}$ & & 3.55 & 3.20 & 3.05 & 290 & 3.18 & 5.3 & 3.7 & 4.6 & 4.6 & 4.55 & & \\
\hline acidity & $\mathrm{mg} / \mathrm{L}$ & 136.50 & 127.50 & 244.50 & 319.00 & 206.88 & 0 & 171 & 68 & 38 & 69.25 & & \\
\hline est. acidity & $\mathrm{mg} / \mathrm{L}$ & 164.98 & 145.27 & 388.40 & 301.79 & 250.11 & 11.90 & 141.24 & 8259 & 9.41 & 61.28 & 75 & \\
\hline alkalinity & $\mathrm{mg} / \mathrm{L}$ & 0.00 & 0.00 & 0.00 & 0.00 & 0.00 & 104 & & 2 & 0 & 26.50 & & \\
\hline acid-alk & $\mathrm{mg} / \mathrm{L}$ & 164.98 & 145.27 & 388.40 & 301.79 & 250.11 & -9210 & 141.24 & 80.59 & 9.41 & 34.78 & & \\
\hline $\mathrm{Mg}$ & $\mathrm{mg} / \mathrm{L}$ & 24.25 & 24.00 & 44.10 & 81.20 & 43.39 & 25 & 36.3 & 22 & 256 & 21.47 & & \\
\hline $\mathrm{Ca}$ & $\mathrm{mg} / \mathrm{L}$ & 29.35 & 31.85 & 6290 & 80.60 & 51.18 & 108 & 63.8 & 43 & 7.49 & 55.57 & & \\
\hline $\mathrm{Fe}$ & $\mathrm{mg} / \mathrm{L}$ & 20.05 & 11.39 & 18.89 & 25.80 & 19.03 & 0.79 & 4.14 & 4.55 & 1.03 & 263 & 86 & \\
\hline A & $\mathrm{mg} / \mathrm{L}$ & 10.65 & 9.93 & 45.03 & 19.40 & 21.25 & 0.42 & 18.9 & 10.2 & 0.56 & 7.52 & 65 & \\
\hline $\mathrm{Mh}$ & $\mathrm{mg} / \mathrm{L}$ & 7.62 & 8.25 & 1297 & 25.30 & 13.53 & 6.6 & 9.74 & 6.14 & 0.8 & 5.82 & 57 & \\
\hline $\mathrm{SO} 4$ & $\mathrm{mgl}$ & 29200 & 334.00 & 668.50 & 735.00 & 507.38 & 400 & 611 & 300 & 48 & 339.75 & & \\
\hline Cond & $\mu$ S/am & 550.00 & 725.00 & 1233.50 & 2080.00 & 1147.13 & 713 & 884 & 491 & 112 & 550.00 & & \\
\hline \multicolumn{7}{|c|}{ PRE-CONSTRUCTIONLOADINGS } & \multicolumn{5}{|c|}{ POST-CONSTRUCTIONVALUES } & & \\
\hline acidload & $\mathrm{kg} / \mathrm{yr}$ & 3194.05 & 3490.94 & 1395.34 & 451.74 & 3031.29 & 46.78 & 1127.53 & 524.17 & 363.12 & 871.15 & 71 & 2160.14 \\
\hline FeLoad & $\mathrm{kg} / \mathrm{gr}$ & 388.16 & 273.58 & 67.86 & 38.6 & 230.65 & 3.11 & 33.05 & 28.88 & 39.76 & 37.35 & 84 & 193.30 \\
\hline A Load & $\mathrm{kg} / \mathrm{gr}$ & 206.18 & 238.50 & 161.75 & 29.04 & 257.54 & 1.65 & 150.89 & 64.74 & 21.6 & 106.90 & 58 & 150.64 \\
\hline MhLoad & $\mathrm{kg} / \mathrm{yr}$ & 147.52 & 198.13 & 46.58 & 37.87 & 164.01 & 25.95 & 77.76 & 38.97 & 30.88 & 8273 & 50 & 81.28 \\
\hline
\end{tabular}

Table 3-12 contains the passive treatment monitoring results for April, May and June of 2005. The performance monitoring data presented in Table 3-12 were collected from the treatment system discharge. The performance evaluation is based on a comparison between an average of the current quarter discharge concentrations and loadings (two samples) to the average baseline (pre-construction) quality (seven samples). Comparison to baseline conditions is used because the system intercepts subsurface/subaerial flow and therefore it is impossible to collect a representative sample and flow upstream of the treatment system. 
Table 3-12

Passive Treatment System Monitoring Results: April-June, 2005

\begin{tabular}{|c|c|c|c|c|c|c|c|c|}
\hline \multirow{2}{*}{\begin{tabular}{|c|}
$\begin{array}{l}\text { Project Site } \\
\text { Sample ID } \\
\text { date }\end{array}$ \\
\end{tabular}} & \multicolumn{8}{|c|}{ Connor Run } \\
\hline & Units & $\begin{array}{c}\text { Pre Const. } \\
\text { Ave. Baseline }\end{array}$ & $\begin{array}{l}\text { System Out } \\
4 / 28 / 2005\end{array}$ & $\begin{array}{c}\text { System Out } \\
5 / 25 / 2005\end{array}$ & $\begin{array}{l}\text { System Out } \\
6 / 29 / 2005\end{array}$ & $\begin{array}{l}\text { Post Const. } \\
\text { Average }\end{array}$ & $\begin{array}{c}\% \\
\text { Reduction }\end{array}$ & $\begin{array}{c}\text { Amount Red. } \\
\mathrm{kg} / \mathrm{yr}\end{array}$ \\
\hline & $\overline{\text { GPM }}$ & 6.07 & 5.84 & 9.44 & Dry & 7.64 & & \\
\hline Flow & L/Min & 22.97 & 22.10 & 35.73 & & 28.92 & & \\
\hline $\mathrm{FpH}$ & & 3.06 & 4.75 & 7.1 & & 5.93 & & \\
\hline Lab pH & & 3.18 & 4.4 & 6.5 & & 5.45 & & \\
\hline acidity & $\mathrm{mg} / \mathrm{L}$ & 206.88 & 74 & 0 & & 37.00 & & \\
\hline est acidity & $\mathrm{mg} / \mathrm{L}$ & 250.11 & 72.51 & 9.11 & & 39.99 & 84.01 & \\
\hline alkalinity & $\mathrm{mg} / \mathrm{L}$ & 0.00 & & 25 & & 12.50 & & \\
\hline acid-alk & $\mathrm{mg} / \mathrm{L}$ & 250.11 & 72.51 & -15.89 & & 27.49 & & \\
\hline $\mathrm{Mg}$ & $\mathrm{mg} / \mathrm{L}$ & 43.39 & 25.4 & 14.8 & & 20.10 & & \\
\hline $\mathrm{Ca}$ & $\mathrm{mg} / \mathrm{L}$ & 51.18 & 52.6 & 35.2 & & 43.90 & & \\
\hline $\mathrm{Fe}$ & $\mathrm{mg} / \mathrm{L}$ & 19.03 & 1.08 & 0.41 & & 0.75 & 96.09 & \\
\hline $\mathrm{Al}$ & $\mathrm{mg} / \mathrm{L}$ & 21.25 & 9.91 & 0.07 & & 4.99 & 76.52 & \\
\hline $\mathrm{Mn}$ & $\mathrm{mg} / \mathrm{L}$ & 13.53 & 6.88 & 4.18 & & 5.53 & 59.13 & \\
\hline $\mathrm{SO} 4$ & $\mathrm{mg} / \mathrm{L}$ & 507.38 & 370 & 203 & & 286.50 & & \\
\hline cond & $\mu \mathrm{S} / \mathrm{cm}$ & 1147.13 & 635 & 485 & & 560.00 & & \\
\hline acid load & $\mathrm{kg} / \mathrm{yr}$ & 3031.29 & 845.31 & 171.77 & & 609.84 & 79.88 & 2421.45 \\
\hline Fe Load & $\mathrm{kg} / \mathrm{yr}$ & 230.65 & 12.59 & 7.73 & & 11.36 & 95.07 & 219.29 \\
\hline Al Load & $\mathrm{kg} / \mathrm{yr}$ & 257.54 & 115.53 & 1.32 & & 76.11 & 70.45 & 181.43 \\
\hline Mn Load & $\mathrm{kg} / \mathrm{yr}$ & 164.01 & 80.21 & 78.77 & & 84.34 & 48.58 & 79.67 \\
\hline
\end{tabular}

These data indicate the system achieves a removal efficiency of $94 \%$ for acidity, $96 \%$ for iron, $75 \%$ for aluminum and 59\% for manganese. Pollutant loading reductions are $80 \%$ for acidity, 95\% for iron, $70 \%$ for aluminum, and $49 \%$ manganese. These reductions improved somewhat over the previous quarter because the short-circuiting caused by sediment buildup around the Alkaline Recharge Trench (ART) was corrected during January 2005.

Passive AMD treatment system performance monitoring results for July-September, 2005 are shown in Table 3-13. All performance monitoring data were collected from the treatment system discharge. The performance evaluation is based on a comparison between an average of discharge concentrations and loadings (two samples) to the average baseline (pre-construction) quality (seven samples). Comparison to baseline conditions is used because the system intercepts subsurface/subaerial flow and therefore it is impossible to collect a representative sample and flow upstream of the treatment system.

This set of monitoring data indicates a system removal efficiency of $97.5 \%$ for acidity, 97.4\% for iron, $99.8 \%$ for aluminum and $81.6 \%$ for manganese. Pollutant loading reductions exceed $99 \%$ for acidity, iron and aluminum and $94.8 \%$ for manganese. These data indicate outstanding pollutant removal efficiency. 
Table 3-13

Passive Treatment System Monitoring Results for July-September, 2005

\begin{tabular}{|c|c|c|c|c|c|c|c|c|}
\hline \multirow{2}{*}{$\begin{array}{c}\text { Project Site } \\
\text { Sample ID } \\
\text { date }\end{array}$} & \multicolumn{8}{|c|}{ Connor Run } \\
\hline & Units & $\begin{array}{c}\text { Pre Const. } \\
\text { Ave. Baseline }\end{array}$ & $\begin{array}{l}\text { System Out } \\
7 / 28 / 2005\end{array}$ & $\begin{array}{c}\text { System Out } \\
8 / 24 / 2005\end{array}$ & $\begin{array}{c}\text { System Out } \\
9 / 14 / 2005\end{array}$ & $\begin{array}{c}\text { Post Const. } \\
\text { Average }\end{array}$ & $\begin{array}{c}\% \\
\text { Reduction }\end{array}$ & $\begin{array}{c}\text { Amount Red. } \\
\mathrm{kg} / \mathrm{yr}\end{array}$ \\
\hline Flow & $\overline{\text { GPM }}$ & 6.07 & 3.14 & 0.25 & Dry & 1.70 & & \\
\hline Flow & L/Min & 22.97 & 11.88 & 0.95 & & 6.42 & & \\
\hline $\mathrm{FpH}$ & & 3.06 & 6.05 & 5.66 & & 5.86 & & \\
\hline Lab pH & & 3.18 & 6.2 & 6.4 & & 6.3 & & \\
\hline acidity & $\mathrm{mg} / \mathrm{L}$ & 206.88 & 19 & 11 & & 15 & & \\
\hline est acidity & $\mathrm{mg} / \mathrm{L}$ & 250.11 & 6.74 & 5.58 & & 6.16 & 97.54 & \\
\hline alkalinity & $\mathrm{mg} / \mathrm{L}$ & 0.00 & 14 & 14 & & 14 & & \\
\hline acid-alk & $\mathrm{mg} / \mathrm{L}$ & 250.11 & -7.26 & -8.42 & & -7.84 & & \\
\hline $\mathrm{Mg}$ & $\mathrm{mg} / \mathrm{L}$ & 43.39 & 14 & 8.69 & & 11.35 & & \\
\hline $\mathrm{Ca}$ & $\mathrm{mg} / \mathrm{L}$ & 51.18 & 59.8 & 40.5 & & 50.15 & & \\
\hline $\mathrm{Fe}$ & $\mathrm{mg} / \mathrm{L}$ & 19.03 & 0.28 & 0.7 & & 0.49 & 97.43 & \\
\hline Al & $\mathrm{mg} / \mathrm{L}$ & 21.25 & 0.05 & 0.05 & & 0.05 & 99.76 & \\
\hline $\mathrm{Mn}$ & $\mathrm{mg} / \mathrm{L}$ & 13.53 & 3.12 & 1.87 & & 2.495 & 81.56 & \\
\hline $\mathrm{SO} 4$ & $\mathrm{mg} / \mathrm{L}$ & 507.38 & 185 & 131 & & 158 & & \\
\hline cond & $\mu S / \mathrm{cm}$ & 1147.13 & 397 & 260 & & 328.5 & & \\
\hline acid load & $\mathrm{kg} / \mathrm{yr}$ & 3031.29 & 42.25 & 2.79 & & 20.85 & 99.31 & 3010.44 \\
\hline Fe Load & $\mathrm{kg} / \mathrm{yr}$ & 230.65 & 1.76 & 0.35 & & 1.66 & 99.28 & 228.99 \\
\hline Al Load & $\mathrm{kg} / \mathrm{yr}$ & 257.54 & 0.31 & 0.02 & & 0.17 & 99.93 & 257.37 \\
\hline Mn Load & $\mathrm{kg} / \mathrm{yr}$ & 164.01 & 19.56 & 0.93 & & 8.44 & 94.85 & 155.57 \\
\hline
\end{tabular}

Monitoring results for the passive treatment system for October-December, 2005 are shown in Table 3-14. Treatment system performance declined slightly this quarter. The treatment system pollutant removal efficiency was $84.7 \%$ for acidity, $89.1 \%$ for iron, $79.6 \%$ for aluminum and $69.4 \%$ for manganese. Pollutant loading reductions were $81.9 \%$ for acidity, $87.1 \%$ for iron, $75.8 \%$ for aluminum, and $63.6 \%$ for manganese. The decline in system treatment performance as compared to the previous quarter is likely related to higher flow volumes and the decreased residence time within the system. Performance may also have been affected by lower ambient temperatures slowing microbial activity. Nevertheless, the performance of the passive AMD treatment system continues to be consistent with systems of similar size and design.

Table 3-14

Passive Treatment System Monitoring Results-October-December, 2005

\begin{tabular}{|c|c|c|c|c|c|c|c|c|c|}
\hline \multirow{2}{*}{$\begin{array}{c}\text { Project Site } \\
\text { Sample ID } \\
\text { date }\end{array}$} & \multicolumn{9}{|c|}{ Connor Run } \\
\hline & Units & $\begin{array}{c}\text { Pre Const. } \\
\text { Ave. Baseline }\end{array}$ & $\begin{array}{l}\text { System Out } \\
10 / 27 / 2005\end{array}$ & $\begin{array}{l}\text { System Out } \\
11 / 11 / 2005\end{array}$ & $\begin{array}{c}\text { System Out } \\
12 / 12 / 2005\end{array}$ & $\begin{array}{l}\text { System Out } \\
12 / 30 / 2005\end{array}$ & $\begin{array}{c}\text { Post Const. } \\
\text { Average }\end{array}$ & $\begin{array}{c}\% \\
\text { Reduction }\end{array}$ & $\begin{array}{c}\text { Amount Red. } \\
\mathrm{kg} / \mathrm{yr}\end{array}$ \\
\hline Flow & GPM & 6.07 & 1.97 & 1.54 & 12.66 & 12.66 & 7.21 & & \\
\hline Flow & L/Min & 22.97 & 7.46 & 5.83 & 47.92 & 47.92 & 27.28 & & \\
\hline $\mathrm{F} \mathrm{pH}$ & & 3.06 & 5.50 & & 3.32 & 4.50 & 4.44 & & \\
\hline Lab pH & & 3.18 & 5.30 & 4.94 & 4.13 & 4.43 & 4.70 & & \\
\hline acidity & $\mathrm{mg} / \mathrm{L}$ & 206.88 & 0.00 & 98.06 & 173.53 & 80.28 & 87.97 & & \\
\hline est acidity & $\mathrm{mg} / \mathrm{L}$ & 250.11 & 16.72 & 20.51 & 89.23 & 28.75 & 38.20 & 84.73 & \\
\hline alkalinity & $\mathrm{mg} / \mathrm{L}$ & 0.00 & 104.00 & 3.03 & 0.00 & 0.00 & 26.76 & & \\
\hline acid-alk & $\mathrm{mg} / \mathrm{L}$ & 250.11 & -87.28 & 17.48 & 89.23 & 28.75 & 11.44 & & \\
\hline $\mathrm{Mg}$ & $\mathrm{mg} / \mathrm{L}$ & 43.39 & 25.00 & 8.62 & 22.65 & 6.56 & 15.71 & & \\
\hline $\mathrm{Ca}$ & $\mathrm{mg} / \mathrm{L}$ & 51.18 & 108.00 & 27.28 & 41.62 & 15.78 & 48.17 & & \\
\hline $\mathrm{Fe}$ & $\mathrm{mg} / \mathrm{L}$ & 19.03 & 0.79 & 0.96 & 2.87 & 3.64 & 2.07 & 89.15 & \\
\hline $\mathrm{Al}$ & $\mathrm{mg} / \mathrm{L}$ & 21.25 & 0.42 & 2.35 & 12.17 & 2.41 & 4.34 & 79.59 & \\
\hline $\mathrm{Mn}$ & $\mathrm{mg} / \mathrm{L}$ & 13.53 & 6.60 & 2.36 & 5.58 & 2.04 & 4.15 & 69.36 & \\
\hline $\mathrm{SO} 4$ & $\mathrm{mg} / \mathrm{L}$ & 507.38 & 400.00 & 102.00 & 247.00 & 64.20 & 203.30 & & \\
\hline cond & $\mu \mathrm{S} / \mathrm{cm}$ & 1147.13 & 713.00 & 279.00 & 1468.00 & 600.00 & 765.00 & & \\
\hline acid load & $\mathrm{kg} / \mathrm{yr}$ & 3031.29 & 65.76 & 63.06 & 2255.06 & 726.49 & 549.66 & 81.87 & 2481.63 \\
\hline Fe Load & $\mathrm{kg} / \mathrm{yr}$ & 230.65 & 3.11 & 2.95 & 72.53 & 91.99 & 29.71 & 87.12 & 200.94 \\
\hline Al Load & $\mathrm{kg} / \mathrm{yr}$ & 257.54 & 1.65 & 7.22 & 307.57 & 60.91 & 62.41 & 75.77 & 195.13 \\
\hline Mn Load & $\mathrm{kg} / \mathrm{yr}$ & 164.01 & 51.91 & 14.51 & 282.05 & 103.11 & 59.64 & 63.64 & 104.37 \\
\hline
\end{tabular}


The passive AMD treatment system performance monitoring results for January-March, 2006 are shown in Table 3-15. These were the last set of Phase II data on the treatment system. The performance evaluation is based on a comparison between an average of discharge concentrations and loadings (seven samples) to the average baseline (pre-construction) quality (seven samples).

Table 3-15

Passive Treatment System Monitoring Results for January-March, 2006

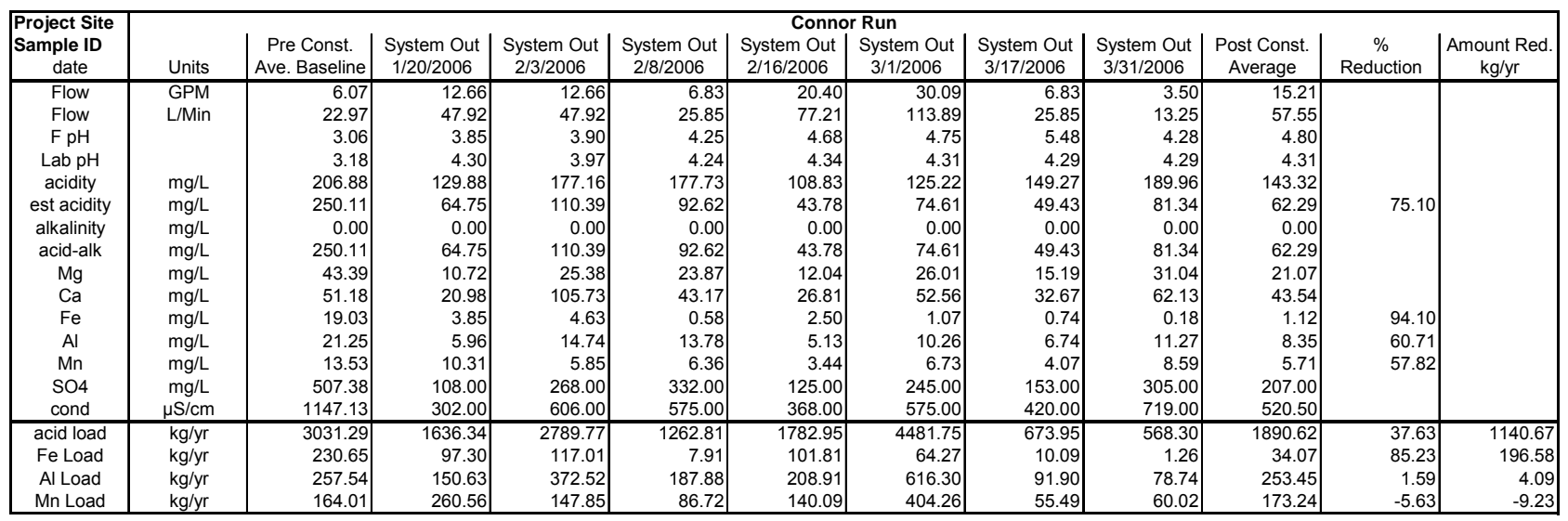

The performance of the passive AMD treatment system declined somewhat coincident with increased precipitation and an increase in groundwater flux. Average pollutant removal efficiencies this quarter were $75.1 \%$ for acidity, $94.1 \%$ for iron, $60.7 \%$ for aluminum and $57.8 \%$ for manganese. Pollutant loading reductions were $37.6 \%$ for acidity, $85.23 \%$ for iron, $1.59 \%$ for aluminum, and $-5.63 \%$ for manganese. The decline in acidity, aluminum and manganese discharge concentrations and pollutant loadings as compared to previous quarterly monitoring results was caused by an increase in pollutant loading to the treatment system resulting from seasonally higher precipitation (average discharge flow exceeded baseline flow by a factor of 2.5 $\mathrm{X})$. Nonetheless, when evaluated on an annual basis the treatment system is achieving significant pollutant removal efficiencies.

The treatment system was constructed in unconsolidated spoil material. Precipitation infiltrates the spoil increasing subsurface flow and pollutant loadings throughout the treatment system, thereby reducing residence time. The intention was that monitoring over the next quarter and anticipated lower flows will determine whether this is a seasonal trend or whether it represents a longer-term decline in system performance. Since no further sampling took place, however, this determination was not able to be made.

\section{Task 4: Prepare Final Report}

This document serves as the final report for all phases of the project. 


\section{Conclusion}

The work planned for Phase II was only partially completed. The design and construction of the passive AMD treatment system, as well as the pre- and post-construction water sampling, were completed successfully. Post-construction water sampling demonstrated that the performance of the treatment system varied somewhat from sample to sample, but that overall, pollution removal efficiencies were consistent with systems of similar size and design.

The reforestation task was only partially completed due to a number of issues, among them the delay in finalizing any kind of access agreement with Mr. Clark, the weather and cost factors that delayed and ultimately terminated the construction of the access road, the harsh winter conditions that delayed the planting of the trees, and the fact that the fly ash from Allegheny Energy's Albright Power Station would not be available when needed. Ultimately the decision was made to alter the project scope by terminating the reforestation portion of the project, including the quantification of carbon content in order to gain carbon sequestration credits.

Phase II concluded when the project scope was revised in May of 2005. At that time it was agreed to prepare a new scope of work for Phase III of the project. 



\section{PHASE III}

In late 2005, the scope of work for the revised project, designated Phase III, was submitted to DOE. Phase III work was to be performed under a revised Cooperative Agreement, which was signed by the Department of Energy (DOE) on May 18, 2007 and by the Electric Power Research Institute (EPRI) on June 1, 2007. The revised Cooperative Agreement modified the research project as described below.

\section{Objective of Revised Project}

The principal objective of the revised research project is to develop a simple to follow guide for use by landowners and third party investors for evaluating the economic benefits of developing multiple environmental market credits on surface mined lands. The guide will provide users with basic background understanding of the potential for four environmental credit markets, current status of the markets, general trading rules and performance requirements, current and anticipated credit prices, potential transaction costs, and state, national and private market contact information.

The guide will include a two-step process for evaluating potential market credits on a specific mined land reclamation site. First, an individual screening level process decision trees for evaluating the general feasibility of developing $\mathrm{CO}_{2}$ and water quality trading credits, as well as conservation and/or wetland banks will be developed. Factors to be included in the decision diagrams include site size, topography, land use, location, soil characteristics, drainage quality and volume, available or potential markets (buyers, sellers and a mechanism), regulatory impediments among others. The decision trees will be useful for determining whether more detailed economic analysis, outlined below, is warranted for a particular site.

Second, a user-friendly, interactive model for evaluating costs and potential financial gains from developing water quality and carbon sequestration trading credits through reclamation (reforestation and application of passive AMD treatment technology) on mined lands will be developed. The model will be based on data and information resulting from work accomplished under Project Phases I and II, as well as that developed by the NMLRC over the past twenty years. The model will be constructed to provide for a recommended range of variable cost inputs, such as length of access road, amount of required clearing and grubbing, volume of grading, species and size of seedlings, required soil amendment, permitting, type and size of required treatment system based on water quality and flow and market transaction costs.

The model will be tested and verified against the cost of several reclamation scenarios at the thirty acre Valley Point, WV project site. Historical costs developed by the NMLRC on hundreds of reclamation projects within the region will be used. 
Estimated costs per acre and per benefit will be calculated (e.g., cost per carbon or water quality unit created). Landowners would then be able to evaluate the market price per credit necessary to warrant their investment in restoration. A range of current market prices for benefit credits will be provided to support landowners' ability to speculate on future prices.

The revised scope-of-work requires resumption of water quality sampling at the passive treatment system. Even though a R\&D access agreement is still in force with the land owner, a letter will be sent to the land owner requesting permission to enter his property. The land owner has been very vocal about his disappointment that Phase II (planting of trees for carbon sequestration) was not completed, and may not grant access. There is concern that if the University sampling crew enters the property under the R\&D access agreement only that they may be at risk. If the land owner does not grant access or does not respond to EPRI's letter requesting access for water quality sampling, EPRI will request that the water quality sampling task be deleted.

\section{Revised Scope of Work and Timeline}

The revised Cooperative Agreement had the following scope of work and timetable, which was to be performed by West Virginia University, is shown below:

\section{Task 1: Quarterly Reports}

Prepare quarterly reports in conformance with DOE requirements.

\section{Task 2: Continue Monitoring the Passive Treatment System Performance}

Continue monitoring the passive treatment system performance twice per month. Based on this data, annual load reductions will be calculated for acidity, iron, aluminum and manganese.

\section{Task 3: Literature Search to Establish the Status of Environmental Credit Markets}

Evaluate the scientific, grey and trade press literature to establish the status of both international and national carbon trading markets and national water quality trading, conservation banking and wetland mitigation banking markets. The search will focus on identifying and synopsizing the viability and location of existing markets, respective credit prices, available transaction costs, institutional arrangements and contacts for additional information. To the extent it exists, ongoing environmental credit development on mined lands by either public or private entities will also be identified and described.

\section{Task 4: Develop Decision Trees}

This task will develop general screening level decision process diagrams that will allow the user to determine the preliminary feasibility of developing environmental market credits on a particular mined land site. Because of varying site conditions and market requirements a 
separate decision diagram will be developed for carbon trading, water quality trading, conservation banking and wetland mitigation banking. The major factors that must to be considered for advancing a project will be identified and incorporated. For example, development of all environmental credits requires an existing market with willing buyers and sellers and appropriate institutional arrangements, as well as landowner cooperation. However, for development of carbon sequestration credits by reforestation of a mined site, the most important factors would include size, soil composition, topography, site accessibility, need for and availability of soil amendment, and existing vegetation. Whereas, for development of water quality trading credits primary factors to consider would include the volume and quality of drainage, accessibility, adequate area, and topography.

\section{Task 5: Develop Spreadsheet Model}

Visual Basic software will be used for development of a user-friendly spread sheet model that can be used by developers in an interactive fashion to evaluate the costs of developing carbon and water quality trading credits on mined lands. Separate spreadsheets will be constructed for evaluating the costs and benefits of developing carbon and water quality trading credits. The sheets will be linked to produce total net costs and potential benefits without double counting costs, such as access road and site preparation that could be common for development of both types of credits.

The model will provide for input of default values from a range of variable costs associated with the specified factor, such as seedling species and age class and treatment system type and size. All cost inputs will be derived from costs incurred in previous project phases, from NMLRC historical records and from AMD TREAT, developed by the Office of Surface mining to estimate the cost of constructing AMD treatment systems.

Example Model Inputs for calculating costs are as follows:

- Project area

- Project location

- Soil composition

- Soil amendment type

- Soil preparation

- Seedling species and age class

- Access road length

- Clearing and grubbing

- Drainage quality and flow

- Required grading

- Type and size of Passive treatment system 


\section{Task 6: Prepare Final Report}

A final report will be prepared describing all aspects of the projects three phases including objectives, approach, material and methods and resulting environmental and economic benefits of applying a market-based approach for AML restoration. More specifically, but not limited to, the final report will discuss and evaluate site selection criteria, including the access agreement and its development with the land owner; all data collected (raw data to be included in appendices); all aspects of the effort to prepare the site for tree planting and the reasons for not completing this phase of the project; the data used to design the passive treatment system, and treatment goals; the model used to develop the design of the passive treatment system and its data requirements; the performance of the passive treatment system against the treatment goals. The final report will also include the results of tasks 2 through 5, as described above.

\section{Timeline}

\begin{tabular}{|c|c|c|c|c|c|c|c|c|c|c|c|c|c|}
\hline \multirow[t]{2}{*}{ ID } & \multirow[t]{2}{*}{ Task Name } & \multicolumn{12}{|l|}{2006} \\
\hline & & January & February & March & April & May & June & July & August & September & October & November & December \\
\hline 1 & Start & $\downarrow$ & & & & & & & & & & & \\
\hline 2 & Task 1 - Quarterly Reports & 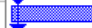 & & & & & & & & & & & \\
\hline 3 & Task 2 - Passive System Monitoring & $=$ & 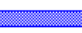 & & & & & & & & & & \\
\hline 4 & Task 3 - Literature Search & & & & & & & & & & & & \\
\hline 5 & Task 4 - Decision Trees & & & & , & & & & & & & & \\
\hline 6 & Task 5 - Develop Spreadsheet Model & & & & & & & & & & & & \\
\hline 7 & Task 6 - Final Report Preperation & & & & & & & & & & & 1 & \\
\hline 8 & End & & & & & & & & & & & & \\
\hline
\end{tabular}

\section{Phase III Cost Proposal from West Virginia University}

EPRI requested its contractor, West Virginia Research Institute, West Virginia University, to prepare a new cost proposal based on this revised scope. EPRI received the West Virginia Research Institute, West Virginia University revised cost proposal on August 15, 2007. The proposed cost was $\$ 152,689$ and was $\$ 63,536$ higher than what was submitted to DOE on $12 / 23 / 06$ for the same scope of work.

As a result of the revised cost proposal, EPRI requested that the University review and revise its cost proposal. Concomitantly, EPRI began internal discussions on how to proceed without the University, if the University's cost could not be brought in line with the budget. After several iterations, the University presented on October 17, 2007 a final cost of $\$ 139,715$. It was decided that this cost proposal was not acceptable, and that EPRI would take over the work. EPRI closed its contract with West Virginia Research Institute, West Virginia University on April 24, 2008. The University agreed to provide all data collected during the time it was under contract to EPRI. The data will be used to develop the final project report to DOE.

\section{Project Workscope Shifts from West Virginia University to EPRI}

On October 19, 2007, the EPRI project manager spoke with the DOE project manager, concerning the University's cost proposal and requested that EPRI take over the project. EPRI also requested that Task 2 be deleted from the scope of work. DOE approved EPRI's request to take over the project and the deletion of Task 2. 
In November 2007, EPRI's project manager learned that the EPRI technical lead was not able to work on the project. The EPRI project manager worked with EPRI management to assemble a new team to pursue the Phase III work.

\section{EPRI's Revised Scope of Work}

The principal objective of the revised research project was to develop a simple to follow guide for use by landowners and third party investors for evaluating the economic benefits of developing multiple environmental market credits on surface mined lands. The guide will provide users with basic background understanding of the potential for four environmental credit markets, current status of the markets, general trading rules and performance requirements, current and anticipated credit prices, potential transaction costs, and state, national and private market contact information.

The guide will include a two-step process for evaluating potential market credits on a specific mined land reclamation site. First, an individual screening level process decision trees for evaluating the general feasibility of developing $\mathrm{CO}_{2}$ and water quality trading credits, as well as conservation and/or wetland banks will be developed. Factors to be included in the decision diagrams include site size, topography, land use, location, soil characteristics, drainage quality and volume, available or potential markets (buyers, sellers and a mechanism), regulatory impediments among others. The decision trees will be useful for determining whether more detailed economic analysis, outlined below, is warranted for a particular site.

Second, a user-friendly, interactive model, EPRI’s Strategic Eco-Asset Manager Model (STREAM) for evaluating costs and potential financial gains from developing water quality and carbon sequestration trading credits through reclamation on mined lands will be used. The model will be revised to include water quality credit development. The model will be based on data and information resulting from work accomplished under Project Phases I and II, as well as other data available in peer-reviewed literature.

Estimated costs per acre and per benefit will be calculated (e.g., cost per carbon or water quality unit created). Landowners would then be able to evaluate the market price per credit necessary to warrant their investment in restoration. A range of current market prices for benefit credits will be provided to support landowners' ability to speculate on future prices.

\section{Final Stage of the Project}

EPRI's project manager worked with Environment Sector management and EPRI's Legal Department to have STREAM placed into the public domain, which took place in June, 2008. EPRI was to provide the model to DOE to be used by interested parties for evaluating costs and potential financial gains from developing water quality and carbon sequestration trading credits through reclamation on mined lands.

Once STREAM was placed into the public domain, the project could resume. EPRI prepared a no-cost extension of it cooperative agreement with DOE in late June, 2008. The no-cost 
extension proposed extending the agreement until December 31, 2009 so that the work could be completed. It was intended that the no cost extension would provide the costs associated with each of the tasks in the scope-of-work.

\section{Conclusion}

As a result of delays by both parties in finalizing both the revised scope of work and the no-cost extension, the project was not able to move forward in a timely fashion. After a discussion with DOE, a decision was made on November 20, 2009 to produce a report solely on the work that was performed in Phases I and II of the project. This report is that final deliverable. 


\section{SUMMARY AND CONCLUSIONS}

In summary, two main conclusions can be drawn from this project:

- The use of treatment to remediate AMD with the goal of capturing future water credits is relatively straightforward, assuming that the right property is available and the appropriate technologies are employed.

- Trying to reforest an existing site with the objective of capturing future carbon credits, however, is much more complex and challenging.

Each of these conclusions is discussed below in greater detail.

\section{Remediating Acid Mine Drainage to Capture Future Water Credits}

The success of this portion of the project was due to several factors. These included finding an appropriate site containing AMD that was degrading the water quality of receiving streams and impeding development of an aquatic habitat, securing the agreement of the landowner to remediate the site for possible future water credits, conducting extensive water quality sampling, and designing and building an effective water treatment system.

This project began just before the U.S. Environmental Protection Agency released a policy encouraging states to developing trading programs to help restore impaired waters at less cost. Since the project team was able to find an appropriate site and the landowner could clearly envision the financial incentives in future water credits, the first two necessary conditions were easily met.

Building an effective water treatment system involved conducting extensive water quality sampling to determine the best design for the system. For this project, it was decided that a passive AMD water treatment system would best meet the project's objectives. The system would neutralize acidic discharges of mine seeps entering receiving streams. The increased $\mathrm{pH}$ would also precipitate metals such as iron, aluminum and manganese, decreasing metal loading to receiving streams.

When designing and building a passive treatment system, the AMD volume and quality dictate the size, configuration and cost. In general, the greater the flow volume and the worse the water quality, the more the system will cost, and these costs will be incurred long before any water credits can be claimed. On the other hand, higher AMD volumes lead to greater treatment efficiency, ideally resulting in more water quality credits. It should be noted, however, that the costs of pre- and post- restoration monitoring to quantify and verify environmental credits can also add significant costs to the project. 
For this project, a relatively inexpensive system was designed utilizing four treatment technologies:

- Alkaline recharge trenches to collect acidic subsurface flow from the spoil.

- Open limestone channels to convey water from one treatment cell to the next.

- A limestone foundation drain to collect the springs and channel them as high into the treatment system as possible.

- Impoundments to serve as retention structures for precipitating and retaining metals.

Post-construction water quality sampling clearly demonstrated that the system's pollution removal efficiencies were consistent with systems of similar size and design.

\section{Reforesting a Site to Capture Future Carbon Credits}

The steps necessary to reforest an existing site to capture future carbon credits can be substantially more significant, as they were for this project. After identifying an appropriate site, the project team had to persuade the landowner to sign a conservation easement, conduct a land survey, obtain the necessary permits, gather soil samples to determine the amount of fly ash that would be required for soil amendment, identify a source, secure access, and arrange for transportation of the fly ash, and reforest and enhance the site. In addition, weather can have a substantial impact on project costs and schedules.

\section{Obtaining a Conservation Easement}

Of all of these steps, securing a conservation easement was the most challenging, and these challenges can serve as an example to anyone considering a similar project. A conservation easement is a legally binding deed restriction that landowners voluntarily place on their property to assure that the property will be perpetually preserved in a certain condition. Conservation easements generally restrict the landowner from subdividing or fragmenting the property. A conservation easement also commits the landowner to implementing a stewardship plan. ${ }^{8}$

In this project, the landowner's initial agreement to a conservation easement gave way to reluctance once he fully understood the full ramifications. The project was substantially delayed by a protracted series of negotiations with the landowner, and finally the only agreement that could be reached was a five-year research access agreement. Although this would have allowed for the planting of the trees, it effectively terminated the portion of the project that focused on obtaining future carbon credits. It should also be noted that in this project, Mr. Clark was not required to pay for the reclamation activities. In most cases, however, the landowner would have to incur the costs of the reclamation before any future credits could be obtained.

\section{Using Fly Ash as a Soil Amendment}

Some of the other steps, such as the land survey, obtaining permits, and gathering soil samples were fairly straightforward. Some of the issues around the fly ash for soil amendment were also 
problematic, however. Although the selected site was near a coal-burning power plant that produced fly ash as a by-product, it was necessary to build an access road on the Clark property that could support the weight of the trucks transporting the ash. The cost of the access road was substantially underestimated and its construction was significantly delayed by bad weather, which also delayed clearing the land prior to planting of the trees for reforestation. In addition, the power plant was no longer being dispatched by the time some of these delays had been addressed.

Credit developers should also be aware that a potential issue related to using coal combustion products as a soil amendment is the public concern regarding the potential release of toxic metals. Although numerous researchers (Parizek ${ }^{9}$, 1986; Daniels ${ }^{10}$, et. al 2002; Ziemkiewicz ${ }^{11}$, 2004; White ${ }^{12}$, 2004) have demonstrated that the beneficial use of CCPs for mine land reclamation is not an environmental concern, if managed properly, a public stigma remains. Moreover, many states, including West Virginia, have recognized the value of using CCPs for mine reclamation and have policies and regulations in place that guide this practice. Nevertheless, environmental credit developers must be aware of and prepared to address any public concerns that might arise as a result of utilizing CCPs in site restoration.

\section{Weather and Cost Challenges}

It is apparent that weather is a critical factor in developing cost-effective environmental credits through restoration of degraded mined lands, particularly in northern latitudes. Weather related construction delays resulting in additional construction costs can have both a direct and indirect impact on the cost of environmental credit development and should be considered in scheduling construction activity. Weather related delays significantly slowed reforestation site clearing and delayed ash haul road construction and subsequent soil amending and tree planting. Construction during wet winter conditions can increase costs in several ways: first, the volume of stone required to construct a road base of sufficient capacity to support large delivery trucks will likely be greater than would be required for summer delivery; second, soft, wet soils will prohibit delivery dump trucks from directly tailgating the amendment on the site thereby increasing the cost to distribute the material over the site. For an investor, this delay in bringing credits to market would diminish the return on investment due to the time value of money.

In order for environmental credit markets to become attractive to investors, credit development must be accomplished at a reasonable cost. It is obvious that the larger the return to investors, the greater the incentive to invest. In this project, a number of site-specific cost factors became evident that should be considered in selecting a site to restore for development of environmental credits. These include the following:

\section{Stand Conversion}

Existing vegetation can assist or interfere with tree seedling growth. Control or removal of this vegetation is generally warranted. In addition, this vegetation has some carbon sequestration potential and it represents baseline conditions against which gains in carbon sequestration potential should be measured. 


\section{Soil Chemistry and Compaction}

Trees planted in soil that has been heavily compacted and is of poor quality and composition do not survive and grow as vigorously as those planted in good soils (Burger and Zipper ${ }^{13}$, 2002). Soil chemistry and composition becomes an issue when determining the tree species to be planted. Some species, such as commercial hardwoods (oaks, black cherry and tulip poplar), do better in slightly acidic and non-compacted spoil while sycamore, red maple and green ash are more tolerant of sites that are compacted and poorly drained and are more alkaline in nature. Spoil requiring an alkaline amendment and significant ripping will result in additional costs to prepare for reforestation.

\section{Site Topography}

Reclamation sites with steep grades or that contain an un-reclaimed high wall may require extensive grading and backfilling at additional cost.

\section{Location}

Location may become a cost issue if a soil amendment is required. For example, in this project an alkaline amendment was needed to neutralize the acidic spoil in preparation for planting hardwood tree species. Class F fly ash was chosen as the amendment because the product is relatively inexpensive compared to lime and it has been widely used for mine reclamation. This choice dictated that the site be located within a reasonable trucking distance of a coal-fired power plant in order to reduce trucking costs. Additionally, the distance from a road to the reclamation site may be a cost issue if a road must be constructed to accommodate the heavy ash-haul trucks. For example, the reforestation site chosen for this project required construction of a 670-meter ash haul road at an estimated cost of $\$ 20,000$ 


\section{$\boldsymbol{A}$ \\ INITIAL ACCESS AGREEMENT}

\section{DEED OF ACCESS AND DEDICATION EASEMENT}

THIS DEED OF ACCESS and DEDICATION EASEMENT is made this day of 2004 by and between Jeffrey A. Clark and Diane M. Clark of Valley Point, Preston County , West Virginia, having the power to convey an interest in certain real estate that they acquired by deed recorded on December 29, 1997 in Deed Book 600 at Page 388 recorded among the land records of Preston County, West Virginia, (Grantor) and the Electric Power Research Institute, Inc. (EPRI) and its agents, contractors or employees, hereinafter referred to collectively as the ("Grantees"), for the terms and conditions of this Access and Dedication Easement hereinafter referred to as the "Easement".

\section{WITNESSETH:}

A. That the Grantee has been awarded a grant by the U.S. Department of Energy and the U.S. Department of Interior to demonstrate the efficacy of a market based approach for the reclamation of former mine lands in West Virginia. The project emphasis is on developing water quality and carbon trading credits by reforestation and treatment of acid mine impacted streams. The result to be achieved will include enhanced habitat for wildlife. Water quality credits will be developed through passive treatment technology and carbon credits will be developed through carbon sequestration in planted hardwood trees. Grantor owns land, which they are willing to allow the implementation of improvements as contemplated by this program.

B. That for and in consideration of the sum of one dollar one other good and valuable consideration, the receipt of which is hereby acknowledged and the improvements to be received to their property, the Grantor hereby agrees as follows:

1. Grantor dedicates and grants to the Grantees, their successors and assigns, the right, privilege, access easement and right-of-way (the "Easement"), for the use and purposes and under the terms and conditions described below in, on, under, through, along and across a certain parcel of land owned by the Grantor in Valley Point, West Virginia acquired by Grantor on December 29, 1997 in Deed Book 600 Page 388 and known as Parcel 11 in Tax Map 24 and as more specifically identified in the Site Plan prepared by Triad Engineering Incorporated dated October 22, 2003 covering the area containing 34.28 acres as specifically delineated by a metes and bounds description attached hereto as Ex. A. 
2. Grantor further grants to Grantee, its contractors, agents, employees and its successors and assigns, with General Warranty of title, a common or shared easement for the service (the "Service Easement") to the proposed improvements on the 34.28 acres identified in Exhibit A. The Service Easement shall lead from West Virginia County Route 15 known as Hudson Road and run for approximately 2,177 lineal feet as more clearly depicted on the Triad Engineering Site Plan map dated October 23, 2003. Each Easement and Service Easement shall be subject to the following terms and conditions:

3. Grantee shall have the right to design, grade, provide soil amendments, till, restore, maintain and monitor and otherwise plant the 34.28 acres with trees in an attempt to restore the acreage into a forested system resulting in the improved restoration of an abandoned mining site. The forest as it matures will help preserve wildlife and capture carbon as well as help aid in the treatment of acid impacted streams resulting from mining operations conducted on the property in the past. The purpose of this program as well as the approvals given by Grantor to Grantee is to lay the framework for development of mine land reclamation and the creation of ecological credits under certain Federal and State rules, regulations and laws either currently in force and effect or to be enacted in the future. The location and scope of all improvements shall be with the cooperation and coordination of the Grantor, however, EPRI shall have the sole right to finalize and implement the design and planting of the project so long as the final product does not conflict with other local or state requirements with regard to the land use practices in Valley Point, West Virginia.

4. The Grantee shall have the right, at any time and from time to time, to clear and keep clear, the Easement and its Service Easement of trees, shrubs, roots, undergrowth, buildings, structures, and other obstructions not consistent with the program of planting trees and grasses to maximize the absorption of carbon. The Grantees shall not be responsible for the replacement or reimbursement cost of any trees, shrubbery or landscaping material.

5. The Grantee shall have the perpetual right of ingress to and egress from the Easement and any Service Easement at any time, and from time to time, for the purpose of constructing, inspecting, maintaining and monitoring or operating its carbon mitigation project. If any Grantee is reasonably unable to exercise its right of ingress and egress over, upon or along the Easement on the Property, such Grantee shall have such right of ingress and egress over the Property adjacent to the Easement. Each Grantee shall have the further right of ingress to and egress from the Easement over such private roads as may now or hereafter exist on the Property. The right, however, is reserved to the Grantor, its successors and assigns to shift, relocate, close or abandon such private roads at any time. If there are no public or private roads reasonably convenient to the Easement, any Grantee shall have such right of ingress and egress over the Property adjacent to the Easement and lying between public or private roads and the easement in such manner as shall occasion the least practicable damage in inconvenience to the 
Grantor, its successors and assigns. Each such Grantee shall be liable for all damages resulting from its own exercise of the right of ingress and egress. Except in the event of any emergency, each Grantee will make a reasonable attempt to notify the Grantor or property owner/occupant prior to ingress upon the property for the purpose of constructing or maintaining its carbon mitigation project.

6. The carbon mitigation project and all credits accruing therein and constructed as described herein shall remain the property of the Grantee. The Grantee shall have the right to inspect, rebuild, remove, repair, improve, maintain and monitor the improvements within the easement and Service Easement and make such changes, alterations, substitutions, additions to or extensions of its project as Grantee may from time to time deem advisable. The Grantee may build an access road within the Service Easement which improvement shall not be removed.

7. Grantor, its successors and assigns, may use the surface of the ground within the Easement and any Service Easement for any purpose not inconsistent with any of the rights granted to any of the Grantees provided that (1) no buildings, structures or other obstructions may be constructed on or within the Easement or the Service Easement; (2) no excavations, fills or storage of water may be made thereon, and (3) no cutting or removal of any trees is allowed unless with the express written approval of the Grantee.

8. If Grantor, its successors and assigns, use of any Service Easement or Easement interferes with or endangers the construction, operation or maintenance of the improvements made by Grantee, the Grantee may take action to enjoin said interference and the Grantor, its successors and assigns, shall reimburse such Grantee its full cost of said action.

9. The Grantee may assign or transfer, without limitation, all or any part of the rights granted to it for the purpose of constructing, operating and maintaining the improvements within the intent of this Agreement.

10. Neither Grantor nor its successors or assigns shall make any other use of the subsurface of the land within the portion of the Easement which is reserved for the use of the Grantees or their successors or assigns pursuant to the preceding sentence without the written consent of all the Grantee.

11. By the recordation of any such deed or plat conveying any such Easement by reference to this Agreement, Grantor warrants each Easement and Service Easement generally and covenants that it is seized of and has the right to convey such Easements and Service Easements, rights and privileges; that the Grantees shall have quiet and peaceable possession, use and enjoyment of the aforesaid easements in perpetuity and that Grantor shall execute such further assurances thereof as may be required to allow Grantee to perform all work contemplated hereunder. Grantor may be required to execute in the future a Conservation 
Easement or Deed Restriction, which preserves the acreage within the boundaries of the Easement as a conservation area in perpetuity.

12. Grantee shall indemnify, protect, save harmless and insure the Grantor from and against any and all claims and demands for damages to property, and for injury or death to persons, including payments made under any Workers' Compensation Law or under any plan for employees' demands, which may arise out of or be caused by its contemplated activities under this Access and Deed of Easement. Grantee shall be fully responsible and hold harmless Grantor for all costs associated with all work contemplated under this Agreement except that the Grantor shall remain responsible for any real estate taxes it is required to pay as the owner of fee simple title of all land within the easement area.

13. The failure of any party to enforce or insist upon compliance with any of the terms or conditions of this instrument shall not constitute a general waiver or relinquishment of any such terms or conditions, but such conditions and terms shall be and remain at all times in full force and effect.

IN WITNESS WHEREOF, Grantor has caused their names to be signed this Day of January 2004.

\section{GRANTOR}

By:

Jeffrey A. Clark

State Of West Virginia
By:

Diane M. Clark

COUNTY OF , to wit:

I, the undersigned, a Notary Public in and for the County and State aforesaid, do hereby certify that Jeffrey A. Clark and Diane M. Clark whose names as are subscribed above have signed the foregoing Access and Deed of Easement, have personally acknowledged, subscribed and sworn to the same before me in my aforesaid jurisdiction.

GIVEN under my hand and seal this day of 20 My commission expires: 


\section{B}

\section{FINAL ACCESS AGREEMENT}

\section{ACCESS AGREEMENT}

THIS ACCESS AGREEMENT is made this $2^{\text {nd }}$ day of April, 2004 by and between Jeffrey A. Clark and Diane M. Clark of Valley Point, Preston County , West Virginia, BEING THE OWNERS of certain real estate that they acquired by deed recorded on December 29, 1997 in Deed Book 600 at Page 388 recorded among the land records of Preston County, West Virginia, (Grantor) and the Electric Power Research Institute, Inc. (EPRI) and its agents, contractors or employees, referred to as the ("Grantees").

\section{WITNESSETH:}

A. That the Grantees have been awarded a grant by the U.S., Department of Energy and the U.S. Department of Interior to demonstrate the efficacy of a market based approach for the reclamation of former mine lands in West Virginia. The project emphasis is on developing water quality and carbon trading credits by reforestation and treatment of acid mine impacted streams. The result to be achieved will include enhanced habitat for wildlife. Water quality credits will be developed through passive treatment technology and carbon credits will be developed through carbon sequestration in planted hardwood trees. Grantor owns land which they are willing to allow the implementation of improvements as contemplated by this program.

B. That for and in consideration of the sum of One Dollar (\$1.00) and other good and valuable consideration, the receipt of which is hereby acknowledged and the improvements to be received to their property, the Grantor hereby agrees as follows:

1. Grantor dedicates and grants to the Grantees the right to access for the use and purposes and under the terms and conditions described below in, along and across their land to a certain parcel of land owned by the Grantor in Valley Point, West Virginia acquired by Grantor on December 29, 1997 in Deed Book 600 Page 388 and known as Parcel 11 in Tax Map 24 and as more specifically identified in the Site Plan prepared by Triad Engineering Incorporated dated October 22, 2003 covering the area containing 34.28 acres as specifically delineated by a metes and bounds description attached hereto as Ex. A.

2. Grantor further grants to Grantee, its contractors and agents the ability to make the proposed improvements on the 34.28 acres identified in Exhibit A . The right of access shall lead from West Virginia County Route 15 known as Hudson Road and run for approximately 2,177 lineal feet as more clearly depicted on the Triad Engineering Site Plan map dated October 23,/2003. This Agreement will be subject to the following terms and conditions:

3. Grantee shall have the right to design, grade, provide soil amendments, till, restore, maintain and monitor and otherwise install a passive acid mine drainage treatment system in an effort to improve water quality and to plant the 34.28 acres with trees in an attempt to restore the acreage into a forested system. These efforts will result 
in the improved restoration of an abandoned mining site. The forest as it matures will help preserve wildlife and capture carbon as well as help aid in the treatment of acid impacted streams resulting from mining operations conducted on the property in the past. The purpose of this program as well as the approvals given by Grantor to Grantee is to lay the framework for development of mine land reclamation and the creation of ecological credits under certain Federal and State rules, regulations and laws either currently in force and effect or to be enacted in the future. The location and scope of all improvements shall be with the cooperation and coordination of the Grantor, however, EPRI shall have the sole right to finalize and implement the design and planting of the project so long as the final product does not conflict with other local or state requirements with regard to the land use practices in Valley Point, West Virginia.

4. The Grantee shall have the right, at any time and from time to time, to clear and keep clear the access area as well as the 34.28 acres of unwanted trees, shrubs, roots, undergrowth, buildings, structures, and other obstructions not consistent with the program of planting trees and grasses to maximize the absorption of carbon. The Grantees shall not be responsible for the replacement or reimbursement cost of any trees, shrubbery or landscaping material.

5. The Grantee shall have the right of ingress to and egress from the Property for the purpose of constructing, inspecting, maintaining and monitoring its carbon mitigation and water quality enhancement project for a period of five (5) years from the date of this Agreement. If there are no public or private roads reasonably convenient to the Property Grantee shall have such right of ingress and egress over the Property adjacent to the access area in such manner as shall occasion the least practicable damage and inconvenience to the Grantor, its successors and assigns. Each such Grantee shall be liable for all damages resulting from its own exercise of the right of ingress and egress. Except in the event of any emergency, each Grantee will make a reasonable attempt to notify the Grantor or property owner/occupant prior to ingress upon the property for the purpose of constructing or maintaining its carbon mitigation project.

6. The Grantee shall have the right to inspect, rebuild, remove, repair, improve, maintain and monitor the improvements within the Property boundaries and make such changes, alterations, substitutions, additions to or extensions of its project as Grantee may from time to time deem advisable. The Grantee may build an access road within the Property which improvement shall not be removed but shall be abandoned in favor of the Grantor as the termination of this Agreement.

7. Grantor, its successors and assigns, may use the surface of the ground of the Property for any purpose not inconsistent with any of the rights granted to any of the Grantees provided that (1) no buildings, structures or other obstructions may be constructed within the Property boundaries. Grantor shall have the rights to all trees on the Property whether planted by Grantee or not at the end of the five year term of this 
Agreement. Grantor shall comply with all State and Federal laws, rules and regulations relating to the environment as it apply to the subject Property

8. The terms of this Agreement shall be for five (5) years from the date of this Agreement and be binding on any successor or assign of Grantor during such term.

9. Grantee shall indemnify, protect, save harmless and insure the Grantor from and against any and all claims and demands for damages to Property, and for injury or death to persons, including payments made under any Workers' Compensation Law or under any plan for employees' demands, which may arise out of or be caused by its contemplated activities under this Access Agreement. Grantee shall be fully responsible and hold harmless Grantor for all costs associated with all work contemplated under this Agreement except that the Grantor shall remain responsible for any real estate taxes it is required to pay as the owner of fee simple title of all land within the easement area.

10. The failure of any party to enforce or insist upon compliance with any of the terms or conditions of this instrument shall not constitute a general waiver or relinquishment of any such terms or conditions, but such conditions and terms shall be and remain at all times in full force and effect.

\footnotetext{
11. Grantor shall have a say in types of trees to be planted
Also, Grantor would prefer to have warm weather grass in part of the $3 y$ acres.

$2^{\text {nd }}$ Day of April, 2004.
}

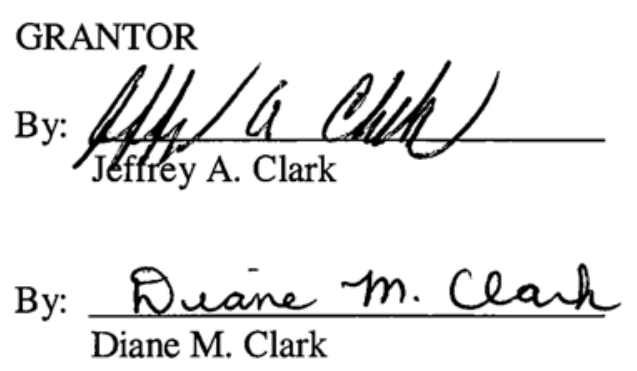

State Of West Virginia

COUNTy OF Preston_, to wit:

I, the undersigned, a Notary Public in and for the County and State aforesaid, do hereby certify that Jeffrey A. Clark and Diane M. Clark whose names as are subscribed above have signed the foregoing Access and Deed of Easement, have personally acknowledged, subscribed and sworn to the same before me in my aforesaid jurisdiction. 


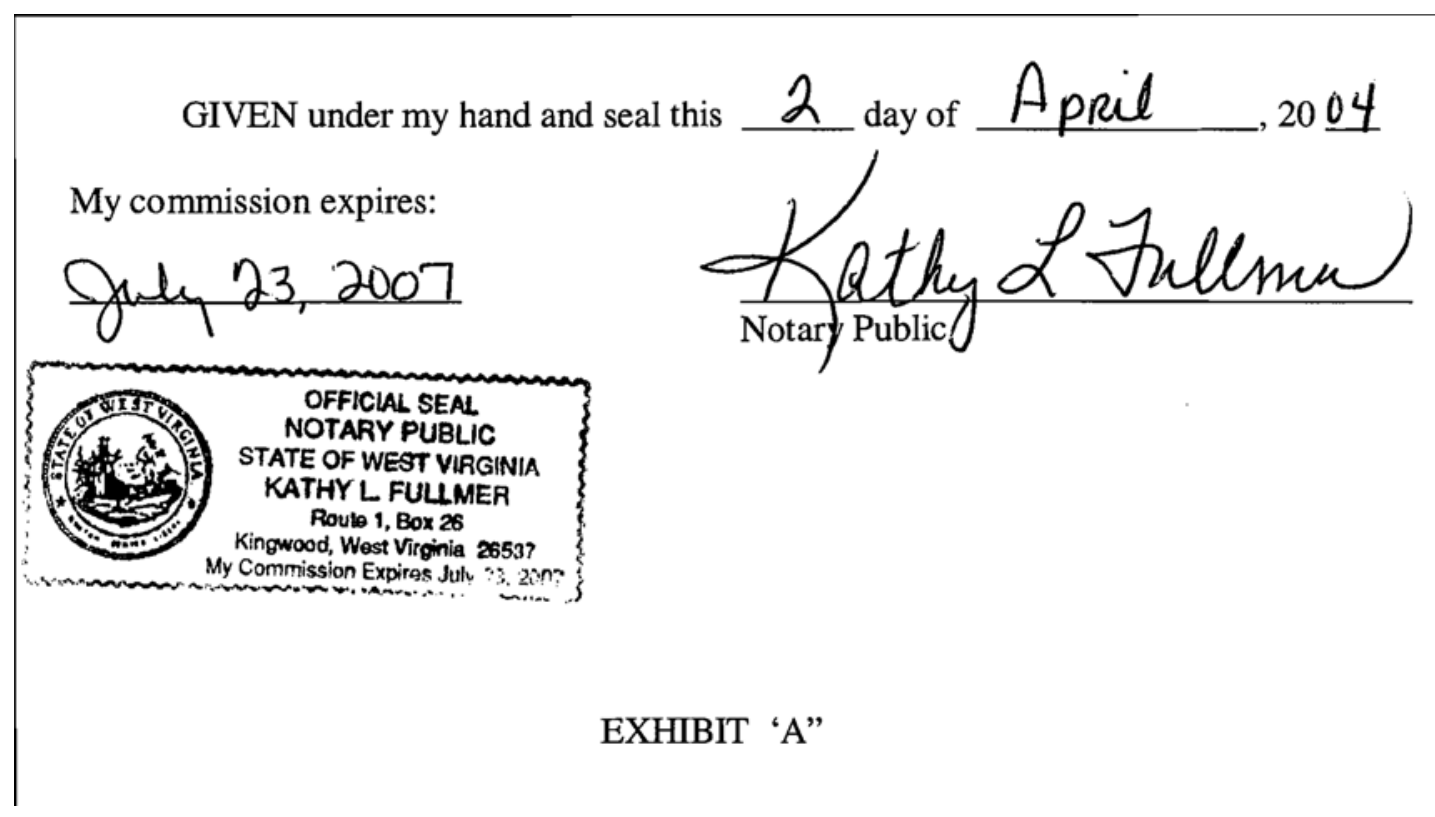

B-4 
Exhibit "A"

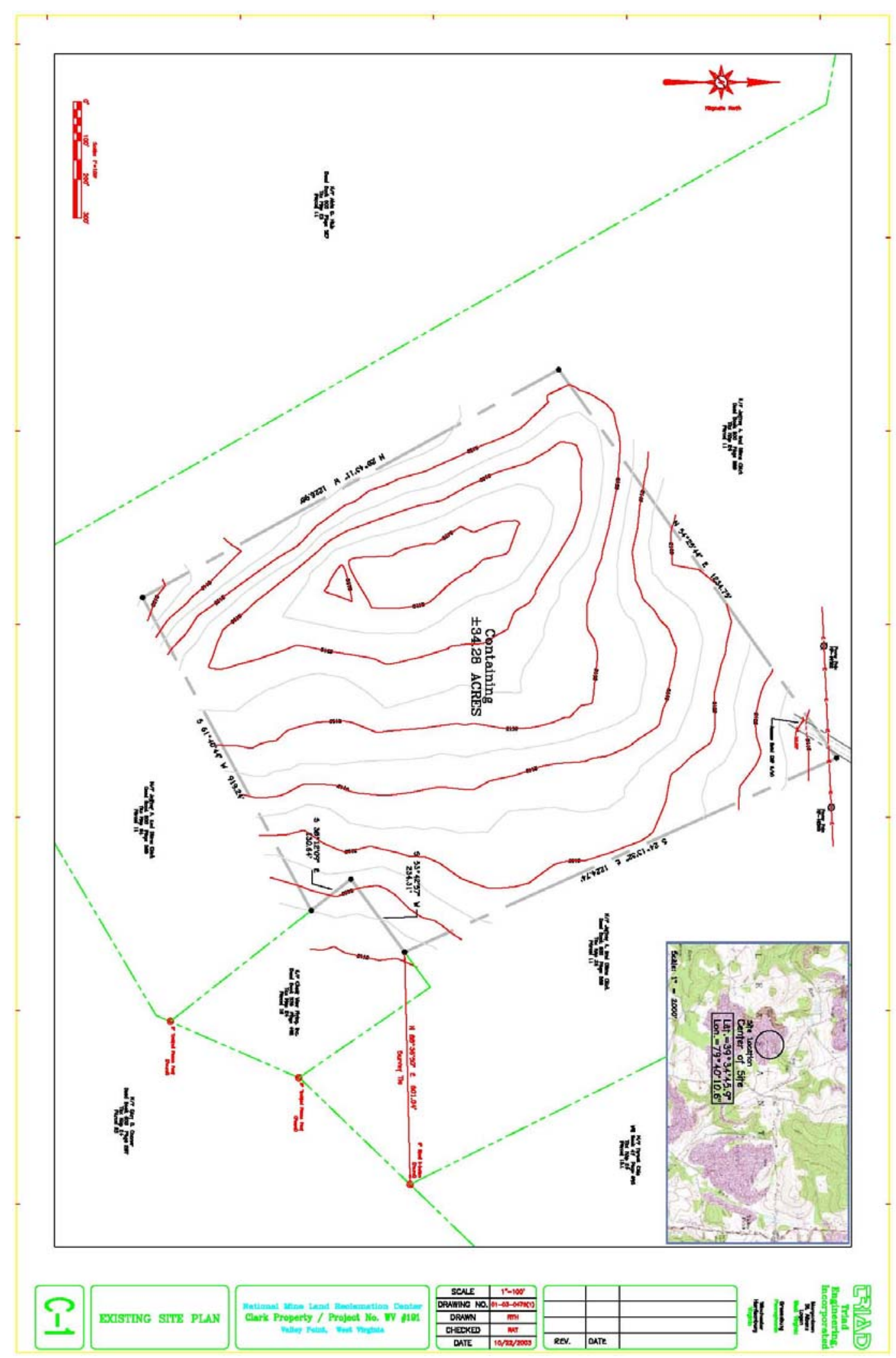





\section{PROCESS FOR CALCULATING AMOUNT OF ASH NEEDED TO NEUTRALIZE ACIDITY}

The following shows the process for calculating the amount of Albright Power Station ash needed to neutralize acidity at the Clark Farm site. Net Neutralization Potential (NNP) is presented in tons/1,000 tons expressed in $\mathrm{CaCO}_{3}$ equivalent.

\section{Inputs}

NNP, Albright Ash Units 1 and 3 (average of 13 samples)

NNP, Clark Farm Soil (25 acre test plot, average of 60 samples)

Ratio: $\mathrm{NNP}_{\text {soil }} / \mathrm{NNP}_{\text {ash }}$

Ash requirement per acre: $0.291 \times 1,000$ tons (a six-inch layer of soil covering one acre weighs 1,000 tons).

Test plot area

Ash requirement (25 acres x 291 tons/acre)

Design factor (wastage, etc.)

Total ash required (7275 x 1.05)

\section{Result}

4.724 tons/1000 tons $\mathrm{CaCO}_{3}$ equivalent

-1.375 tons/1000 tons $\mathrm{CaCO}_{3}$ equivalent

0.291

291 tons/acre

25 acres

7,275 tons

$5 \%$

7,640 tons 



\title{
TREE SEEDLING AND PLANTING BID SHEET
}

\author{
Richard Herd \\ National Mine Land Reclamation Center \\ West Virginia University \\ 150 Evansdale Dr. \\ P O Box 6064 \\ 202B NRCCE \\ Morgantown, WV 26506-6064 \\ Ph: 304-293-2867 X 5442 \\ Fax: 304-293-7822 \\ Email: rsherd@mail.wvu.edu
}

Please provide a firm price bid for the following 12-18” bare root tree seedlings and:

- Include a separate cost for delivery to Valley Point, WV (Preston County, approximately 8 miles south of U.S. Route 68 at Bruceton Mills exit).

- Also, include a cost for planting (if you provide this service) 25 acres on 6 foot spacing at the end of April-early May, 2005.

\begin{tabular}{|l|l|l|l|l|}
\hline Species & quantity & size & Cost/seedling & Total \$ \\
\hline White oak & 6,100 & & & \\
\hline White ash & 6,100 & & & \\
\hline Black cherry & 6,100 & & & \\
\hline Chestnut oak & 6,100 & & & \\
\hline Yellow Poplar & 6,100 & & & \\
\hline Total \$ & & & & \\
\hline
\end{tabular}

Delivery Charge: $\$$

Planting Cost: $\quad \$$

Please submit your cost/bid by January 28, 2005 to the address above. 



\section{TREE SEEDLING PLANTING QUOTE}

\section{Williams Forestry \& Associates}

P.O. Box 1543, Calhoun, Ga. 30703 706-629-0353 Fax: 706-625-0134

January 17, 2005

Mr. Richard S. Herd

National Mine Land Reclamation Center

West Virginia University

202B NRCCE 150 Evansdale Drive

PO Box 6064

Morgantown, WV 26506-6064

Dear Mr. Herd:

Proposal: To hand plant 39,000 seedlings at locations to be designated by WVU. We will provide a 12 man crew with two supervisors. Estimated time to complete this project is 2-3 working days. We will provide the following seedlings:

\begin{tabular}{lr} 
Species & Qty. \\
White Oak & 6,500 \\
N. Red Oak & 6,500 \\
White Ash & 6,500 \\
Black Cherry & 6,500 \\
Chestnut Oak & 6,500 \\
Yellow Poplar & 6,500 \\
\hline Total & 39,000
\end{tabular}

Seedlings will be 1-0 stock. The size of the seedlings will be 12-18 inches except for white oak which will be 10-18 inches.

Price: Total cost for seedlings and labor is $\$ 23,400.00$.

Thank you for the opportunity to provide a quote. Please call me if you have any questions. 



\section{$\boldsymbol{F}$}

\section{NOTICE TO CEASE WORK}

\section{WestVirginiaUniversity}

West Virginia Water Resources Research Institute

April 20, 2005

Mr. Dennis Clark

Tumbleweed Enterprises

RR 1, Box 100

Albright, WV 26519

RE: Request to cease all work for Purchase Order \#50031506

WV 191b Reforestation, Co2 Sequestration Enhancement and AMD

Treatment Design and Installation on Surface Mined Land in West

Virginia

Dear Mr. Clark:

The Electric Power Research Institute (EPRI) Project Manager has requested that you cease all work on the subject purchase order with West Virginia University (WVU).

The U.S. Department of Energy (DOE) has requested a project review meeting with EPRI and WVU on May 10, 2005 to discuss project status and future schedule. Following this meeting I will contact you to review the construction schedule and funding.

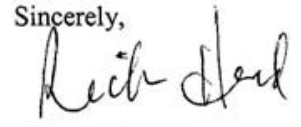

Rick Herd,

Program Coordinator

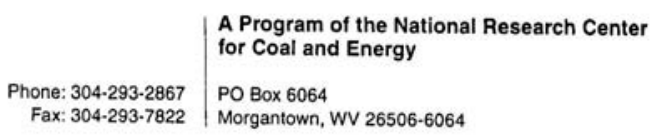

Equal Opportunity/Affirmative Action Institution 



\section{G STORM WATER PERMit NOTICE OF TERMINATION}

January 23, 2006

WV DEP -DWWM

Permitting and Engineering Branch $60157^{\text {th }}$ Street SE

Charleston, WV 25304-0495

Subject: Notice of Termination Permit WVR 100639

Dear Sir or Madam:

Please find enclosed a Notice of Termination for the above permit.

This permit was issued for Phase III of a research project "Demonstrating Market-Based Approaches for Mine Land Reclamation" funded by the Department of Energy (DOE).

Phase III of the project was terminated by DOE, which would have involved the planting of hard wood species for carbon sequestration. Prior to termination, approximately fifteen (15) acres, of the approximately thirty-five (35) acre project site, was cleared of undesirable 1"- 4" locust trees in the fall of 2004. During a fall 2005 site visit by the EPRI contractor (WV Water Research Institute), it was observed that locust is resprouting from roots with the site returning to its original condition.

Please have Mr. Bill Timmerneyer, of your office, call me at his earliest convenience to arrange for a site visit (202-293-7516).

Thank you.

Sincerely,

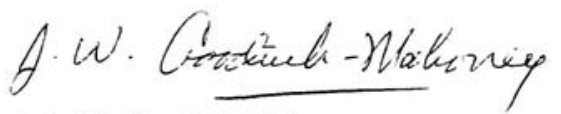

John W. Goodrich-Mahoney

Senior Project Manager

Environment Department

Enclosure

Cc: Richard Herd, WV Water Research Institute, w/o encl.

WASMINGTON OFFICE

2000 L Street. NW Ste 805 | Washington DC 20036 USA | 202.8729222

COAPORATE MEAOQUAATERS

3412 Hillview Avenue | Paio Alto CA 94304-1395 USA | 650855.2000 | Customer Service 800.313 .3774 | www.epri.com 



\section{$\boldsymbol{H}$ REFERENCES}

${ }^{1}$ EPA - United States Environmental Protection Agency, "Method for the Chemical Analysis of Water and Waste,” EPA 600/4-79-020.

${ }^{2}$ Standard Methods for the Examination of Water and Wastewater, $18^{\text {th }}$ Edition.

${ }^{3}$ Keefer, R.F., R.N. Singh, O.L. Bennett, and D.J. Horvath. 1983. "Chemical Composition Of Plants and Soils From Vegetated Mine Soils." In Proceeding of the 1983 Symposium for Surface Mine Hydrology, Sedimentology, and Reclamation. University of Kentucky, Lexington, Kentucky, USA.

${ }^{4}$ Capp, J.P. 1978. "Power Plant Fly Ash Utilization For Land Reclamation in Eastern United States." In Reclamation Of Drastically Disturbed Lands, edited by F.W. Schaller and P. Sutton. Madison, Wisconsin, USA: American Society of Agronomy, Inc.

${ }^{5}$ Bhumbla, D.K. 1991. “Ameliorative Effect of Fly Ashes.” Ph.D. dissertation. West Virginia University, Morgantown, West Virginia, USA.

${ }^{6}$ Singh, R.N., D.K. Bhumbla, R.F. Keefer, and D.J. Horvath. 1992. “Improving Crop Production By Altering Chemical Properties Of Mineland With Industrial Wastes.” In Proceedings of the International Symposium on Nutrient Management, edited by M.S. Bajwa and P.S. Sidhu. Punjab Agricultural University, Ludhiana, India. 366-380.

${ }^{7}$ Dhaliwal, S.S., R.N. Singh, D.K. Bhumbla, P. Saini, and R.F. Keefer. 1995. "Effects of Weathering On Trace Metal Distribution In Fly Ash Amended Mine Soils.” In Proceedings of the $11^{\text {th }}$ International Symposium On Use and Management Of Coal Combustion By-Prodcts (CCBs), Vol. 2, Orlando, Florida. American Coal Ash Association, Washington, DC, and Electric Power Research Institute, Palo Alto, California, USA. 57-1 to 57-11.

${ }^{8}$ West Virginia Department of Forestry, Cooperative Forest Legacy Program, “Conservation Easement Fact Sheet,” http://www.wvforestry.com/Easement\%20Fact\%20Sheet.pdf

${ }^{9}$ Parizek, R.R., 1986, Use of waste products to reclaim strip mined lands, In: Innovative Approaches To Mined Land Reclamation, C.L. Carlson and J.H. Swisher, eds., Southern Illinois University Press, Carbondale and Edwardsville, IL, pp. 223-281.

${ }^{10}$ Daniels, W.L., B. Stewart, K. Haering, and C. Zipper. 2002. “The Potential for Beneficial Reuse of Coal Fly Ash in Southwest Virginia Mining Environments”. Publication No. 460-134, Virginia Cooperative Extension. Virginia Polytechnic and State Univ., Blacksburg, Va. 
11 Ziemkiewicz, P.Z. 2004. "Use of Coal Ash for Mine Reclamation”. Coal Utilization Technologies Workshop. 2004. Morgantown, WV.

${ }^{12}$ White, W.B., ed. 2004 “Coal Ash Beneficial Use in Mine Reclamation and Mine Drainage Remediation in Pennsylvania”. Pennsylvania Department of Environmental Protection, 5600UK_DEP3132.

${ }^{13}$ Burger, J.A. and C.E. Zipper. 2002. "How to Restore Forests on Surface-Mined Land”. Virginia Cooperative Extension, Publication No. 460-123. Virginia Polytechnic Institute and State University. http://www.ext.vt.edu/pubs/mines/460-123-123.html 